$$
\begin{array}{r}
\text { Pontifícia Universidade Católica } \\
\text { do Rio de Janeiro }
\end{array}
$$

LAURA DE ASSIS SOUZA E SILVA

\title{
Dois mergulhos na prosa contemporânea: Daniel Galera, Carol Bensimon e o realismo íntimo
}

Tese apresentada ao Programa de Pós-Graduação em Literatura, Cultura e Contemporaneidade da PUCRio como requisito parcial para obtenção do grau de Doutor em Letras/Literatura, Cultura e Contemporaneidade.

Orientador: Prof. Karl Erik Schollhammer 


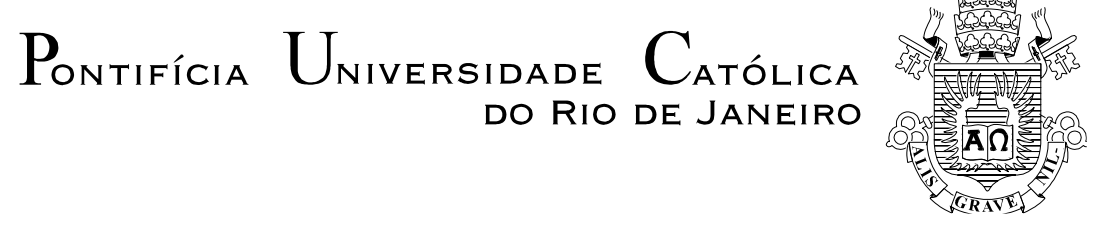

LAURA DE ASSIS SOUZA E SILVA

Dois mergulhos na prosa contemporânea: Daniel
Galera, Carol Bensimon e o realismo íntimo

Defesa de Tese apresentada como requisito parcial para obtenção do grau de Doutor pelo Programa de Pós-Graduação em Literatura, Cultura e Contemporaneidade do Departamento de Letras do Centro de Teologia e Ciências Humanas da PUC-Rio. Aprovada pela Comissão Examinadora abaixo assinada.

\author{
Prof. Karl Erik Schollhammer \\ Orientador \\ Departamento de Letras - PUC-Rio \\ Prof. Júlio Cesar Valladão Diniz \\ Departamento de Letras - PUC-Rio \\ Profa. Lia Duarte Mota \\ Prof. Alexandre Graça Faria \\ UFJF \\ Prof. Anderson Pires da Silva \\ UFJF \\ Profa. Monah Winograd \\ e Ciências Humanas - PUC-Rio
} Coordenadora Setorial do Centro de Teologia

Rio de Janeiro, 20 de abril de 2017. 
Todos os direitos reservados. É proibida a reprodução total ou parcial do trabalho sem autorização da universidade, da autora e do orientador.

\section{Laura de Assis Souza e Silva}

Graduou-se em Letras pela Universidade Federal de Juiz de Fora em 2008 e obteve o grau de Mestre em Estudos Literários na mesma instituição, em 2011. Publicou artigos, resenhas, textos poéticos e de ficção em diversas revistas, jornais, sites e antologias. É autora dos livros Depois de rasgar os mapas (Aquela Editora, 2014) e Todo poema é a história de uma perda (Edições Macondo, 2016). Atua como assistente de orientação no Mestrado em Gestão e Avaliação da Educação Pública (CAEd/UFJF) e coordena a Aquela Editora, selo dedicado à publicação de poesia contemporânea e de ensaios na área de humanas.

Ficha Catalográfica

Silva, Laura de Assis Souza e

Dois mergulhos na prosa contemporânea: Daniel Galera, Carol Bensimon e o realismo íntimo / Laura de Assis Souza e Silva; orientador: Karl Erik Schollhammer. $-2017$.

$106 \mathrm{f.} ; 30 \mathrm{~cm}$.

Tese (doutorado) - Pontifícia Universidade Católica do Rio de Janeiro, Departamento de Letras, 2017.

Inclui bibliografia

1. Letras - Teses. 2. Realismo íntimo. 3. Novos realismos. 4. Contemporaneidade. 5. Stimmung. I. Schollhammer, Karl Erik. II. Pontifícia Universidade Católica do Rio de Janeiro. Departamento de Letras. III. Título. 


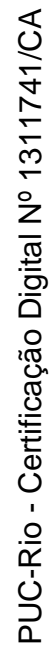

Para Mônica, que iluminou os dias mais escuros deste percurso. 


\section{Agradecimentos}

Karl Erik Schøllhammer, pela confiança e liberdade ao longo da orientação, pelas indicações precisas e pelos tantos escritos de sua autoria que vieram antes dessa tese e possibilitaram que ela existisse.

Anderson Pires, pelas leituras e sugestões desde a época do mestrado. Lia Duarte Mota, pelas inúmeras conversas e leituras, sobre a tese e sobre a vida, e por ter um dia me dado o Mãos de cavalo de presente. Alexandre Faria, um dos responsáveis pelo meu interesse por literatura contemporânea. Júlio Diniz, pelas contribuições com o projeto ainda na disciplina de Seminário de Tese. E aos quatro por aceitarem o convite para compor a banca de defesa, agradecimento que também estendo a Maria Luiza Scher e Fred Coelho.

Stefania Chiarelli e Renato Cordeiro Gomes, pelos comentários, críticas e sugestões no exame de qualificação, que me ajudaram a redefinir este trabalho a partir de outra perspectiva.

Larissa Andrioli, pela revisão, abstract e pelas várias ideias trocadas ao longo da escrita dessa tese, sobre o corpus e sobre a teoria.

Rodrigo Pinheiro e Daniele Cruz, pela ajuda imprescindível em várias questões burocráticas ao longo desses quatro anos.

Ao $\mathrm{CNPq}$ e à PUC-Rio, pelos apoios financeiros que tornaram este trabalho possível. 


\section{Resumo}

Silva, Laura de Assis Souza e; Schollhammer, Karl Erik. Dois mergulhos na prosa contemporânea: Daniel Galera, Carol Bensimon e o realismo íntimo. Rio de Janeiro, 2017. 106p. Tese de doutorado - Departamento de Letras, Pontifícia Universidade Católica do Rio de Janeiro.

O objetivo da tese é analisar na prosa contemporânea, dentro das propostas realistas que têm sido recorrentes na literatura brasileira, uma vertente que vem sendo denominada como realismo íntimo. A hipótese é de que autores cujas obras se inscrevem dentro dessa linha de força que vem se apresentando na novíssima literatura brasileira, como Daniel Galera e Carol Bensimon, buscam possibilidades de escrita que vão além da representação e descrição de espaços, situações e indivíduos, almejando a construção de uma narração e ambientação que transcenda a simples simulação de uma realidade física, usando, para tanto, estratégias distintas, que fazem com que o exterior atue, ao mesmo tempo, como reflexo interior e elemento revelador do universo íntimo dos personagens. No realismo íntimo, é a intimidade que constrói os cenários e, simultaneamente, é a partir do contato com o fora que se desvela o interior desses personagens. A partir da leitura e análise dos textos de ficção e de dispositivos teóricos tão contemporâneos quanto as próprias obras literárias em questão, o que se pretende é compreender as estratégias narrativas utilizadas, analisando de que modo o realismo íntimo se aproxima ou se distancia de outras abordagens relacionadas a uma (im)possível representação da realidade, assim como investigar sua correlação com a tradição realista que pode ser identificada em diferentes momentos da literatura brasileira.

\section{Palavras-chave}

Novos realismos; Realismo íntimo; Contemporaneidade; Stimmung. 


\section{Abstract}

Silva, Laura de Assis Souza e; Schollhammer, Karl Erik (Advisor). Two dives in the contemporary prose: Daniel Galera, Carol Bensimon and the intimate realism. Rio de Janeiro, 2017. 106p. Tese de doutorado Departamento de Letras, Pontifícia Universidade Católica do Rio de Janeiro.

The aim of this thesis is to investigate in the contemporary prose, within the realistic proposals that have been recurrent in the Brazilian literature, a field that has been called intimate realism. The hypothesis is that authors whose works fit within this line of force that has been presented in the latest Brazilian literature, such as Daniel Galera and Carol Bensimon, seek possibilities of writing which go beyond the representation and description of spaces, situations and individuals, aiming the development of realistic narrative and setting, transcending the simple simulation of a physical reality, using different strategies to achieve this strategies which make possible that the exterior operate at the same time as a reflection of the interior and a revealing element of the inner universe of the characters. The intimate realism is the one in which intimacy builds the scenarios and the contact with the outside world reveals the interior of the characters. From the reading and analysis of the texts of fiction and theoretical devices as contemporary as the literary works in question, the objective is to understand the narrative strategies used, analyzing how intimate realism approaches or distances itself from other approaches related to a(n) (im)possible representation of reality, as well as to investigate its correlation with the realistic tradition that can be identified in different moments throughout Brazilian literature.

\section{Keywords}

New realism; Intimate realism; Contemporaneity; Stimmung. 


\section{Sumário}

Introdução - Alguns motivos para mergulhar

1. De onde pular, para onde nadar 16

1.1. Algumas perspectivas do real na arte e na 17 literatura

1.2. A tradição realista na literatura contemporânea 21

1.3. O insistente retorno 24

1.4. O quarto retorno e algumas tipologias possíveis 26

1.5. Um realismo íntimo? 31

2. O primeiro mergulho 36

2.1. A procura de uma voz e o ensaio de um estilo: 40

Dentes Guardados e Até o dia que o cão morreu

2.2. Mãos de cavalo: descrever, sentir, enxergar 47

2.3. Barba ensopada de sangue: o nadador leva nos 54 ombros o narrador

2.4. A tecnologia da intimidade em Meia noite e vinte

3. O segundo mergulho 69

3.1. A arquitetura interior de Pó de parede 72

3.2. Sinuca embaixo d'água e a protagonista que não 79 estava lá 
3.3. A dupla viagem de Todos nós adorávamos 86 caubóis

4. Uma espécie de emersão 98

5. Referências bibliográficas 103 
O exterior não é uma antiga intimidade perdida na sombra da memória?

Gaston Bachelard

Que ninguém nos ouça: guarda esse escafandro, meu filho. Só o raso é cool. A dor é kitsch.

Paulo Henriques Britto 


\section{Introdução - Alguns motivos para mergulhar}

A controversa, intricada e dificilmente definível relação entre a arte e o que entendemos como realidade há muito tempo me chama atenção de um modo que, inicialmente, me parecia estar ligado apenas a uma predileção, que eu percebia estar presente não só nos livros, mas também nos filmes, peças e quadros que eu elegia como preferidos em diferentes momentos da vida. Entretanto, essa inclinação, que eu acreditava ser (e talvez, de início, realmente tenha sido) apenas um gosto, um favoritismo impressionista, acabou me guiando também ao longo das minhas incursões acadêmicas.

Ainda na graduação comecei a ler e estudar mais sistematicamente a obra do escritor carioca Sérgio Sant'Anna, atentando principalmente para aspectos relativos ao confronto entre realidade e ficção e à metaficção, além de buscar ligações entre os contos e romances do autor e obras distintas que, de alguma forma, lidavam com temas similares, como os quadros de Edward Hopper e os filmes de Charlie Kaufman.

Essas leituras acabaram me direcionando para, em seguida, já no mestrado, desenvolver em minha dissertação ${ }^{1}$ uma análise que, em linhas gerais, se concentrava em investigar o modo como os processos sociais da contemporaneidade vêm modificando as relações entre arte e realidade e como isso vinha se manifestando na literatura brasileira contemporânea, projeto que surgiu justamente a partir da leitura de algumas das obras de Sérgio Sant'Anna.

Tratando de como essas mudanças se refletem especificamente dentro da literatura, apontei que era possível notar na prosa de ficção contemporânea alguns traços que apontam para uma tentativa de representação de algo que Walter Benjamin já havia observado, ainda na primeira metade do século XX, como forte característica da modernidade e que nomeou "empobrecimento da experiência".

\footnotetext{
1 A dissertação intitulada Experiência e representação na prosa de ficção brasileira contemporânea foi desenvolvida no Programa de Pós-Graduação em Letras: Estudos Literários da Universidade Federal de Juiz de Fora, sob orientação da Prof. Dra. Terezinha Maria Scher Pereira, e defendida em dezembro de 2011.
} 
Como observei e procurei ressaltar ao longo do trabalho, vários filósofos da atualidade, como Giorgio Agamben, Zygmunt Bauman e Gilles Lipovetsky, acreditam que esse fenômeno não se configura como um traço exclusivo da modernidade, mas sim que ele tem se intensificado na atualidade, algo que pode ser percebido nas artes e na sociedade em geral. $\mathrm{O}$ que me interessou na pesquisa foi, portanto, analisar de que modo o empobrecimento - também chamado de "esvaziamento" ou "precarização" - da experiência poderia estar fazendo com que a literatura procurasse, por meio de estratégias distintas, expressar esse fenômeno, causando, portanto, mudanças profundas no estatuto da narrativa.

Algumas características como a ausência de diegese e de clímax, a metaficção, a inércia, a desmaterialização da trama narrativa, a desficcionalização e a subversão da ficção podem ser observadas com frequência na produção literária atual, e o foco do trabalho foi, portanto, discutir de que modo essas estratégias se dispõem a representar a temática do esvaziamento da experiência na contemporaneidade.

Entre 2009 e 2011, busquei, portanto, ler e escrever sobre tudo isso, mais especificamente, sobre a metaficção na prosa brasileira contemporânea, encarando essa tendência como uma espécie de reação à precarização da experiência, analisando esse movimento nas obras do já citado Sérgio Sant'Anna, mas também estendendo a reflexão para outros autores, como Paulo Henriques Britto, Joca Reiners Terron e Antônio Xerxenesky. Dentro da obra desses escritores, fiz alguns recortes, analisando apenas livros de contos lançados a partir de 2005.

Depois da conclusão do mestrado, entretanto, e ao longo de 2012, outras questões começaram a surgir. Se a metaficção era uma possibilidade de representação daquilo a que chamamos contemporaneidade e se eu havia conseguido analisá-la detalhadamente naquele trabalho, por que não se debruçar sobre outros autores, procurando quais caminhos distintos eles haviam seguido e buscando compreender outras possibilidades de representação?

Foi pensando nisso que escrevi meu projeto de doutorado, procurando aprofundar a pesquisa e a reflexão e operando o movimento contrário ao geralmente empreendido por aqueles que dão prosseguimento à pesquisa do 
mestrado no doutorado: em vez de me concentrar mais especificamente em um ou outro aspecto, decidi me afastar, aumentar o zoom, procurando uma perspectiva mais ampla daquele assunto.

Eu já havia identificado, a partir de leituras e, principalmente, análises comparativas, aquilo que chamei inicialmente de três linhas de força principais na literatura brasileira contemporânea: a primeira ligada a uma literatura mais intimista, relacionada também com uma preocupação de estilo, notada principalmente na atenção dada, por exemplo, à elaboração imagética e sensitiva; a segunda linha voltada para questões que podem ser chamadas de sociais, com a representação de personagens e espaços tradicionalmente colocados à parte dos temas literários e a terceira linha caracterizada pelo movimento de questionamento direto do próprio papel da literatura, expresso principalmente por meio da metaficção e da metaliteratura.

A partir dessa definição, elaborei o roteiro de uma espécie de mapeamento dos novos escritores realistas, propondo, no pré-projeto, a análise de três autores de cada uma dessas linhas, totalizando, então, nove autores, muitos deles com uma produção bastante extensa.

Porém, antes mesmo do exame de qualificação, essa pretensão já começou a me parecer um pouco exagerada e, mais do que isso, desacertada, no sentido de que as questões mais fundamentais e necessárias da pesquisa poderiam acabar ficando um pouco pulverizadas em meio a tantos autores, obras e análises impressão essa que foi confirmada nos comentários dos membros da banca e do meu orientador naquela ocasião.

A partir daí me propus a reconfigurar o projeto, o que me fez retornar a alguns dos pontos iniciais, buscando entender o que realmente me movia neste trabalho e qual era a questão central que poderia estar se escondendo por trás desse vasto mapeamento que eu tinha proposto.

Compreendi que o que eu até então entendia como novos realismos era uma proposta muito geral, mais ligada à questão do que eu entendia como representação, algo como "falar sobre a realidade" ou "representar o real", ideias que começaram a me parecer um pouco vagas. 
A partir do necessário movimento de repensar esses problemas, foram se delineando outras questões que, apesar de estarem conectadas à proposta inicial do projeto de tese, apresentavam também novas possibilidades de reflexão a partir das análises de estratégias narrativas distintas, ligadas, mais especificamente, àquela primeira linha de força e a algumas de suas singularidades, tendência essa que, curiosamente, era a que me parecia menos nítida. Enquanto a segunda e a terceira linha estavam, para mim bem definidas - e eu as chamava, respectivamente, de realismo social e realismo metaficcional -, a primeira ainda estava pouco demarcada, abrangendo, na minha leitura, romances que iam da autoficção aos monólogos interiores do realismo psicológico.

Foi quando me deparei com a resenha de Karl Erik Schøllhammer do livro Barba ensopada de sangue, de Daniel Galera, publicada na Revista Cult em novembro de 2012, na qual ele citava o termo "realismo íntimo". Dois fatos me chamaram atenção: o primeiro foi que um dos adjetivos que eu costumava usar para definir essa primeira tendência que identifiquei era "intimista" e o segundo fato é que um dos autores que eu considerava representativos dessa linha era justamente Daniel Galera.

Entretanto, esse termo não era definido em detalhes na resenha e não encontrei nenhuma referência que remetesse diretamente a uma conceituação do realismo íntimo. Mas foi a partir daí que se abriu uma nova possibilidade e com base nessa percepção reelaborei o projeto, propondo uma abordagem distinta, com o objetivo de compreender o que seria o realismo íntimo, a partir da identificação das estratégias narrativas utilizadas por determinados autores, analisando de que modo esse realismo especificamente se aproxima ou se distancia de outras vertentes relacionadas a uma (im)possível representação da realidade, assim como investigar sua correlação com a tradição realista que pode ser identificada em diferentes momentos da literatura brasileira.

Para alcançar esse objetivo geral, o trabalho se desdobrou em movimentos distintos: inicialmente, no primeiro capítulo, analiso as relações entre arte e realidade, pensando, inclusive, nos retornos da estética realista e naturalista na literatura brasileira, buscando, ao longo dessas reflexões e ao final do capítulo, uma primeira conceituação do realismo íntimo. 
Em seguida, nos capítulos 2 e 3, a intenção é, a partir das ideias sobre o realismo íntimo levantadas no primeiro capítulo, analisar as estratégias mais específicas utilizadas pelos autores, buscando compreender como elas aparecem nas obras de dois escritores da literatura contemporânea brasileira que, na minha leitura, conforme detalharei mais à frente, podem ser consideradas como expoentes dessa tendência: Daniel Galera e Carol Bensimon.

A intenção é ler criticamente toda a obra de cada um desses escritores, dedicando um capítulo a cada um deles, nos quais será realizada uma análise detalhada que perpassará questões relacionadas a temas abordados, estratégias narrativas utilizadas, elementos realistas e características que podem vir a aproximar e distanciar as obras desses autores do que vem sido produzido por seus contemporâneos.

Por fim, como fundamento e justificativa possíveis para este estudo - além da questão mais evidente relacionada à intenção de descobrir em que medida essa tendência do realismo íntimo pode se constituir como uma potencial chave de leitura para compreender e analisar parte da produção literária brasileira do presente - é possível, em uma perspectiva mais ampla, observar, justamente, a importância de investigar de que modo a literatura contemporânea tem procurado ou não estar afinada criticamente com as questões de seu tempo e que, nesse sentido, eleger a literatura do presente como corpus é uma escolha que explicita a convicção na urgência de compreender como a literatura vem lidando com os desafios e singularidades da contemporaneidade.

Se a arte é um dos caminhos para se entender e apreender a humanidade e a sociedade, nada mais lógico do que nos debruçarmos, então, sobre os pormenores e especificidades do que está sendo produzido nos dias de hoje. 


\section{1 \\ De onde pular, para onde nadar}

Este primeiro capítulo tem como objetivo contextualizar algumas das principais questões que perpassam o trabalho, apresentando, inicialmente, uma espécie de abordagem mais geral do assunto, mas buscando, de modo gradual, chegar aos pontos fundamentais da tese. O que proponho aqui é um percurso que começa com uma visão mais ampla de um tema, como se estivéssemos, eu e os leitores desse texto, nos aproximando aos poucos da questão que se constitui, de fato, como o cerne da pesquisa.

Acredito que não faria sentido simplesmente trazer aqui, de imediato, a leitura e análise das obras do corpus, assim como teorias que podem contribuir para essa análise e as perguntas e respostas que podem vir a circundar o realismo íntimo, tema central da tese, sem antes situar a questão do realismo como um todo, ou seja, compreender algumas circunstâncias gerais e particulares nas quais ele se inscreve.

Isso se dá pelo fato de que o realismo íntimo, como colocado na introdução, é uma tendência que coexiste com várias outras tendências diversas da nossa literatura do presente que, por sua vez, estão diretamente filiadas a uma tradição realista que pode ser verificada na produção literária brasileira. Entretanto, apesar dessa literatura ser fortemente marcada pelo realismo, essa característica não é um privilégio nem uma peculiaridade de nossa produção. $\mathrm{O}$ que ocorre é que essa questão, também presente em outros sistemas e tradições artísticas e literárias, encontra, na literatura brasileira, uma espécie de insistência, como se a nossa literatura não conseguisse se livrar ou escapar dessa tendência.

Desse modo, não podemos tratar o realismo - e aqui uso o termo de forma geral, considerando tanto as manifestações do realismo histórico como os novos realismos, manifestações distintas entre si, em cujas diferenças me deterei mais à frente - como uma característica particular da literatura brasileira, mas, ao mesmo 
tempo, não é possível abordá-lo de forma totalmente desvinculada de um contexto muito mais amplo.

Iniciando este percurso, então, em um primeiro momento, busco discutir as relações entre arte e realidade dentro de uma perspectiva mais geral, analisando de que modo essa questão já esteve (e está) presente em diferentes momentos, lugares, estilos e tendências, procurando compreender como essa ligação se constitui, de modos distintos, como um tema essencial dentro da arte.

A seguir, o que pretendo é mapear, especificamente na literatura contemporânea, como a busca pelo real se apresenta, trazendo uma breve apresentação de casos que considero representativos nesse sentido. A partir disso, o que vai me interessar é colocar o foco mais diretamente na literatura brasileira, analisando justamente a tradição realista, seus retornos e reverberações ao longo da nossa história literária.

Ao final do capítulo, procuro elencar as diversas formas de realismo que têm sido identificadas e definidas na contemporaneidade, analisando-as em uma perspectiva de comparação, buscando semelhanças e diferenças, limitações e delimitações, para, enfim, chegar ao que seria um conceito de realismo íntimo, conceito este imprescindível para alcançar o corpus literário do trabalho de forma mais consistente, de modo a responder alguns dos questionamentos aqui levantados sobre o tema.

\section{1.}

\section{Algumas perspectivas do real na arte e na literatura}

O conceito de realidade poderia figurar como questão central em pesquisas de praticamente qualquer área; esse termo tão amplo que pode se referir, simultaneamente, ao meio em que estamos constantemente imersos, ao ponto a partir do qual enxergamos o mundo e ao próprio mundo que vislumbramos. 
E é possível que uma das questões mais decisivas para grande parte das análises, categorizações, definições e impressões relativas à arte e à literatura tenha sido, desde sempre, justamente o quanto elas se distanciam ou se aproximam daquilo a que chamamos realidade. Essas relações entre arte e representação sempre se constituíram como parâmetros e paradigmas que marcaram, e marcam, as discussões teóricas e até mesmo filosóficas, tendo o papel, inclusive, de delinear e até mesmo nomear as expressões artísticas em determinados períodos da história.

Entretanto, sempre que se reflete sobre oposição e a relação entre a realidade e a ficção, é quase que inevitável passar também pelo questionamento da própria definição e percepção da realidade. O que é, de fato, o real? O que pode ser chamado, indubitavelmente, de realidade? O que percebemos como real, em oposição àquilo que sabemos que foi criado, no sentido imaginativo da criação?

Este trabalho não tem o objetivo nem a pretensão de responder perguntas como essas, as quais têm sido, por séculos, objeto de estudo das mais diversas linhas filosóficas. De Platão a Heidegger, passando por Descartes e Kant, praticamente todos os nomes mais significativos da filosofia ocidental já se detiveram em questões que perpassam os conceitos de real e realidade, buscando definir, questionar, delimitar ou expandir os entendimentos possíveis sobre esse tema. Portanto, optei por entender aqui o tão controverso conceito de realidade a partir da definição de Nicola Abbagnano, em seu Dicionário de filosofia (1971), de acordo com a qual o termo "indica o modo de ser das coisas existentes fora da mente humana ou independentemente dela" (2007, p. 831).

Outro aspecto que podemos observar é até que ponto essa suposta realidade, completamente dissociada da ficção, de fato existe na arte de forma tão pura e autêntica. Ao mesmo tempo em que é possível identificar elementos e eventos reais na ficção, também estão presentes, naquilo que chamamos de real, características ficcionais e imaginativas como, por exemplo, nas narrativas jornalísticas e documentais. Portanto, talvez os limites entre realidade e ficção, quando pensamos em uma perspectiva da arte e da criação, sejam muito mais tênues e facilmente confundíveis do que o hábito maniqueísta nos sugere. 
As artes plásticas passeiam por essa questão das possíveis conexões entre arte e realidade em períodos distintos, marcando, demarcando e questionando os limites da representação: da emblemática frase de Gustave Courbet - "Eu não posso pintar um anjo porque nunca vi nenhum" - ao realismo cru e melancólico de Edward Hopper - que carregava na carteira a cópia de um verso de Goethe: "O começo e o fim de toda a atividade literária é a reprodução do mundo que me cerca por meio do mundo que está dentro de mim" -, passando ainda pelo clássico quadro de René Magritte, "La trahison des images" (1929), que ironiza justamente a irrealidade da representação de um objeto, apenas para escolher três exemplos significativos da presença dessa tensão entre arte e realidade ao longo da história. Vários períodos da história da arte são, inclusive, definidos e denominados de acordo com a relação e a distância que guardam ou não de uma intenção realista, como o próprio realismo, o surrealismo e o impressionismo, por exemplo.

Em um contexto mais atual, o trabalho de uma artista como a francesa Sophie Calle também exprime essa urgência do que é real, em seu sentido mais palpável, vívido e vivido, como na obra Prenez soins de vous $(2007)^{2}$, toda ela criada a partir de um email de rompimento que a artista de fato recebeu de um namorado e das respostas que 107 mulheres contatadas por Sophie deram ao email, por meio de textos, fotografias, músicas, vídeos, performances, entre outros, transformando um acontecimento íntimo em uma obra pública, que se tornou, inicialmente, uma exposição e, em seguida, um livro. Além desse, outros trabalhos da artista francesa também lidam com questões relacionadas à realidade e suas possibilidades de criação e recriação.

Nesse cenário contemporâneo, é interessante pensar também em obras relacionadas ao conceito de realidade aumentada ${ }^{3}$, que, por meio da tecnologia, unem fragmentos do mundo real com o virtual em tempo real. Exemplos de obras que fazem uso desse tipo de recurso são o "AR Korean Unification Project" -

\footnotetext{
2 "Recebi uma carta de rompimento por email que não soube responder. Era como se não fosse a mim destinada. Terminava com as seguintes palavras: Cuide bem de você. Tomei esta recomendação ao pé da letra. Pedi a 107 mulheres, escolhidas por sua profissão, seu talento de interpretar a carta sob um ângulo profissional. Analisá-la, comentá-la, interpretá-la, dançá-la, cantá-la. Dissecá-la, esgotá-la. Fazer-me compreender. Falar no meu lugar. Uma maneira de sentir o tempo do rompimento. No meu ritmo. Cuidar bem de mim". (CALLE, 2007)

3 "A realidade aumentada é um tipo de interface avançada que permite, ao usuário, ver, ouvir, sentir e interagir com informações e elementos virtuais inseridos no ambiente físico, através de algum dispositivo tecnológico". (KIRNER, 2010)
} 
obra na qual o artista americano Mark Skwarek usa a realidade aumentada para, em dispositivos móveis, modificar a fronteira entre as Coreias do Sul e do Norte, substituindo tudo que estivesse relacionado ao conflito por uma floresta, representando a possibilidade da reunificação - e o trabalho da companhia canadense Lemieux Pilon 4D Art - que se autointitula uma companhia artística multidisciplinar e mistura teatro, dança, música, performance e vídeo, colocando em cena objetos e atores reais e virtuais, que interagem em suas produções cênicas de formas distintas.

Quando passamos mais especificamente à literatura, é possível lembrar uma questão teórica clássica. De acordo com Antoine Compagnon, mimese seria o "termo mais geral e corrente sob o qual se conceberam as relações entre a literatura e a realidade" (2006, p. 97), ressaltando, porém, que:

\begin{abstract}
Uma série de termos coloca, sem nunca resolvê-lo inteiramente, o problema da relação entre o texto e a realidade, ou entre o texto e o mundo: mimèsis, evidentemente, termo aristotélico traduzido por "imitação" ou "representação", "verossimilhança", "ficção", "ilusão", ou mesmo "mentira", e, é claro, "realismo", "referente" ou "referência", "descrição". Basta enumerá-los para sugerir a extensão das dificuldades. (Compagnon, 2006, p. 98)
\end{abstract}

Muito da teoria da literatura gira justamente em torno dessas dificuldades citadas pelo autor, ligadas à definição desses termos e das semelhanças e diferenças entre eles. Entretanto, a questão mais diretamente ligada ao realismo é trazida por Compagnon páginas adiante, quando conclui que em uma literatura considerada realista o que temos são mundos ficcionais possíveis (p. 136), o que vai ao encontro da definição de Aristóteles, que valoriza a arte como representação do mundo, justamente devido à autonomia do processo mimético, entendendo que a literatura pode representar "o que poderia acontecer, quer dizer: o que é possível segundo a verossimilhança e a necessidade" (1966, p. 78). Nesse sentido, o realismo pode então ser considerado de acordo com a definição de Thomas Pavel em Universo da ficção (1988), trazida pelo próprio Compagnon, segundo a qual: 
Em muitas situações históricas, os escritores e seu público consideram como ponto pacífico que a obra literária descreve conteúdos que são efetivamente possíveis e têm relação com o mundo real. Essa atitude corresponde à literatura realista, no sentido amplo do termo. Considerando assim, o realismo não é, pois, unicamente um conjunto de convenções estilísticas e narrativas, mas uma atitude fundamental referente às relações entre o universo real e a verdade dos textos literários. Numa perspectiva realista, o critério de verdade ou falsidade de uma obra literária e de seus detalhes é baseado na noção de possibilidade (...) em relação ao universo real. (Pavel apud Compagnon, 2006, p. 136)

Em uma perspectiva historiográfica, é sabido que, no final do século XIX, o realismo histórico inaugura a urgência em escapar da artificialidade da estética romântica; após seu esgotamento, entretanto, a história relata o distanciamento da representação direta da realidade, encontrado em movimentos como o Simbolismo e, depois, em nuances distintas, na literatura moderna. Já no século XX, o neorrealismo retoma a preocupação realista, operando uma nova inversão na perspectiva da representação da realidade.

A partir das constatações teóricas, históricas e filosóficas e dos exemplos que procurei trazer nessas últimas páginas, uma pergunta capital se coloca então para este trabalho: qual tem sido o lugar do real na produção literária do presente?

\section{2.}

\section{A tradição realista na literatura contemporânea}

Em Realist Vision (2005), Peter Brooks, referindo-se inicialmente ao realismo do século XIX, afirma que o romance realista é parte de uma história que já teve um início e um fim, porém salienta que o impulso que motivou a criação do realismo continua na contemporaneidade, uma vez que "the realism becomes so much the expected mode of the novel that even today we tend to think of it as the norm from which other modes are variants or deviants" (Brooks, 2005, p. 5).

De fato, é interessante observar que alguns dos autores mais lidos, reconhecidos e premiados na literatura mundial nos últimos anos são justamente 
aqueles que trabalham detalhadamente, mesmo que de formas distintas, a presença do que conhecemos como realidade em suas obras.

Pensando nos escritores e nas obras literárias de ficção que mais reverberaram nos últimos tempos, é possível encontrar, de modos distintitos, um apelo que podemos considerar como realista, que vai da literatura realista, no sentido mais simples da verossimilhança, à tão falada autoficção, tendência que tem ficado cada vez mais em evidência nos últimos anos.

Nesse cenário da tradição realista, os exemplos são os mais variados possíveis: foi com Liberdade (2011), anunciado na época como um "indelével e profundamente comovente retrato do nosso tempo", que o norte-americano Jonathan Franzen foi alçado ao posto de "grande romancista americano" por alguns dos maiores veículos de comunicação de seu país. Entretanto, uma década antes, o autor já fazia uso de uma linguagem extremamente descritiva para construir, em As correções (2001), os detalhes da história de uma família dos EUA e sua passagem por um choque de valores e perspectivas em meio às mudanças do fim do século XX, recriando, em pormenores, não só as possíveis vivências de uma família em específico, mas um amplo panorama da sociedade da época, com seus dilemas e contradições.

Já o britânico Ian McEwan tem uma longa lista de romances que se aproximam do que podemos chamar de realismo psicológico, trazendo, entretanto, sempre à tona também questões econômicas, políticas e éticas da atualidade, como em Sábado (2005), Solar (2010) e A balada de Adam Henry (2014).

Mesmo seu romance mais recente, Enclausurado (2016), que parte de uma premissa absolutamente fantasiosa - o narrador do romance é um feto que, de dentro do útero da mãe, que está no nono mês de gravidez, inicia o livro com a improvável frase "Então aqui estou, de cabeça para baixo, dentro de uma mulher." (McEwan, 2016, p. 9) e, a partir disso, narra sua história até ali, sua visão e as mais distintas opiniões sobre o mundo que ainda não conhece - , tem um forte vínculo com a realidade. McEwan, inclusive, afirma ${ }^{4}$ que considera seu romance

\footnotetext{
${ }^{4}$ Em outubro de 2016, Ian McEwan esteve em Porto Alegre, participando como conferencista no projeto Fronteiras do Pensamento. Grande parte da fala do escritor girou em torno de questões relativas à presença, possibilidades e limitações do realismo em suas obras. Um resumo da
} 
realista, justificando que "uma vez que esta primeira premissa é aceita, todo o resto que eu faço, neste romance, está no universo de um mundo compartilhado que eu acho plausível”, o que de fato pode ser verificado na leitura do livro, que lida diretamente com aspectos e possibilidades inteiramente verossímeis.

Elementos reais aparecem de forma distinta na obra do norueguês Karl Ove Knausgård, recente fenômeno de público e crítica, que na série de romances intitulada Minha luta, composta por 6 volumes lançados originalmente entre 2009 e 2011, navega entre a autobiografia e a ficção, propondo um relato o mais próximo possível do real, mas que, inevitavelmente, lida com as inúmeras possibilidades da criação literária e da ficcionalização.

O pensamento de Beatriz Jaguaribe vai ao encontro de exemplos como esses, quando identifica na atualidade o que ela chama de "pedagogia da realidade", conceito definido como "o uso de estéticas realistas em várias modalidades e expressões como meio de ilustrar retratos da realidade contemporânea" (Jaguaribe, 2010).

De acordo com esse apontamento estão as observações de Vera Follain de Figueiredo, que analisa como determinadas produções artísticas do final do século XX e do início do século XXI podem ser entendidas como seguidoras de uma 'tendência para a busca do 'real como matéria bruta', acompanhada da rejeição do ficcional, que nos permite falar em um movimento de retorno a uma estética realista" (Figueiredo, 2010).

É claro que a tendência realista não é uma vertente absoluta e não é difícil encontrar na produção atual livros que são publicados sob denominações como alta fantasia, fantasia científica e ficção mítica, por exemplo, além da permanência do realismo fantástico em alguns sistemas literários. Entretanto, se consideramos a reverberação - que se expressa não só no número de autores, mas também na combinação entre a existência de um grande público leitor e de um notável reconhecimento crítico, como é o caso dos três autores que usei apenas como uma

conferência pode ser encontrado no link: <http://www.fronteiras.com/resumos/em-busca-do-realpoa>. 
rápida amostra da tendência realista - dessa vertente, vemos que ela se apresenta como uma constante estética cuja intensa presença merece e precisa ser destacada.

\section{3.}

\section{O insistente retorno}

As questões referentes à ligação entre arte e realidade parecem ser, portanto, incontornáveis ao longo da história e presentes de forma marcante na atualidade e na literatura contemporânea de modo geral, conforme procurei mostrar nas seções anteriores. Entretanto, quando fazemos um recorte da literatura brasileira, é necessário atentar para o fato de que, nesse caso, temos um cenário no qual essa relação ocorre de forma ainda mais recorrente, o que confere ao caso determinadas especificidades.

Em Tal Brasil, qual romance? (1984), Flora Süssekind aborda essa questão de forma bastante detalhada, falando em uma espécie de persistência da estética realista e naturalista ${ }^{5}$ na prosa brasileira, apontando o realismo histórico do XIX, o romance de 30 e o romance documental dos anos 70 como expoentes dessa tendência, momentos aos quais a autora também se refere como "surtos naturalistas".

De acordo com Flora, até aquele momento, os retornos do naturalismo tinham sido analisados de forma isolada, no momento em que ocorriam, e não "como um sistema estético específico e dotado de certa continuidade, tão presente que, quando se faz necessário, torna-se possível recorrer imediatamente a ele" (Süssekind, 1984, p. 40).

Em uma analogia com a famosa afirmativa de Karl Marx presente em $O 18$ de Brumário de Luís Bonaparte (1852), baseada, por sua vez, em uma observação de Hegel, segundo a qual todos os fatos importantes da história se repetem, Flora

\footnotetext{
${ }^{5}$ Seguindo o que propõe Tânia Pellegrini no ensaio "Realismo: postura e método" (2007), optei por não me deter aqui nas diferenças entre as escolas realista e naturalista, uma vez que, assim como no texto citado, o que interessa mais especificamente neste trabalho são questões relativas ao método e às técnicas narrativas como um todo, e não aos detalhes que podem vir a distinguir as duas escolas.
} 
Süssekind aponta que esse movimento pode ser estendido também a fatos estéticos, como o Naturalismo, que, segundo ela, se repete na história da literatura brasileira "a primeira vez como estudos de temperamento, a segunda como ciclos romanescos memorialistas, a terceira como romances-reportagem" (Süssekind, 1984, p. 40).

A partir disso, o que Süssekind propõe então é um estudo dessa reincidência naturalista, buscando as continuidades e diferenças dessas repetições ao longo da história literária brasileira, assim como uma possível explicação para o que ela chama de uma "estabilidade" dessa estética. Ao longo de sua análise, Flora passa por questões principalmente ligadas ao dilema da identidade nacional, concluindo que:

[r]esta a repetição das tentativas quando, ao nosso gesto para alcançá-lo, sempre nos foge o objeto buscado. Por isso, como a um pai ou um objeto perdido, à dificuldade em restaurar os laços de uma impossível identidade, de uma cultura fraturada, correspondem as repetições naturalistas de um idêntico processo de reconstituição e captura da nacionalidade. (Süssekind, 1984, p. 45-46)

De fato, o realismo histórico - que, de acordo com Flora, foi "aproveitado pela cultura brasileira" e integrado às "necessidades ideológicas do país" buscou, por meio de uma adaptação da estética europeia, construir uma análise o mais próxima possível de uma abordagem científica, conforme os preceitos naturalistas da sociedade brasileira da época, como pode ser constatado nas obras de autores como Aluísio Azevedo, por exemplo.

Já o romance de 30, com Graciliano Ramos e Jorge Amado como seus maiores destaques, opera no sentido de trazer à tona questões econômicas e sociais da realidade brasileira, que naquele momento, de acordo com Flora, estavam "mais em sintonia com a trama histórica" (Süssekind, 1984, p. 86).

Sobre o romance-reportagem, levando em consideração o contexto político de ditadura, repressão e violência no qual esses romances surgiram, não é difícil identificar as características da "cultura fraturada" à qual Süssekind se refere. Silviano Santiago, inclusive, afirma que esses romances tinham como intenção 
principal "desficcionalizar o texto literário e com isso influir, com contundência, no processo de revelação do real" (Santiago, 1982, p. 52).

Pode-se observar, portanto, que essas três ocorrências da estética realista, apesar de guardarem semelhanças entre si, também se relacionam a partir de algumas diferenças fundamentais, conforme colocado pela autora.

A análise de Flora Süssekind em Tal Brasil, qual romance? chega até a literatura brasileira da década de 70; entretanto, como falado anteriormente, é possível verificar também na literatura contemporânea um insistente apelo realista. A partir disso, torna-se importante refletir sobre a presença dessa estética nos dias de hoje.

Sobre essa questão, especificamente, Paulo Tonani aponta que:

O modelo clássico do realismo histórico do século XIX serviu como ponto de partida, mas na observação da retomada do movimento, a cada volta realizada, é facilmente constatado o alargamento da experiência estética, que se expande e distancia do modelo. Dessa forma, os principais elementos estéticos do realismo do século XIX (...) passam a ser ressignificados e articulados a partir de uma nova configuração de realismo. (Tonani, 2012, p. 58)

Em consonância com essa afirmativa de Tonani está o comentário de Karl Erik Schøllhammer, de acordo com quem "os novos realistas querem provocar efeitos de realidade por outros meios" (2009, p. 54). E, a partir dessas observações, a pergunta que inevitavelmente se coloca no horizonte deste texto, que procura trabalhar justamente com manifestações realistas contemporâneas, portanto, é: que novas configurações e outros meios seriam esses?

\section{4 . \\ O quarto retorno e algumas tipologias possíveis}

A partir das leituras e considerações trazidas na seção anterior deste texto, é possível entender que existem novos e atuais conceitos que buscam analisar as 
manifestações realistas na contemporaneidade, que, por sua vez, podem ser entendidas a partir do modelo principal do realismo histórico do século XIX, mas sofrem modificações e alterações em relação a esse referencial.

Como colocado por Tonani e Schøllhammer, existem novos meios e novas configurações sob e por meio das quais se desenvolvem essas intenções realistas nas manifestações artísticas contemporâneas, ou seja, não estamos tratando aqui de uma simples repetição de estratégias ligadas ao realismo, que retornam exatamente do mesmo modo que ocorreram anteriormente na história literária.

Flora Süssekind identificou em sua análise do realismo histórico, do romance de 30 e do romance-reportagem da década de 70, que existem algumas semelhanças fundamentais entre os retornos realistas, embora as obras ligadas a cada uma dessas vertentes apresentem-se de maneiras muito distintas entre si. O mesmo ocorre com o que aqui estamos chamando de quarto retorno realista na literatura brasileira. Apesar de diretamente fundamentado em uma tradição realista, é possível observar grandes diferenças em relação ao modelo do realismo clássico, ou, nas palavras de Tonani, um "alargamento da experiência estética".

Esse termo, "alargamento", inclusive, pressupõe uma espécie de expansão do conceito. É como se, a cada retorno, o realismo fosse capaz de abarcar cada vez mais possibilidades, se apresentando de diferentes modos e usando estratégias distintas para concretizar o propósito realista de seus textos.

De fato, uma vez que tem sido possível identificar em grande parte da literatura contemporânea essa espécie de intenção realista, acabamos nos deparando com as mais variadas expressões artísticas e literárias que podem e vêm sendo chamadas de realistas, o que, por sua vez, tem resultado nas mais diversas definições dos chamados novos realismos, conforme procurarei delinear a seguir. A intenção é apresentar algumas das tipologias possíveis, com o intuito de elencar algumas das possibilidades que têm norteado as categorizações e análises das produções realistas que vêm sendo identificadas na contemporaneidade.

Um dos termos mais usados nos últimos anos, possivelmente, foi o de realismo traumático (também chamado de realismo extremo ou realismo de 
choque) proposto por Hal Foster em $O$ retorno do real (1996). O autor afirma que "há uma tendência a redefinir a experiência, individual e histórica, em termos do trauma", observando ainda que "para muitos, na cultura contemporânea, a verdade reside em temas traumáticos" (Foster, 2005, p. 185). Foster identifica uma mudança em relação ao efeito de representação para o que chama de "evento de trauma". Situando essa questão na narrativa brasileira contemporânea, Schøllhammer observa que

Tanto na indústria do entretenimento quanto na ficção literária e cinematográfica observa-se uma verdadeira "traumatofilia" que se tornou a forma heurística preferida de narrar o passado, uma procura do desastre inaugural (do qual todos de alguma maneira somos parte) que já não é o limite de toda experiência e identidade senão seu ponto de partida e o fundamento de sua possibilidade. De Bernardo Carvalho, Milton Hatoum, João Gilberto Noll e Cristóvão Tezza aos mais recentes Cecília Giannetti, João Anzanello Carrascoza e Michel Laub, a narrativa construída sobre a figura do trauma tornou-se a ficção psicanalítica preferida, pois permite que o incidente traumático pessoal remeta metonimicamente ao trauma da história e porque assim se justifica a necessidade de reconstrução da identidade individual numa identidade mais ampla, histórica, que o escritor trata de recuperar. (Schøllhammer, 2012, p. 23)

A partir dessas questões, Schøllhammer propõe então outra possível categoria de análise, o realismo afetivo, afirmando que as obras que de algum modo se aproximam dessa definição - e autores como André Sant'Anna, João Gilberto Noll e Ricardo Lísias figuram entre os exemplos - seriam textos que se descolam do realismo representativo, no sentido de criarem uma "suspensão da centralidade da representação, em favor de regras autônomas e rigorosas da realidade em construção", acabando por operar um movimento que, de certo modo, consegue "corromper ou diluir o confronto tradicional que marcou a crítica literária moderna: entre representação e expressão, imitação e imaginação, ou realismo e criatividade experimental (Schøllhammer, 2014).

No realismo afetivo, o efeito de realidade seria buscado ou encontrado não por meio de estratégias ligadas à representação dos modelos tradicionais, mas com a acentuação de "aspectos performáticos da escrita literária", como aponta Schøllhammer: 
Na prosa contemporânea o impacto afetivo não surge em decorrência do supérfluo dentro da descrição representativa, senão em consequência de uma redução radical do descritivo, de uma subtração na estrutura narrativa da construção sintática de ação e da preeminência da oralidade contundente do discurso em procura do impacto cruel da palavra-corpo. (Schøllhammer, 2014)

Outra categoria ligada aos novos realismos foi proposta em meados do ano 2000 pelo crítico norte-americano James Wood. No texto "Human, All Too Inhuman - on the formation of a new genre: hysterical realism", Wood apresenta o termo "realismo histérico" para se referir, de forma um tanto quanto negativa, ao que ele chama de um novo gênero literário que privilegia a construção de tramas complicadíssimas que, apesar de verossímeis, acabam se tornando pouco realistas devido à profusão de detalhes, coincidências e reincidências.

De acordo com Wood, o que se pode identificar em obras que seguem essa tendência não são histórias nas quais as pessoas, por exemplo, "desafiam as leis da física, mas sim histórias que desafiam as leis da persuasão" (Wood, 2000), o que faz com que essas tramas, apesar de possíveis, em uma perspectiva da verossimilhança, acabem se tornando muito pouco humanas. Ele afirma:

\begin{abstract}
Stories, after all, are generated by human beings, and it might be said that these recent novels are full of inhuman stories, whereby that phrase is precisely an oxymoron, an impossibility, a wanting it both ways. By and large, these are not stories that could never happen (as, say, a thriller is often something that could never happen); rather, they clothe real people who could never actually endure the stories that happen to them (...). And what above all makes these stories unconvincing is precisely their very profusion, their relatedness. (Wood, 2000)
\end{abstract}

Autores como Thomas Pynchon, Salman Rushdie, Zadie Smith e Don DeLillo foram apontados por Wood como autores cujas obras são exemplos desse realismo histérico, que seria caracterizado pelo que ele chama de "um medo do silêncio" e pela presença de inúmeras histórias e sub-histórias que apareceriam e reapareceriam, página após página, de modo que as convenções do realismo não são abolidas, mas, ao contrário, são “exauridas e sobrecarregadas” (Wood, 2000).

Tânia Pellegrini, por sua vez, dedicou vários textos a questões referentes a uma categoria que chama de realismo refratado, que consistiria na coexistência de 
técnicas de representação antigas e de heranças modernistas como fragmentação, estilização, colagem e montagem que, segundo a autora, traduziriam

Condições específicas da sociedade brasileira contemporânea: caos urbano, desigualdade social, abandono do campo, empobrecimento das classes médias, violência crescente, combinados com a sofisticação tecnológica das comunicações e da indústria cultural, um amálgama contraditório de elementos, gerido por uma concepção política neoliberal e integrado na globalização econômica. (Pellegrini, 2007, p. 138)

De acordo com Pellegrini, esse realismo pode ser entendido com "refração" por se apresentar de modos bastante distintos, "tanto nos temas como na estruturação das categorias narrativas e no tratamento dos meios expressivos" (Pellegrini, 2007, p. 139).

Já Paulo Tonani, em análise sobre a obra de Rubens Figueiredo, propõe uma discussão sobre o neonaturalismo, embasada em observações de Schøllhammer, segundo as quais "Continuando as experiências dos anos 1970, persiste hoje, sustentado pela sede de realidade geral, um certo neonaturalismo" (Schøllhammer, 2004, p. 223). Tonani questiona se esse neonaturalismo deve ser encarado como retorno - usando a expressão de Süssekind - ou como permanência - uma vez que Schøllhammer fala em uma continuidade -, mas conclui que a questão principal não seria essa definição e chama atenção para o fato de que "para reforçarmos o movimento de ancoragem ao passado e demarcarmos a contemporaneidade destas obras, estamos diante de um conjunto de obras que podem ser nomeadas como neonaturalistas" (Tonani, p. 268, 2013).

Entretanto, a obra de Rubens Figueiredo, especificamente, de acordo com Tonani, se situa no intervalo entre "o uso da tradição naturalista e a inserção de um novo referente", uma vez que o diálogo com o naturalismo clássico proposto no romance Passageiro do fim do dia não é baseado na utilização dessa estética, se constituindo de maneira semelhante

A um jogo de aproximação e afastamento, é mais amplo e tem como foco o próprio questionamento acerca do uso do naturalismo como ideologia para a tematização da realidade social brasileira. Na leitura do texto, soa claro que o autor não abarca 
o cientificismo da escola naturalista, ao contrário, coloca em tensão o lugar deste discurso e, principalmente, a vitalidade deste modelo de compreensão da sociedade. (Tonani, 2013, p. 270)

Desse modo, o que é identificado por Paulo Tonani é um outro tipo de estética realista, que existe justamente na tensão e, em alguns momentos, no movimento de distanciamento do neonaturalismo que, entretanto, não deixa de ser uma referência também nesse caso específico.

Existem ainda outras categorias relacionadas aos novos realismos, mas acredito que essa breve exposição já tenha sido capaz de mostrar o essencial: o fato de que existe uma profusão de nomes, nomenclaturas, rótulos e categorias colocadas e propostas a partir de um conceito maior, o de novos realismos, que buscam ler e analisar as diferentes manifestações das tendências realistas na contemporaneidade.

Isso explicita que, de fato, essa tendência como um todo tem um lugar muito significativo na produção atual, lugar esse que parece se ampliar cada vez mais. E uma prova disso é que mesmo nesse contexto, no qual já existem várias possibilidades de categorizações e designações, mais uma denominação surgiu recentemente, denominação essa que se distingue das que vinham sendo colocadas e recolocadas nos espaços da crítica a partir deste amplo conceito de novos realismos até então e que se relaciona a parte significativa da produção contemporânea: o realismo íntimo.

\section{5 .}

\section{Um realismo íntimo?}

Inicialmente utilizado nas artes plásticas e, posteriormente, retomado por Gerald Bruns para apontar determinadas especificidades da poesia moderna, o termo realismo íntimo foi revisitado em outro contexto por Karl Erik Schøllhammer, em uma resenha sobre o penúltimo romance de Daniel Galera, Barba ensopada de sangue (2012), destacando que o livro estaria próximo de 
"uma espécie de realismo íntimo", no qual a intimidade provém "da precisão descritiva dos cenários escolhidos e da empatia que sempre expressa com os humores do personagem" (Schøllhammer, 2012).

A denominação "realismo íntimo", portanto, é aqui utilizada buscando algo próximo da definição de um tipo de literatura que privilegia a relação do eu com o mundo, na sua acepção mais próxima da origem etimológica da palavra "íntimo": "o mais profundo" ou "o que atua no interior".

No mesmo texto, Schøllhammer afirma ainda que:

O que é interessante na narrativa de Galera é sua capacidade de criar uma visão convincente da realidade brasileira sem nenhum resquício dos eternos resgates de uma identidade histórica ou cultural e sem as tentações pitorescas e exóticas. Estamos no sul, em Santa Catarina e sem dúvida no contexto contemporâneo com características históricas claras e conflitos socioculturais rapidamente identificados. Criar personagens vivos em ambientes e enredos convincentes é a força fabuladora de Galera. (Schøllhammer, 2012)

A ausência desses "eternos resgates de uma identidade histórica ou cultural" marca uma forte distinção entre o realismo íntimo de Galera e as estéticas analisadas por Flora Süssekind. O que Schøllhammer aponta no romance é justamente um desprendimento da questão da identidade nacional, movimento que, de fato, vem marcando, de modos distintos, a literatura contemporânea, como é possível verificar na fala de Renato Cordeiro Gomes, de acordo com quem:

É lugar comum na historiografia da literatura e da crítica brasileiras afirmar o empenho (uma literatura empenhada, uma cultura empenhada) de nossas letras na busca de uma identidade cultural da Nação. O processo de diferenciação cultural da Nação relaciona-se a formas de representação que ganham a função políticoideológica enquanto traço articulador do projeto histórico de constituição dessa identidade (...) Parece, entretanto, que, nos últimos trinta anos, a Nação foi deixando de ser o centro de um sistema de significação, e as artes e a literatura, mesmo dramatizando assuntos locais, vão abrindo mão de representar o EstadoNação, ainda que algumas narrativas reciclem essa herança, enquanto resíduos para enfrentar o impasse de representar a Nação, mesmo tentando (ou impondo-se), de certo modo, interpretá-la. (Gomes, 2014, p. 22) 
O autor vai ao encontro do que é colocado por Stuart Hall, que afirma que o efeito geral dos processos sociais da contemporaneidade tem sido justamente enfraquecer as formas nacionais da identidade cultural. $\mathrm{O}$ deslocamento das ideologias estabelecidas para uma postura múltipla, multifacetada e dos grandes projetos para os projetos particulares, contribui para o que Hall chama de descentramento de identidades. Ele afirma ainda que "[e]xistem evidências de um afrouxamento de fortes identificações com a cultura nacional e um reforço de outros laços e lealdades culturais acima e abaixo do estado nação." (Hall, 1999, p. $73)$.

O que ocorre, portanto, é o que se pode chamar de uma desestabilização do conceito de nação. Na literatura brasileira contemporânea, especificamente, podese observar que não existe mais um grande projeto coletivo e homogêneo de nação que procure abarcar e representar o povo como um todo, e sim uma multiplicidade de projetos que trabalham justamente com as fronteiras, tensões e interseções inerentes à heterogeneidade da nação. Na literatura brasileira do presente, a nação não parece mais ser uma questão fundamental, pois ela não está mais no centro do sistema de significação, e o que se pode notar na produção literária de hoje é uma espécie de retração desse tema, antes tão presente em nossa literatura.

Entretanto, existem tendências contemporâneas realistas que lidam de outras formas com essa questão da identidade e da nação, trabalhando com o que Renato Gomes chama de "resíduos", buscando atualizar, em projetos distintos e formas heterogêneas, o desenrolar histórico do que um dia foi a ideia de nação.

No realismo íntimo, no entanto, essa não é uma questão - e acredito que essa característica seja um dos pontos que evidencia sua singularidade em relação a outras tendências realistas.

A minha hipótese é que o que aqui chamo de realismo íntimo, a partir da colocação de Schøllhammer, é uma tendência realista contemporânea que trabalha com possibilidades de escrita que vão além da representação e descrição de espaços, situações e indivíduos, almejando a construção de uma narração e ambientação que transcenda a simples simulação de uma realidade física, 
construção essa que se origina a partir de uma perspectiva muito subjetiva, de um narrador ou personagem, a partir da qual é delineada toda uma realidade verossímil, realidade (ou externalidade) essa que também é responsável por desvelar a intimidade desses personagens.

Essa intimidade está ligada também ao fato de que esse realismo, especificamente, se apresenta de forma muito descolada dos projetos realistas, anteriores e atuais, que de alguma forma estiveram ou estão vinculados a alguma preocupação relacionada à questão nacional, seja como construção ou desconstrução, desde o problema da delineação, afirmação e reafirmação de uma identidade, como aponta Süssekind, até as propostas mais atuais que de alguma forma lidam com tensões mais ligadas à realidade social, como os recorrentes retratos da violência urbana e das tensões sociais existentes nas grandes cidades, por exemplo.

Esse conceito vai ao encontro do que Tonani aponta a respeito do "alargamento da experiência estética realista" e aos "novos meios" citados por Schøllhammer, mas, por outro lado, se distancia de outras categorizações dos novos realismos já colocadas, devido, principalmente, ao fato de estar mais voltado para as tensões internas do indivíduo e para a subjetividade do que para as tensões sociais. No realismo íntimo, é a intimidade que constrói os cenários físicos e, simultaneamente, é a partir do contato com esses cenários que se desvela o interior dos personagens.

O que proponho a partir daqui neste trabalho é, portanto, buscar nas obras de dois escritores brasileiros contemporâneos indícios dessa tendência, ou seja, analisar de que modo essa vertente realista, que aqui chamo de realismo íntimo, vem sendo construída na nossa prosa de ficção, procurando, inclusive, a partir dessas análises, delinear as possibilidades, impressões e expressões dessa tendência na prosa de ficção brasileira que está sendo produzida no presente.

A escolha desses autores se deu, inicialmente, a partir do que em uma seção anterior deste trabalho chamei de reverberação, que seria, na minha leitura, uma combinação entre a existência de um público leitor e de certo reconhecimento 
crítico, além, é claro, de uma identificação inicial com as características do realismo íntimo conforme apresentado anteriormente.

Entretanto, na impossibilidade de desenvolver um trabalho que abarcasse a obra de todos os autores que poderiam vir a se aproximar dessas categorias préestabelecidas, busquei trabalhar com escritores que divergem nas estratégias utilizadas ou no modo como usam essas mesmas estratégias, mas que, entretanto, têm estilos convergentes, recorrendo a experiências narrativas similares ou, no mínimo, próximas.

Acredito que seja possível ainda identificar que, atendidas essas especificidades elencadas acima, a seleção do corpus foi norteada também por uma predileção, ou seja, uma questão pessoal de gosto, inclinação e interesse em relação às obras dos escritores escolhidos.

O que procuro apresentar a seguir, portanto, é justamente uma análise dessas estratégias ao longo das obras de Daniel Galera e Carol Bensimon, buscando compreender como as intrincadas relações entre a arte e a realidade, entre o real e a ficção, estão presentes nas páginas dos romances desses escritores e de que modo elas se articulam no sentido de definir e desdobrar as possibilidades do realismo íntimo, a partir do que foi discutido neste primeiro capítulo. 


\section{2 \\ O primeiro mergulho}

A partir das discussões sobre o realismo íntimo levantadas anteriormente, este segundo capítulo tem o objetivo de analisar a obra do escritor Daniel Galera, buscando compreender como determinadas características relacionadas a essa tendência, previamente apresentada no primeiro capítulo, têm aparecido, de formas distintas, em seus livros.

O que proponho aqui é uma leitura crítica da produção ficcional de Galera desde sua estreia em livro, em 2001, até sua publicação mais recente, de 2016 -, com a intenção de realizar uma análise detalhada dos textos, passando por questões relacionadas a temas abordados, estratégias narrativas utilizadas, elementos realistas e outras características que podem vir a fazer com que esses livros possam ser entendidos e lidos na chave do realismo íntimo, conforme conceituado no capítulo anterior.

Acredito que seja importante, entretanto, esclarecer que o objetivo não é rotular a obra do autor a partir desse conceito, apresentando uma leitura fechada, estática ou reducionista de seus escritos. As análises apresentadas se aproximam mais de uma tentativa de desdobramento de possibilidades de leituras ocasionalmente confrontadas com ideias de alguns teóricos contemporâneos que podem vir a iluminar alguns aspectos delas -, a partir das quais creio que será possível encontrar e reencontrar algumas perspectivas e, talvez, vislumbrar uma essência, uma espécie de projeto, guiado por determinadas linhas de força algumas delas relacionadas à hipótese central desse trabalho.

Minha intenção, portanto, não é traçar um percurso em linha reta ao longo da obra de Galera. Não proponho aqui um roteiro fechado, um trajeto preciso de encontro a um alvo pré-determinado. Prefiro comparar essa incursão a uma espécie de mergulho livre, que, apesar de ter um intuito inicial, pode também se deixar levar por outras forças, correntes e fluxos imprevistos. Tenho, claro, um 
norte, uma motivação fundamental para esse movimento, mas a ideia é que essa não seja uma limitação, e sim mais uma possibilidade.

Inicialmente, portanto, a título de apresentação, é necessário trazer algumas informações sobre a biografia do autor.

Daniel Galera nasceu em 1979 em São Paulo, mas foi criado em Porto Alegre, onde vive hoje, depois de alguns períodos nos quais residiu na capital paulista e em Santa Catarina, mais especificamente em Garopaba, uma pequena cidade do litoral catarinense, cenário que ele recria em detalhes no romance Barba ensopada de sangue (2013).

Entre 1997 e 2001, Galera publicou diversos textos na internet, inicialmente atuando como editor do site Proa da Palavra, um dos primeiros sites literários brasileiros, e, posteriormente, como colunista do mailzine Cardosonline ${ }^{6}$, conhecido como um veículo percussor da literatura na internet no país.

Após o fim do fanzine, em 2001, Daniel Galera fundou, ao lado de Daniel Pellizzari e Guilherme Pilla, o selo independente Livros do Mal, que publicou livros de autores como Joca Reiners Terron e Paulo Scott, além dos livros de estreia dos editores Galera e Pellizzari.

Foi também pela editora Livros do Mal que Daniel Galera publicou seu primeiro romance (frequentemente também apontado como uma novela, devido a sua curta extensão), Até o dia em que o cão morreu (2003), relançado em 2007 pela Companhia das Letras e adaptado para o cinema por Beto Brant e Renato Ciasca, no mesmo ano, com o título de Cão sem dono.

Pela Companhia das Letras também saíram os livros seguintes de Daniel Galera: Mãos de cavalo (2006), Barba ensopada de sangue (2012) e Meia noite e

\footnotetext{
6 "O CardosOnLine (COL) é um fanzine digital produzido em Porto Alegre e distribuído exclusivamente por e-mail. Escrito por um staff de 8 colunistas, com uma edição por semana, o COL trata de cultura alternativa, cinema, música, literatura, mídia e artes em geral, publicando também contos, crônicas, poesia e egotrips. Criado em Outubro de 1998, o fanzine já possui uma lista com mais de 4500 assinantes em todo o Brasil, e lotou o Garagem Hermética em suas 12 festas, os "Bailões". Conheça o COL, assine, leia e participe." (descrição que figurava no site que divulgava o Cardosonline na época de sua circulação, encerrada em outubro de 2001, e ainda pode ser encontrado no endereço: <http://www.geocities.ws/SoHo/Atrium/7830/index-2.html>)
} 
vinte (2016), além da graphic novel Cachalote (2010), ilustrada pelo quadrinista Rafael Coutinho.

Galera tem, ainda, uma sólida atuação como tradutor de língua inglesa, já tendo traduzido livros de autores como Irvine Welsh, Jonathan Safran Foer, Hunter S. Thompson, John Cheever, Jack London, Zadie Smith e David Foster Wallace - que ele afirma ser uma de suas maiores referências - e já atuou ainda como colunista do jornal $O$ Globo. Ocasionalmente publica resenhas, reportagens e outros textos, dentre os quais se destaca Virando o jogo (2010), um extenso ensaio sobre as possibilidades narrativas dos videogames, a partir da análise do jogo Prince of Persia.

É difícil precisar qual foi meu primeiro contato com a obra de Daniel Galera. Possivelmente por meio de uma descompromissada leitura online de alguns dos textos de seu primeiro livro, Dentes guardados - um volume de contos lançado em 2001, cuja versão impressa há muito já está esgotada, mas que circula pela internet em uma versão digital disponibilizada pelo próprio autor em 2004.

Mas me recordo que, em 2007, enquanto acompanhava o lançamento de todas as informações que saíam na imprensa sobre o polêmico projeto Amores Expressos $^{7}$ - que me despertava interesse, inicialmente, devido à participação de Sérgio Sant'Anna, autor que eu já estudava na época e que participou do projeto viajando para Praga e, posteriormente, em 2011, publicando o livro resultante da viagem, intitulado O livro de Praga: narrativas de amor e arte -, o nome de Daniel Galera entre os de vários escritores convidados para fazerem parte da iniciativa, como Adriana Lisboa, João Paulo Cuenca, Bernardo Carvalho, Chico Mattoso, Lourenço Mutarelli e Luiz Ruffato, entre outros, já não era, para mim,

\footnotetext{
${ }^{7} \mathrm{O}$ projeto Amores Expressos consistiu na seleção de 16 autores brasileiros, que foram enviados, cada um a uma capital do mundo, como Paris, Tóquio, Nova Iorque, Dublin e Havana, onde deveriam passar um mês. Depois disso, eles deveriam escrever um romance que contasse uma história de amor passada na cidade para a qual eles viajaram, livro este que seria publicado pela Companhia das Letras. O projeto contou também com a produção de 16 documentários, cada um cobrindo a estada de um dos autores, e blogs nos quais esses mesmos autores postavam suas impressões sobre a cidade para a qual foram enviados. A polêmica se deu principalmente devido à ausência de um critério claro de seleção dos autores, que obedecia apenas à preferência dos curadores do projeto, e devido à notícia de que os gastos do projeto - incluindo a viagem dos autores e uma ajuda de custo - seriam em parte financiados pela Lei Rouanet, o que acabou não acontecendo, tendo o financiamento do projeto ocorrido estritamente de forma privada, sem o incentivo fiscal desta lei. Dos 17 romances, 13 foram entregues pelos autores à editora, que recusou dois e publicou os outros 11, entre 2008 e 2013.
} 
um nome estranho, possivelmente devido a certa repercussão que o Cardosonline e a Livros do Mal alcançaram alguns anos antes, por meio de reportagens e resenhas em sites, revistas e jornais.

O livro de Galera, Cordilheira, foi o primeiro livro da coleção a ser publicado, em 2008, e também o primeiro romance que li do autor, no mesmo ano. Mesmo não tendo ficado particularmente impressionada com a leitura do livro, foi a partir desse momento que passei a acompanhar a carreira de Galera com mais atenção.

Apesar de não ser uma obra especialmente representativa do ponto de vista crítico, foi o romance encomendado pelo projeto Amores Expressos que me aproximou da produção de Daniel Galera, me despertando o interesse pela leitura completa de Dentes Guardados e Até o dia em que o cão morreu, obras publicadas por ele até então.

Porém, foi o contato com Mãos de cavalo que levou meu interesse pela obra de Galera a outro patamar, principalmente devido à complexidade da construção dos arcos narrativos e da narrativa em si e à maneira como o autor trabalha as estratégias ficcionais sempre dentro de uma perspectiva realista, questões que procurarei desenvolver de modo detalhado neste capítulo.

A partir dessa leitura, acompanhar a produção de Galera foi um movimento natural para mim, o que resultou na observação de que justamente os pontos que me chamaram atenção em Mãos de cavalo reaparecem de modos distintos nos livros de sua autoria que li posteriormente, Barba ensopada de sangue e Meia noite e vinte.

Apresentações feitas, o que proponho a partir daqui é uma análise da obra de Daniel Galera, seguindo uma ordem cronológica de suas publicações, iniciando, portanto, em Dentes guardados (2001) e culminando na leitura de seu romance mais recente, Meia noite e vinte (2016).

Ao longo dos 15 anos que separam essas duas publicações, o estilo de Galera sofreu algumas modificações, mas é interessante observar que a produção do autor vem se construindo a partir de uma chave essencialmente realista e o que 
vem ocorrendo é a intensificação de características e estratégias que se articulam justamente no sentido de refinar e diversificar os modos de realizar essa construção, conforme acredito que será possível perceber nas seções seguintes.

Entretanto, é necessária aqui uma ressalva: fiz a opção de não me deter em análises de duas publicações do autor, Cachalote e Cordilheira. A primeira, por ser uma história em quadrinhos, criada em parceira com um ilustrador, exigiria um tipo de abordagem muito distinta do que está sendo proposto nesta tese. Já a segunda, devido ao fato de ser um livro produzido sob encomenda, com tema e cenários pré-determinados pelo projeto Amores Expressos e pela editora - e, por isso, apesar de inevitavelmente apresentar características do estilo do autor, estar menos relacionada a escolhas estéticas mais específicas do que a demandas de mercado e publicação.

Apesar de esses aspectos poderem ser apresentados como possíveis preocupações latentes em qualquer obra - e não é possível precisar o peso exato disso dentro de nenhuma produção artística -, no caso de Cordilheira essas questões estão bastante explícitas. Não acredito que elas diminuam a importância da obra dentro da produção do autor, mas sim que situem o romance em um local de interesse um pouco distinto do que estamos tratando aqui, por isso essa opção.

Sendo assim, o foco do trabalho a partir de agora passa a ser os outros cinco livros de Galera: Dentes guardados (2001), Até o dia em que o cão morreu (2003), Mãos de cavalo (2006), Barba ensopada de sangue (2012) e Meia noite e vinte (2015) - e é na análise detalhada dessas obras que irei me deter daqui em diante.

\section{1.}

A procura de uma voz e o ensaio de um estilo: Dentes Guardados e Até o dia que o cão morreu

Com 14 contos, escritos entre 1998 e 2000, Dentes guardados é um livro que trabalha com temas distintos, mas se concentra em questões ligadas a 
relacionamentos, com várias narrativas que tratam, em geral, de problemas cotidianos, encontros e desencontros, conversas e acontecimentos triviais relacionados às vidas de personagens tão jovens quanto o autor do livro na época da escrita e publicação dos textos.

O livro recebeu alguma atenção crítica quando foi publicado, com resenhas de Bernardo Carvalho na Folha de São Paulo e Paulo Roberto Pires na revista Época. Enquanto o primeiro se atém mais na análise de um conto específico, "Triângulo", observando que Galera "se serve do estilo que pretende chegar mais perto da realidade" e se revela como "um escritor estreante com consciência dos poderes subjetivos da literatura", o segundo observa que os contos são atravessados "por referências ao cotidiano de jovens intelectualizados e saudavelmente insatisfeitos com a vida".

Em Dentes guardados ainda não é possível identificar uma das principais marcas da literatura de Galera: o empenho descritivo, direcionado, principalmente, para a construção de cenários e personagens. Não existe, neste livro, um trabalho muito denso com relação ao desenvolvimento dos personagens - à exceção, talvez, do último conto, "Dafne adormecida", que se demora um pouco mais na composição de seu protagonista - ou à descrição de cenários nesse caso uma exceção que pode ser apontada é "Os mortos de Marquês de Sade", no qual há certa dedicação à construção da cidade onde se passa a trama. Essas exceções, entretanto, trazem apenas indícios do estilo descritivo do autor, sem se constituir como exemplos que possam ser comparados aos trabalhos posteriores de Galera, que serão analisados ainda neste capítulo.

Essas características são percebidas pelo próprio Daniel Galera, que, ao comentar seu primeiro livro, observa que:

[o]s contos reunidos em Dentes guardados foram escritos quando eu tinha 18, 21 anos, quando era não só uma pessoa em formação, mas um leitor em formação também. Ainda estava procurando minha voz e estudando outros autores. Depois 
percebi que a literatura concreta, mais descritiva me impressionava muito. (...) Então, descrever, para mim, não é aleatório, é o que me move como leitor. ${ }^{8}$

Até mesmo por ser um livro de contos, as narrativas desta primeira publicação não investem no detalhamento desses elementos, estando mais voltadas, em sua maioria, para uma tentativa de desvelamento de sentidos a partir de pequenos eventos triviais. Se existem alguns poucos episódios descritivos mais marcantes, eles estão voltados especificamente para os acontecimentos em si, e não para o que poderia haver em torno deles. E uma constante neste primeiro livro de Galera me parece estar justamente a serviço do próprio gênero, ligada à clássica comparação de Cortázar entre o romance e o conto, segundo a qual:

(...) o romance e o conto se deixam comparar analogicamente com o cinema e a fotografia, à medida em que uma película é, em princípio, uma "ordem aberta", romanesca, enquanto uma fotografia bem-sucedida pressupõe uma apertada limitação prévia, imposta em parte pelo reduzido campo abarcado pela câmera e pela forma em que o fotógrafo utiliza esteticamente essa limitação. (Cortázar, 2008, p.151-152)

De fato, as narrativas de Galera neste primeiro livro são fragmentos, espécies de recortes de determinados momentos conturbados da vivência de seus protagonistas, situações nas quais eles são desestabilizados por acontecimentos e imprevistos externos, mas, principalmente, por insatisfações e dilemas interiores causados por esses mesmos acontecimentos e imprevistos - que vão desde uma briga de namorados por causa de uma escova de dente, como em "Intimidade", a um encontro involuntário com uma garota de programa, o que ocorre em "Alguma psicologia", e um anúncio de gravidez, como em "Clichê romântico" - momentos esses que podem ser comparados àquilo que, no mesmo texto, Cortázar chama de "tremor de água dentro de um cristal".

\footnotetext{
${ }^{8}$ Entrevista do autor no projeto Segundas Intenções, promovido pela Biblioteca de São Paulo, em 2013. Disponível em: 〈https://www.youtube.com/watch?v=Fj5OENcsonY\&t=1244s > e <https://www.youtube.com/watch?v=Z1XO4a0Ya1A>.
} 
Outra questão que pode ser destacada neste livro de estreia de Galera são as referências a lugares reais e a elementos da cultura pop contemporânea, característica que irá se intensificar em suas produções posteriores. No caso de Dentes guardados, Galera usa algumas dessas referências para situar seus personagens tanto em uma perspectiva espacial como geracional.

O conto "Dafne adormecida", por exemplo, traz referências espaciais que situam seus personagens na cidade de Porto Alegre, como a passagem na qual o narrador faz menção a um parque e a uma rua da mesma cidade:

Lá pelas quatro me ligam da redação. Um incêndio no Parque Marinha. Pedem pra eu ir cobrir. Pego um táxi, peço nota fiscal, e quando desço na Borges de Medeiros há um carro de bombeiro no local, o fogo está quase apagado. (Galera, 2004, p. 75)

Já em "Alguma psicologia", o narrador inicia o conto esclarecendo que a personagem - que ele depois descobrirá ser uma garota de programa - “[e]ra uma garçonete de um café no Nova Olaria" (Galera, 2001, p. 60), centro comercial localizado no bairro Cidade Baixa, também em Porto Alegre, mesma cidade onde, no conto "Será numa quinta-feira", o narrador descreve o percurso da protagonista:

Percorrerá pela primeira vez toda a beira urbana do Rio Guaíba, encantando-se com a abundância de árvores e a quietude da Assunção. Atravessará a Tristeza atenta às pessoas que transitam nas calçadas. (Galera, 2004, p. 29)

A presença dessas referências no livro, entretanto, se dá de forma pouco recorrente, atuando apenas como pequenos indícios dos cenários nos quais os personagens transitam, nada que possa ser comparado ao detalhamento da recriação dos bairros, ruas e outros locais de Porto Alegre elaborada nos outros romances nos quais a cidade também é cenário das tramas, Mãos de cavalo e Meia noite e vinte.

Com relação às referências geracionais e culturais, é possível elencar alguns elementos que ajudam a situar e caracterizar os personagens como jovens em 
contato com a cultura alternativa do final dos anos 90 e início dos anos 2000 . No já citado "Dafne adormecida", por exemplo, há mais de uma alusão ao Garagem Hermética - casa de shows de Porto Alegre conhecida por, nos anos 90, promover apresentações de bandas da cena independente da cidade e, inclusive, ter sediado as festas e lançamentos do Cardosonline - como um local frequentado pelos personagens.

Já em "Intimidade", quando o narrador se refere à música que a namorada está ouvindo, diz que "podia escutar por trás desse fascinante monólogo o som dos fones de ouvido, era uma fita da PJ Harvey" (p.13) - cantora e compositora britânica, apontada como um dos principais nomes do rock alternativo da década de 90 -, enquanto o protagonista de "Manual para atropelar cachorros" reclama: "Há duas semanas não faço nada no trabalho. No início eu gostava, podia ficar navegando na internet e baixando músicas no Napster, mas agora o setor de tecnologia instalou um firewall e fudeu tudo" (p. 53) - se referindo ao programa de compartilhamento de arquivos que revolucionou a internet no início dos anos 2000 .

Entretanto, assim como no caso das referências espaciais, a presença desses elementos em Dentes guardados é bastante reduzida, atuando apenas como pistas que situam os personagens dentro de um recorte de uma determinada geração, sem, no entanto, se acumularem ou se desenvolverem no sentido de recriar ficcionalmente um universo, como ocorre nos livros posteriores de Galera.

O livro seguinte do escritor, Até o dia em que o cão morreu, se aproxima do seu livro de estreia principalmente no que se relaciona à questão temática. É possível observar, mais especificamente, uma proximidade entre o último conto de Dentes guardados, o já citado "Dafne adormecida", e esse romance posterior, ambos focados em dilemas de jovens às voltas com questões relacionadas ao início da vida adulta.

Narrado em primeira pessoa, o romance gira em torno de episódios da vida de um jovem de cerca de 25 anos que, após cumprir as etapas que considerou necessárias em sua vida até ali, se vê em um apartamento vazio, sem emprego, planos ou perspectivas e, mais do que isso, sem nenhuma vontade de tê-los: 
Apenas segui o caminho natural das coisas, como me ensinaram que elas deviam acontecer. Onze anos de colégio, quatro de universidade. Fiz minha carteira de identidade, meu título de eleitor, meu CPF, abri minha própria conta no banco, fiz carteira de trabalho, registro no INSS. Aulas particulares de inglês, três anos praticando remo, carteira de motorista. Segui o roteiro à risca, desde que nasci. Com o diploma de Letras na mão, viajei dois meses pela Europa, gastando economias que tinha desde a adolescência. Na volta, aluguei um apartamento e saí de casa. O nome disso é inércia. Qual o próximo passo? Vamos lá. Conseguir um emprego e ganhar a vida era a continuidade natural desse processo todo. Demorou mais de um ano pra eu perceber que não seria assim. As janelas daquele apartamento eram amplas demais, a vista dos dezessete andares ia demasiado longe. Todos os anos anteriores pareceram uma brincadeira idiota, e não havia nenhuma ideia que me estimulasse pro futuro. (Galera, 2007, p. 33-34)

Todo o enredo do livro se passa em Porto Alegre e são frequentes as citações a lugares da cidade, como o Guaíba, a Usina do Gasômetro, a Cidade Baixa e várias ruas pelas quais o protagonista transita. Essas referências marcam o romance de forma um pouco mais recorrente do que no primeiro livro de Galera, os cenários da cidade são descritos com um pouco mais de detalhes e o deslocamento dos personagens é marcado de forma mais específica.

As referências a elementos da cultura contemporânea, entretanto, aparecem de forma bem mais esparsa. Com exceção de uma menção ao programa de edições de imagens Photoshop e aos filmes Pulp Fiction e Sociedade dos poetas mortos, quase nenhuma alusão é feita a elementos que compõem o universo do protagonista, ao contrário do que pode ser observado em outras obras do autor.

Até o dia em que o cão morreu é mais centrado em pequenos episódios ligados à relação do protagonista com outras pessoas, como sua namorada, seus pais e o porteiro do prédio, e com o cachorro que passa a cuidar, e com os desdobramentos internos que o personagem experimenta a partir dessas relações. O desenvolvimento do romance se dá principalmente por meio da descrição desses encontros e de recortes avulsos da vida do narrador e de suas reflexões sobre esses acontecimentos, como quando um determinado olhar de Marcela, a namorada, motiva uma divagação do narrador sobre os relacionamentos amorosos: 
No entanto ela me encarava sorrindo, com os mesmos olhos que eu encontrava antes nas manhãs, um olhar que nos conectava e expressava que éramos parte um do outro. É difícil imaginar sensação de maior conforto e serenidade do que esta, que surge da ilusão elaborada de que fazemos parte da vida de uma pessoa a ponto de estarmos verdadeiramente unidos, de tudo estar bem se o outro estiver por perto, se apenas nos for dada a chance de saciar os desejos e interesses um do outro, de tolerar um ao outro quando sacrifícios forem necessários e deixar que todo o resto se foda, se destrua e morra, porque não haverá problema. Aquele olhar dela era uma manifestação perfeita dessa ilusão confortadora. Durava pouco, apenas instantes, como qualquer êxtase, mas era eficaz. (Galera, 2007, p. 81)

A criação desse universo íntimo do protagonista é o ponto que merece mais atenção na elaboração do romance, ocorrendo por meio de descrições dos sentimentos e estados de espírito do personagem. E uma questão primordial em Até o dia em que o cão morreu é justamente a subjetividade. Toda a ação se dá a partir do modo como o protagonista experiencia intimamente determinados episódios, que vão desde um passeio perigoso de moto - "Eu sentia o motor da moto tremendo entre as minhas pernas, e o vento frio entrava pelo visor aberto do meu capacete com tanta força que me arrancava lágrimas" - a uma lembrança de sua infância, quando presenciava o avô abater uma ovelha:

\begin{abstract}
Antes do abate, eu gostava de afagar a ovelha, olhar nos seus olhos, atento à sua respiração. Tinha a impressão de que ficavam resignadas com seu destino, embora estivessem apenas paralisadas pelo medo. E quando estavam com o pescoço aberto, eu acompanhava a vida escapando-lhes lentamente do corpo, obcecado em identificar o ponto exato em que já não estavam vivas, não estavam mais ali. Aí a tensão desaparecia. Eu tocava o corpo. Já não era uma ovelha. (Galera, 2007, p. 36)
\end{abstract}

E é justamente essa subjetividade que aponta para características que poderão ser observadas na produção subsequente de Daniel. Entretanto, ao contrário de outros livros do autor, não são muitas as passagens nas quais isso ocorre de forma mais detalhada - nesse sentido, a divagação motivada pelo olhar de Marcela é quase uma exceção -, mesmo as reflexões mais profundas e os sentimentos mais contraditórios são narrados de forma concisa, como na passagem a seguir: 
Os pedestres se protegiam como era possível, guerreando com guarda-chuvas, se amontoando debaixo de marquises e paradas de ônibus, alguns poucos enfrentando a chuva com a resignação de quem sabe que vai se molhar de qualquer jeito. Centenas de estranhos que não significavam nada pra mim, mas observá-los pela janela embaçada me dava uma comoção esquisita. (Galera, 2007, p. 51)

Essa "comoção esquisita" à qual o personagem se refere não é detalhada ou desenvolvida, mas é um estado emocional sinalizado, um momento íntimo do personagem surgido diante de uma situação prosaica que não tem, aparentemente, nenhuma relevância na narrativa, sendo apenas uma circunstância mínima na qual é revelada uma breve reflexão particular.

Porém, ao mergulhar na subjetividade de um narrador, abordando seus dilemas mais íntimos, e investindo, mesmo que de forma contida, na caracterização de cenários, Galera realiza em Até o dia em que o cão morreu uma espécie de ensaio de estilo que aponta para alguns dos rumos que sua obra seguirá a partir desse livro, como será possível observar ao longo das próximas seções deste capítulo.

\section{2. \\ Mãos de cavalo: descrever, sentir, enxergar}

Lançado em 2006, Mãos de cavalo foi o primeiro livro de Galera publicado por uma grande editora, a Companhia das Letras. O romance conta a história de um personagem, Hermano, em fases distintas de sua vida, por meio de episódios aparentemente desconectados entre si, que trazem à tona aspectos distintos relacionados à construção da identidade do protagonista.

Um aspecto que se destaca neste livro diz respeito à estrutura do romance e ao modo como Galera alterna, ao longo de toda a obra, dois planos narrativos: um relatando alguns episódios isolados da infância de Hermano, distribuídos ao longo dos oito capítulos ímpares, com títulos como "O ciclista urbano", "O morro", "Downhill" e "A festa de quinze da Isabela" e outro plano que, nos sete capítulos pares, narra um período de menos de duas horas na vida de Hermano já adulto, 
com títulos referentes ao horário no qual a ação do capítulo está se passando: o primeiro é "6h08" e o último " $8 \mathrm{~h} 04$ ".

Neste livro, o texto de Galera continua, como nos anteriores, sendo marcado por referências espaciais, mas isso ocorre de forma mais acentuada. Todo o livro é permeado por descrições minuciosas de lugares de Porto Alegre; ruas e bairros são nomeados, percursos inteiros são pormenorizados, locais públicos são detalhados, como nas passagens a seguir:

A tarde caía na Esplanada. (...) Do outro lado das águas do Guaíba, o sol vermelho ameaçava tocar a difusa linha dos morros. (...) Às costas de Hermano estava o Morro da Polícia, com seus cerca de duzentos e cinquenta metros de altura, propriedade do Exército Brasileiro. (...) Para chegar ao Morro, antes era preciso atravessar o Mato, um bosque abundante em cipós, córregos, lagartos, cobras (...). À direita de Hermano, em aclive formado por uma sequência de longos e suaves degraus no terreno, se estendia o restante da praça, com parquinho infantil, quadra de bocha, uma churrasqueira coberta e alguns bancos de cimento. Na percepção de Hermano, não havia harmonia entre todos esses elementos. Não pareciam fazer parte de um mesmo ambiente, no caso a praça principal da Esplanada, que era o nome de um loteamento residencial, mas operava na psicologia de seus moradores como algo muito mais imponente, como o nome de um verdadeiro bairro. Se a Esplanada ainda não era um bairro, um dia seria. (Galera, 2007, p. 32)

O nome suscita uma nostalgia difusa, não de todo agradável, pra dentro da qual tem a sensação de penetrar fisicamente ao deixar o último trecho reformado da Aparício Borges e prosseguir caminho naturalmente pela Avenida Teresópolis, que segue em obras por algumas centenas de metros até dar lugar a um cenário que lhe parece preservado, com o mesmo asfalto antiquado e os canteiros centrais com árvores enormes que lembrava ver com frequência até uns cinco anos atrás, quando ainda morava na zona sul e costumava passar por ali. Fantasia que a construção interminável da Terceira Perimetral é uma ameaça que o persegue e contra a qual agora, dentro do carro, está apostando uma corrida, como já tinha apostado corrida contra a sombra de nuvens em estradas. (...) era necessário afundar o pedal do acelerador e chegar à Esplanada antes que fosse tarde. (...) E assim, rapidamente, a avenida Teresópolis se transforma na avenida Nonoai que se transforma na avenida Eduardo Prado, um trajeto ainda adormecido em que o progresso urbano dos últimos cinco anos deixou marcas variadas porém relativamente superficiais. (...) é pro cenário de sua juventude que está indo agora, pegando à esquerda na nova rotatória da Eduardo Prado com a Juca Batista. (Galera, 2007, p. 105-106)

A primeira passagem acontece no arco da infância de Hermano. A segunda é o momento no qual o Hermano adulto se vê inexplicavelmente dirigindo em direção ao Esplanada, bairro onde cresceu - e é justamente esse deslocamento espacial que marca o encontro dos dois arcos narrativos. Hermano, já adulto, mora em outro bairro e deveria estar se dirigindo para a casa de um amigo em outro 
lugar, mas, tomado por dolorosas lembranças de sua infância que vieram à tona diante de questões que está enfrentando em sua vida adulta, acaba se sentindo impelido a retornar ao "cenário de sua juventude".

As referências a elementos da cultura pop também são constantes, funcionando no sentido de contribuir com a construção e delineamento dos personagens, situando-os dentro de um determinado recorte geracional. O primeiro arco narrativo, da infância de Hermano, se passa no início dos anos 90, conforme especificado pelo narrador no início do capítulo “Downhill”. Entretanto, mesmo se não houvesse essa especificação, seria possível situar a vivência de Hermano nesse período por meio das várias referências encontradas ao longo do romance.

São constantes as alusões a elementos culturais da década de 90, como músicas, filmes, brinquedos e videogames. Em uma festa, por exemplo, "as canções da trilha sonora internacional da novela Vamp se sucediam nas caixas de som”, além de artistas de Lenny Kravtiz e Guns 'N Roses, cujas músicas fizeram sucesso nessa época. Os personagens citam filmes como Mad Max 2: a caçada continua e Uma Noite Alucinante: A Morte do Demônio (ambos de 1981) e o protagonista guarda em seu quarto "meia dúzia de bonecos Comandos em Ação", que foram comercializados no Brasil entre 1984 e 1995. Hermano possui "um combo de televisão colorida catorze polegadas e um videogame Phantom System”, console lançado em 1988, e seus amigos são entusiastas de jogos de videogame que marcaram a década de 90, como Golden Axe e Space Quest, entre vários outros citados ao longo do livro.

Essa questão da tecnologia, inclusive, também tem papel importante nessa construção do cenário geracional do livro. Enquanto Hermano, com 30 anos, enumera itens tecnológicos que possui, como "câmera fotográfica digital 7.2 megapixels, iPod, GPS" e recebe por email "um par de coordenadas e um link pra fazer o download de um programa chamado Google Earth", quando criança o personagem é apresentado em detalhes a um computador - descrito pelo amigo como "um 386 DX. Com trinta e três megahertz e memória RAM de quatro megas (...) O disco rígido tem oitenta megas" - que, quando se passa a ação do segundo plano narrativo (localizado em 2005 ou 2006, devido à idade do 
protagonista) já é completamente ultrapassado, mas no início da década de 90 era o auge da tecnologia possível na época, "um modelo poderoso", como sublinhado pelo narrador.

Entretanto, no início deste capítulo falei da complexidade narrativa do romance em relação aos primeiros livros de Galera; ela vai além da simples intensificação no uso das estratégias utilizadas em Dentes guardados e Até o dia em que o cão morreu, pois em Mãos de cavalo o empenho descritivo do autor transcende esses artifícios, inaugurando novas possibilidades em sua obra.

Acredito que essa complexidade se realize de duas formas distintas, mas ambas ligadas à construção realista do romance e relacionadas ao modo como o autor lida com os aspectos sensoriais ao longo do livro e a relação desses aspectos com a tentativa de construção de visualidades. E é interessante observar, ainda, que essas estratégias estão intrinsecamente vinculadas ao enredo do livro, ou seja, existe uma dinâmica no nível formal que se articula no sentido de buscar um efeito associado aos temas do romance.

Para compreender como esse movimento ocorre, é necessário discorrer sobre alguns aspectos do enredo do livro. O protagonista Hermano tem uma relação ambígua com a dor e o sangue, contornada de medo e fascínio - o medo que faz com que ele se esconda enquanto um amigo é espancado até a morte e o fascínio que o impulsiona a descer uma escadaria de bicicleta a toda velocidade provocando, voluntariamente, uma queda monumental, trechos que serão analisados a seguir - e, como resultado dessa relação, há uma forte presença do questionamento e da autoanálise de seus limites físicos. Essa tensão se apresenta no livro por meio de representações sensoriais e imagéticas, como já no início do primeiro capítulo, onde, depois de um tombo de bicicleta, o protagonista encontra prazer em suas dores, feridas e, principalmente, na contemplação do próprio sangue:

O joelho continua a sangrar durante toda a subida da rua do Canteiro (...). Um fio vermelho desce do lábio inferior pelo queixo e de tempos em tempos pinga entre suas pernas. É como se houvesse câmeras escondidas atrás dos postes registrando sua tenacidade física, sua recuperação vigorosa após uma queda espetacular. Cada gota vermelha é aguardada com expectativa. (Galera, 2006, p. 20) 
O tema perpassa todo o livro, mas volta à tona com maior intensidade no capítulo "A clareira", que narra o confronto que resulta na morte de Bonobo, amigo de Hermano, que é agredido enquanto o protagonista se esconde em um local próximo. Após a fuga dos agressores, Hermano constata que Bonobo está desacordado e provavelmente morto, mas não tem coragem de contar ao resto dos amigos que se comportou de maneira covarde e inventa outra versão da história, na qual se envolveu na briga tentando, sem sucesso, defender o amigo. Para que a versão seja crível, Hermano se autoagride, para que assim tenha marcas visíveis do confronto do qual ele, em verdade, não participou:

(...) a solução encontrada no momento veio na forma de um soco, não uma figura de expressão e sim um soco literal que Hermano deu nele mesmo, no próprio rosto, e depois se jogou no chão para se sujar e puxou a camiseta até abrir um rasgo e deu mais outro soco e outro e outro e finalmente descobriu qual era a sensação de apanhar e bater numa briga pra valer, eram sucessivas dores pontiagudas e latejantes que traziam à mente o formato dos $\operatorname{ossos}^{9} \mathrm{e}$ a distribuição dos nervos $\mathrm{e}$ iam se acumulando até formarem uma dor só, menos pontiaguda, mais amortecida, mais fácil de suportar a cada golpe, o gosto do sangue meio doce e meio azedo, como um molho ácido de tomate, brotando com facilidade do lábio rachado, do nariz, do supercílio aberto, e vencidos os primeiros momentos de dor a coisa até que ficou fácil, tinha sido um alívio sentir aquilo de verdade, pela primeira vez na própria carne e não nos devaneios fantasiosos ou nos filmes e quadrinhos, pela primeira vez deixar rolar e descobrir que sentir era fácil, difícil era imaginar. (Galera, 2006, p. 91-92)

Além da sequência do tombo de bicicleta que abre o livro, citada anteriormente, existe outra queda cuja narração é especialmente interessante para essa análise. Isso porque, enquanto o primeiro tombo é um acontecimento normal e imprevisto, o segundo é provocado por um risco deliberadamente assumido pelo personagem Hermano em uma disputa de downhill. Essa segunda sequência é particularmente significativa dentro do romance, não só por explicitar a insólita atração que o personagem sente pela dor e pelo próprio sangue, mas também por ser exemplar do modo como Galera trabalha as descrições sensitivas:

Ninguém jamais desceria aquela escadaria mais rápido do que ele estava descendo agora. Era impossível. Tinha impressão de que as rodas nem tocavam o chão. (...) Nos primeiros segundos de descida, percebeu que já não tinha controle da bicicleta.

\footnotetext{
${ }^{9}$ Mãos de cavalo foi recentemente traduzido para o inglês e publicado nos EUA justamente com o título de The Shape of Bones.
} 
Mesmo assim continuou pedalando mais e mais. Sabia que ia cair. E todos iam ver ele cair. Enquanto descia, teve consciência de que era apenas isso que o movia a descer aquela escadaria tantas vezes, a possibilidade da queda, de se arrebentar no chão. (...) Estava pronto para sangrar. Era seu talento. (...) agora ele seria capaz de cortar, quebrar, ralar, escoriar, debulhar, raspar, fraturar, arranhar, perfurar e esmagar seu próprio corpo de um jeito que ninguém jamais esqueceria. (...) Quando seu próprio corpo parou de capotar, Hermano levou as mãos ao rosto, depois as afastou e ali estava ele, na ampla palma de suas mãos, nos dedos fortes e grossos. Havia gente correndo escadaria abaixo em sua direção (...) Os espectadores correndo para socorrer o herói do filme. O seu filme. A cena ficou perfeita. A maquiagem não podia ter sido mais realista. Como o sangue é uma coisa bonita, pensou antes de desmaiar. (Galera, 2006, p. 92)

A forte presença da representação dos limites físicos é aqui acrescida, assim como no primeiro tombo - "É como se houvesse câmeras escondidas atrás dos postes registrando sua tenacidade física" - de uma correspondência com a representação possibilitada pelo cinema e essa estratégia pode ser diretamente a outra questão que pode ser destacada na leitura de Mãos de Cavalo: a apropriação da linguagem cinematográfica, evidenciada não só por meio de técnicas, mas também de referências diretas, como ocorre desde a epígrafe - "Eu caminhava para a escola e ia imaginando planos em que uma grua subia aos poucos e me via lá embaixo como um pequeno objeto no meio da rua, caminhando para a escola." -, uma frase do ator Nicolas Cage, até a recorrente referência à relação entre as experiências de Hermano e uma suposta câmera, presente em vários momentos do livro, como na passagem reproduzida a seguir:

Às vezes a câmera surgia nos instantes cruciais de sua existência, às vezes captava a realidade de momentos banais e solitários, quando estava correndo em Ipanema e começava a chover, quando descia do ônibus e entrava pelo portão da frente do colégio, quando andava de bicicleta em alta velocidade, por horas a fio, atravessando diversos bairros da cidade, ou quando subia o Morro da Polícia como se estivesse sozinho, praticamente ignorando a companhia dos amigos, pois havia apenas ele, o morro e a câmera. Não era simplesmente sentir-se observado, imaginar testemunhas indefinidas pra cenas de sua vida. Era como se ele mesmo se destacasse do corpo para se tornar o observador da cena, atravessava a membrana entre a realidade e a imaginação e escolhia uma cadeira na plateia vazia de um cinema escuro. (Galera, 2006, p. 139-141)

Além das passagens destacadas, o próprio léxico e as metáforas utilizadas pelo autor em vários momentos são diretamente retirados da linguagem cinematográfica, como quando o clima de uma festa é descrito como a "aura 
cenográfica da situação" e Hermano e seus amigos como "atores inseguros representando seus papéis" (p.115), ou quando o protagonista imagina um confronto físico e "[s]ua imaginação trabalhava como se projetasse um filme, cortando a luta encarniçada em planos, coreografando cada golpe e abusando da câmera lenta" (p. 84).

Todas essas estratégias contribuem com a criação de uma relação muito próxima entre texto e imagem, agenciada de formas distintas, mas sempre almejando a concretização de uma visualidade que busca se realizar por meio do próprio texto. Essa questão da visualidade remete a um aspecto da literatura contemporânea apontado por Vera Follain de Figueiredo, que afirma:

Buscando fazer uma literatura para ser lida como um filme, mais até do que para ser filmada, autores utilizam tópicos da cultura audiovisual como mediação entre o texto e o leitor. Seguindo esta direção, a ficção literária contemporânea, cada vez mais, assimila o ritmo dos cortes rápidos e procedimentos de montagem de cenas próprios da linguagem cinematográfica. (Figueiredo, 2012, p. 143)

Vera destaca a questão da montagem e do corte e esses talvez não sejam exatamente os recursos mais utilizados por Daniel Galera em Mãos de cavalo, por exemplo, que trabalha mais, como falado anteriormente, com construção de visualidades, linguagem cinematográfica e paralelismo entre as duas expressões artísticas. Entretanto, é interessante notar essa questão da "mediação entre o texto e o leitor", que, no caso de Galera no livro em questão, é realizada por meio de estratégias que buscam possibilidades de aproximação por meio de efeitos sensitivos e da construção de visualidades, que aproximam o leitor não só da trama e dos personagens, mas do que há de mais íntimo no universo do protagonista.

Existe uma contraposição significativa nesse movimento: enquanto o personagem vê a si mesmo à distância, atravessando a "membrana entre a realidade e a imaginação" e se colocando como espectador da própria vida, o narrador procura o efeito inverso, colocando, por meio das descrições, os leitores em contato com o universo interior de Hermano, não só em uma perspectiva psicológica, mas também física. E, por mais que o protagonista entenda, como diz 
a certa altura do romance, que "o sofrimento físico é solitário", todas as nuances dessas sensações são apresentadas aos leitores por meio das detalhadas descrições, como nos trechos apresentados anteriormente.

A partir do que foi discutido, é possível observar que o autor não só persiste na elaboração de suas tramas a partir de uma chave essencialmente realista, mas transcende artifícios anteriormente utilizados. Se nos livros anteriores era possível identificar as referências espaciais e culturais que atuavam como indícios e elementos que ajudam a construir um universo ficcional crível, o que vemos em Mãos de cavalo é um passo que vai um pouco além, com descrições que operam no sentido de tentar concretizar uma espécie de realidade física por meio das descrições sensoriais e da articulação dessas descrições no sentido de alcançar uma representação mais concreta, características essas que também estão presentes, de modos distintos, em Barba ensopada de sangue, como procurarei mostrar na próxima seção deste trabalho.

\section{3. \\ Barba ensopada de sangue: o nadador leva nos ombros o narrador}

Lançado em 2012, Barba ensopada de sangue conta a história de um professor de educação física que, após o suicídio do pai, decide morar em Garopaba, uma pequena cidade do litoral de Santa Catarina. Além de começar uma nova vida em uma cidade onde não conhece ninguém, o protagonista do livro - cujo nome não é revelado ao longo do romance, mas ao qual alguns personagens se referem ocasionalmente como "Nadador", devido ao costume do personagem de nadar longos percursos no mar e ao emprego de professor de natação que acaba conseguindo na cidade - tem uma motivação relacionada a descobrir mais detalhes sobre a morte do avô, que teria sido assassinado na cidade muitos anos antes.

Neste livro, algumas das características presentes nas obras anteriores de Galera são intensificadas, como as referências a elementos da cultura pop, por 
exemplo, as muitas as passagens que fazem alusões a canções de artistas contemporâneos como Coldplay, Little Joy, Ben Harper e John Frusciante ${ }^{10}$.

Há ainda referências a outros elementos culturais atuais, como a certa altura do romance em que o protagonista vai a uma lanhouse da cidade e acessa sua conta no Facebook, assiste a vídeos no YouTube e presencia uma turbulenta conversa por Skype. Em outro trecho, uma personagem comenta com ele assuntos como a vitória de Barack Obama, o lançamento do primeiro modelo de iPhone e a FLIP.

Ocorre, ainda, uma espécie de extremização da preocupação com as descrições e construções de cenários. A cidade de Garopaba é recriada no romance em seus mínimos detalhes nos aspectos geográficos, como a localização de determinadas ruas, praias e outros locais, que vão se descortinando para o leitor à medida que o personagem vai conhecendo e reconhecendo a cidade e seus pormenores. A construção do mundo exterior é fundamental no romance, como apontado na resenha de Karl Erik Schøllhammer, que ressalta "a precisão descritiva dos cenários escolhidos" e a empatia que esses mesmos cenários guardam "com os humores do personagem” (2013).

Por meio da descrição detalhada de aspectos físicos e naturais, Galera consegue imprimir na narrativa não só a ambientação física dos personagens na cidade de Garopaba, mas também vários aspectos inerentes àquela vivência que se materializa de maneira extremamente verossímil ao longo das páginas do romance. Sobre essa questão, o autor afirmou que:

Desde o começo, quis dar ao leitor essa sensação física da passagem do tempo. Para isso, tinha de mostrar a vida do protagonista mesmo nos seus aspectos mais banais. Na verdade, toda a sensação de tempo na ficção é ilusória. É uma construção do autor. Tanto podemos resumir uma saga familiar de cinco séculos em cinco linhas como esticar dez segundos da vida de uma pessoa em mil páginas. Quis que o leitor ficasse o mais próximo possível da sensação concreta do que é

\footnotetext{
${ }^{10}$ A referência ao músico norte-americano John Frusciante não é feita de forma direta no livro, mas por meio de outro mecanismo. Há uma nota de rodapé reproduzindo uma mensagem que o protagonista recebe de uma namorada dizendo "olha o clipe da música que a gente ouviu ontem e tu gostou, do carinha do red hot: http://www.youtube.com/watch?v=gZsbODz0V3Y”". O vídeo foi retirado do ar devido a problemas de direitos autorais, mas na época da escrita do livro direcionava para o clipe da música "The Past Recedes", de John Frusciante, conforme dito por Galera a um leitor em seu perfil no Twitter.
} 
viver em Garopaba. Que o leitor sentisse aqueles nove meses, não só os momentos em que acontecem coisas, em que a ação progride, mas também os espaços vazios, os hiatos, os períodos em que nada se passa. (Galera, 2014)

Apesar de ter alcançado consagração crítica (o livro foi vencedor do Prêmio São Paulo de Literatura 2013 e recebeu o terceiro lugar no Prêmio Jabuti de Romance), o estilo exageradamente descritivo de Barba ensopada de sangue dividiu a opinião de leitores e resenhistas. É fácil encontrar na internet e na imprensa em geral tanto comentários que destacam negativamente as longas descrições ("prolixidade tergiversiva que beira o desespero"; "Galera sucumbe, enfim, a uma caricatura do romance de fôlego"), como opiniões elogiosas que consideram essa característica como um dos pontos mais positivos do livro ("o enredo, bem tramado, utiliza as descrições pormenorizadas para adensar seu conteúdo, sem resvalar na repetição"; "No final temos a impressão que não lemos o livro, mas vimos o filme. Dos bons, e em 3D"11).

O próprio autor confirma que, de fato, buscou em seu romance um registro o mais próximo possível do realismo descritivo, uma vez que, como leitor, tem preferência por esse estilo e considera que a literatura mais interessante é aquela que consegue fazer com que a descrição do mundo supere a descrição da psicologia dos personagens e o fluxo de consciência ${ }^{12}$.

Nesse contexto, o distúrbio neurológico que o protagonista do livro possui propagnosia, a inabilidade de reconhecer rostos - é particularmente significativo para o movimento narrativo e para o estilo construído pelo autor, uma vez que temos, portanto, uma relação entre a narração em si e o modo peculiar por meio do qual o personagem se conecta com o mundo.

De acordo com Galera - que pesquisou a doença frequentando fóruns de portadores de propagnosia -, quem possui esse distúrbio aprende desde cedo a prestar atenção em outros detalhes, como roupa, gestos, mãos, cabelos e, a partir

\footnotetext{
${ }^{11}$ A segunda observação foi retirada da crítica de Alfredo Monte para a Folha de S. Paulo e as demais são comentários de leitores postados em blogs e na plataforma de leitura Skoob.

${ }^{12}$ Entrevista do autor no projeto Segundas Intenções, promovido pela Biblioteca de São Paulo, em 2013. Disponível em: 〈https://www.youtube.com/watch?v=Fj5OENcsonY\&t=1244s > e <https://www.youtube.com/watch?v=Z1XO4a0Ya1A>.
} 
desses e de outros detalhes, tenta identificar as pessoas a seu redor, uma vez que não pode contar com a habilidade sequer de reconhecer o próprio rosto. $\mathrm{O}$ autor procurou então imprimir no próprio estilo da escrita essa condição neurológica, e isso pode ser percebido em vários momentos nos quais a narrativa avança juntamente com as tentativas de reconhecimento de outros personagens empreendidas pelo protagonista, como é possível perceber já nas primeiras linhas do primeiro capítulo do livro:

Vê um nariz batatudo, reluzente e esburacado como uma casca de bergamota. Boca estranhamente juvenil entre queixo e bochecha tomados por rugas finas, pele um pouco flácida, barba feita. Orelhas grandes com lóbulos maiores ainda, parecendo esticados pelo próprio peso. Três sulcos profundos na testa, horizontais, perfeitamente paralelos e equidistantes. Dentes amarelados. Cabelos loiros abundantes quebrando numa única onda por cima da cabeça e escorrendo até a base da nuca. Seus olhos percorrem todos os quadrantes desse rosto no intervalo de uma respiração e ele pode jurar que nunca viu essa pessoa na vida, mas sabe que é seu pai (...). (Galera, 2012, p. 13)

O mesmíssimo movimento ocorre no início do último capítulo, quando o protagonista recebe a visita da ex-namorada Viviane:

Vê dois olhos verde-cinzentos entre maçãs do rosto carnudas que puxam covinhas em torno de um sorriso perolado e expectante. (...) Seus olhos percorrem todos os quadrantes desse rosto no intervalo de uma respiração e ele pode jurar que nunca viu essa pessoa na vida, mas de repente sabe quem ela é. (Galera, 2012, p. 404)

Apesar de ter o foco em terceira pessoa, a narração é intimamente colada ao protagonista - na definição do próprio Galera, uma "mistura de narrador onisciente com narrador em primeira pessoa, como se o narrador onisciente optasse por ficar sempre acomodado nos ombros do personagem" - e esse tipo de descrição gradual se coloca como um recurso de estilo que, ao mesmo tempo em que reforça uma característica do personagem, coloca os leitores em contato com determinados aspectos relacionados tanto a questões psicológicas - uma vez que sabemos todos os pensamentos e sentimentos do protagonista - como físicas assim como ocorre no romance Mãos de cavalo. 
E foi justamente essa proximidade do narrador e do protagonista que fez com que Galera usasse no romance o já citado recurso das notas de rodapé, conforme explicado pelo autor:

Usei as notas de rodapé no Barba ensopada de sangue com um objetivo específico: incluir algumas cenas e diálogos que aconteciam fora do alcance dos sentidos ou do conhecimento do protagonista. Escolhi me ater, na narrativa principal, somente ao ponto de vista dele (...) Assim, eu não tinha como fornecer, por exemplo, a conversa entre a mãe e o irmão dele no velório do pai, uma vez que ele não a testemunha nem nunca fica sabendo que a conversa ocorreu. Depois até aproveitei o recurso pra incluir algumas dicas cifradas e pistas que poderiam ajudar a montar certas peças do enredo e psicologia do protagonista. (Galera, 2016)

Outro elemento que é construído por meio de descrições pormenorizadas são algumas cenas que não parecem ter uma função concreta dentro da lenta ação do romance, mas que auxiliam na composição imagética de determinadas situações e lugares, como na passagem a seguir:

Quando está se aproximando do catamarã escuta gritos de alerta. Esbaforido e com os óculos embaçados, estica a cabeça para fora d'água e vê dois tripulantes na popa gritando e agitando os braços. Tira os óculos e olha ao redor tentando ver ou ouvir alguma embarcação vindo em sua direção ou talvez um boto ou sabe lá o quê. Um dos homens no catamarã gesticula para que ele se aproxime e aponta para alguma coisa na traseira do barco. Ele nada com cautela e ao chegar um pouco mais perto enxerga por cima das ondas um animal reluzente na plataforma de popa. É uma foca corpulenta, cor de grafite, com algumas manchinhas claras e escuras. Os homens estão rindo encantados com o mamífero desengonçado e bigodudo que troca de apoio sem parar nas nadadeiras. Chega a poucos metros do barco. Um dos homens diz que a foca estava ali quando eles acordaram e não dá sinais de querer ir embora. Eles acham que ela está com fome e o outro homem entra na cabine por um instante e retorna com um peixe pequeno. A foca dá uma olhada no peixe que o homem chacoalha sobre a sua cabeça, solta dois berros altos, fanhos e curtos que parecem ser de puro escárnio e após uma pausa dramática salta no mar com destreza e mergulha sem espirrar uma gota. Os três homens se olham sem saber o que dizer (...). A foca sai da água e crava a mesma posição de antes na plataforma de popa, dando um salto digno de uma ginasta. Trouxe um peixe grande na boca, pelo menos três vezes maior que o oferecido pelos anfitriões. O peixe se debate até que ela cansa de se exibir e o devora. (Galera, 2012, p. 168)

Em nenhum outro momento do livro o episódio é citado novamente e, a partir dele, nenhuma ação é criada ou desencadeada. Sequer o desfecho da 
situação é apresentado ao leitor e, à primeira vista, a passagem, portanto, não parece ter sua existência justificada.

A sequência na qual o protagonista avista uma fata morgana, miragem causada pela inversão térmica, também não constrói maiores sentidos nem para o enredo nem para os personagens, entretanto, constitui-se como um acontecimento que, assim como o da citação anterior, ajuda de alguma forma a moldar a ambientação da trama, focada em aspectos da natureza, da existência e das relações interpessoais, muito mais do que em grandes eventos ou reviravoltas imprevisíveis ou emocionantes.

Essa questão é, de certo modo, levantada por Roland Barthes no clássico ensaio "O efeito do real", no qual são analisadas narrativas nas quais detalhes classificados como irrelevantes são utilizados para criar uma atmosfera de realidade - como o exemplo do barômetro em "Um coração simples" (Gustave Flaubert) - resultando no que é chamado no texto de "ilusão referencial".

Ao analisar a teoria de Barthes, o crítico James Wood observa que esses detalhes e efeitos literários

Não são apenas convencionalmente irrelevantes ou formalmente arbitrários, mas têm algo a dizer sobre a irrelevância da própria realidade (...) a categoria do irrelevante ou inexplicável existe na vida, assim como o barômetro (...) A vida, então, sempre encerra um excedente inevitável, uma margem de gratuidade, um campo em que sempre há mais do que precisamos: mais coisas, mais impressões, mais lembranças, mais hábitos, mais palavras, mais felicidade, mais infelicidade. (Wood, 2012, p. 79)

O uso da palavra "gratuidade" por Wood me parece aqui particularmente interessante, uma vez que a mesma palavra foi usada por um resenhista para definir as extensas e detalhadas descrições presentes em Barba ensopada de sangue, livro que apresentaria, segundo ele, episódios de "gratuidade narrativa" Ao rechear as páginas de seu romance com longas descrições e sequências aparentemente dispensáveis, o que Galera opera, portanto, é uma recriação crível

13 Resenha de Vinícius Justo publicada no site Amálgama em 2012. Disponível em: <https://www.revistaamalgama.com.br/12/2012/barba-ensopada-de-sangue-daniel-galera/.> . 
dos aspectos mais banais, que podem, ao mesmo tempo, ser apontados também como os mais essenciais da vida.

Quando analisa a importância da fotografia na contemporaneidade, Susan Sontag observa o quanto a preferência pela imagem à literatura pode estar relacionada a um desejo de contato com o real, uma vez que "[a]s fotografias parecem mais autênticas do que extensas narrativas literárias porque são tidas por fragmentos da realidade". Sontag afirma ainda que "[e]nquanto que uma pintura ou descrição em prosa jamais podem ser outra coisa que não uma interpretação estritamente seletiva, pode-se tratar uma foto como uma transparência estritamente seletiva" (Sontag, 2004, p. 16).

A subjetividade (que pode ser entendida aí a partir da oposição interpretação versus transparência) se configuraria então como uma espécie de obstáculo à representação do real. Nesse sentido, é possível entender o quanto a representação imagética pode se constituir como uma espécie de reação que afirma a demanda de real.

Esse artifício é identificado por Sontag já na literatura de Balzac. Ela comenta que a "operação balzaquiana consistia em ampliar pequenos detalhes, como numa ampliação fotográfica" (Sontag, 2004, p. 176), recurso bastante similar ao usado por Daniel Galera.

Se a imagem é considerada na cultura contemporânea como mais autêntica e detentora de uma maior legitimidade do que o texto, buscar construir visualidades por meio da literatura - como Daniel Galera faz não só em Barba ensopada de sangue, mas também em Mãos de cavalo, conforme discutido na seção anterior deste trabalho - aparece, portanto, como uma estratégia que segue justamente a lógica de aproximar ficção e realidade, em busca de uma elaboração verossímil do mundo, espelhando a busca pela experiência autêntica e transformando, assim, a própria busca também em matéria representável. 


\section{4.}

\section{A tecnologia da intimidade em Meia noite e vinte}

O enredo do livro mais recente de Daniel Galera, Meia noite e vinte, se articula a partir de quatro protagonistas e três narradores, Aurora, Emiliano e Antero. O quarto protagonista, Andrei, também chamado de Duque, acabou de ser assassinado quando a trama começa e é justamente devido a sua morte que os caminhos dos outros três personagens irão voltar a se encontrar, anos depois de terem sido amigos de juventude, tendo fundado, juntamente com Andrei, no final dos anos 90, um fanzine digital chamado Orangotango.

Se por um lado a voz de Andrei nunca é ouvida, por outro ele é um personagem central do livro, o que o coloca na situação de protagonista-ausente, ou seja, ele é parte essencial da trama, mas nunca aparece diretamente nela. Temos acesso a várias informações sobre ele - suas ações, história, hábitos, personalidade -, mas sempre de forma indireta, por meio do discurso, pensamento e da memória de outros personagens. E, inevitavelmente, o que alcançamos é o modo com Aurora, Emiliano e Antero enxergavam Andrei, com todas as distorções que uma visão subjetiva pode carregar consigo.

É impossível, ainda, não traçar um paralelo com o fictício Orangotango e o real Cardosonline. A passagem em que Emiliano fala sobre o surgimento da publicação é muito similar à história do Cardosonline, inclusive os temas, a frequência de envio, o detalhe da criação em uma época de greve, a partir dos emails enviados por Antero (no caso do Cardosonline, quem iniciou esses envios foi André Czarnobai, também conhecido na época como Cardoso) e a subsequente sistematização sugerida por Duque (e quem deu essa ideia no caso do Cardosonline foi o próprio Daniel Galera) ${ }^{14}$ :

\footnotetext{
${ }^{14}$ Informações retiradas da matéria "Literatura na internet: a egotrip do Cardosonline, um século depois", publicada no site Sul21 e disponível no link: http://www.sul21.com.br/jornal/a-grandeegotrip-do-cardosonline-um-seculo-depois/.
} 
No site de Antero também havia um link pra home page do zine eletrônico enviado por e-mail que ele criara junto com Duque durante uma das greves da universidade federal, que os deixou sem absolutamente nada pra fazer. Tudo se iniciou, na verdade, com e-mails quilométricos que Antero começou a enviar pros seus colegas, recheados de contos pornográficos, poemas de verso livre cheios de links apontando pra bizarrices da internet, resenhas de filmes e discos e uma profusão de manifestos artísticos produzidos à base de maconha, LSD, ócio e leituras sui generis dos pós-estruturalistas. Os colegas passaram a responder aos e-mails com suas próprias contribuições, até que Duque teve a ideia de transformar as longas mensagens espontâneas numa publicação só de texto, distribuída duas vezes por semana por e-mail. O trio de colunistas fixos era completado por Aurora. Depois de colaborar com alguns textos meus, me aproximei deles e entrei pra equipe. No auge da nossa popularidade, tínhamos milhares de leitores, dezenas dos quais enviavam textos regularmente. (Galera, 2016, p. 44)

O fanzine digital, entretanto, é apenas uma de muitas referências à tecnologia no livro. Da cobertura dos protestos de junho de 2013 a conversas por WhatsApp, passando por palestras do TEDx e vídeos que viralizam na internet, muitos dos elementos que marcam a atualidade e seus desdobramentos estão presentes na obra.

É necessário apontar, entretanto, que, ao contrário do que ocorre nos livros anteriores, a tecnologia deixa de ser apenas um referencial, presente em indícios que ajudam a criar uma atmosfera contemporânea. Em Meia noite e vinte ela é quase um personagem, com papel importantíssimo nas vidas dos quatro protagonistas.

A repercussão da notícia da morte de Andrei na internet, por exemplo, é descrita de forma detalhada, com vários elementos que reproduzem o efeito que esse tipo de acontecimento de fato tem tido nos dias atuais, assim como o impacto que pode vir a ter nos indivíduos e o modo como eles reagem a isso, como é possível observar na passagem a seguir:

Olhei de novo, depois de um hiato torporizado, para a tela do celular, que ainda exibia uma matéria sobre o assassinato de Andrei Dukelsky no site da Zero Hora. Dei scroll na notícia, molhando toda a tela de vidro do iPhone com o suor do dedo. De acordo com a namorada do Andrei, uma tal de Francine Pedroso, ele tinha saído para correr em torno das nove e meia da noite e levava consigo somente a chave de casa e o smartphone, que foi roubado pelos criminosos. Não havia testemunhas, embora o local onde o crime aconteceu fosse uma área de movimento moderado, mesmo à noite. "Um dos maiores novos talentos da literatura brasileira contemporânea", era o aposto que o texto lhe concedia. "Duque, como era 
chamado pelos amigos". Havia uma hashtag \#AdeusDuque oferecendo consulta instantânea às manifestações de choque e tristeza de seus leitores e amigos nas redes sociais. Não tive coragem de clicar nela. (Galera, 2016, p. 11)

O mesmo ocorre quando uma das reações da personagem Aurora à morte de Andrei é escrever uma carta para ele e publicá-la no Facebook, em meio às várias postagens sobre o tema que já apareciam em sua timeline:

\begin{abstract}
Abri o laptop, salvei e fechei o arquivo de PowerPoint e, sem pensar muito no que estava fazendo, escrevi uma carta que enviaria a Andrei caso estivesse vivo. Publiquei a carta a Andrei em minha página do Facebook. Ela se perdeu na cascata de postagens a respeito dele que inundavam a internet desde sua morte. Era muito mais do que se podia prever, e não parava, só aumentava. (Galera, 2016, p. 135)
\end{abstract}

Além de atuar de forma efetiva no cotidiano dos personagens - assim como ocorre na vida real -, a tecnologia no livro também aparece como um mecanismo que, de formas distintas, é responsável por revelar detalhes da intimidade de alguns dos personagens, seja para os leitores, seja para outros personagens do romance. Uma visita de Antero a sites pornográficos, por exemplo, é descrita ao longo de quase duas páginas, nas quais são especificados os vídeos que ele assiste e que tipo de cenas procura, detalhando, assim, várias preferências sexuais do personagem.

Já no caso de Aurora, é justamente a internet que será responsável por expor detalhes de sua vida privada, uma vez que ela frequenta e participa de um site de performances eróticas chamado Chaturbate ${ }^{15}$ e acaba tendo que lidar com a possibilidade de que César, um professor que a reprovou no exame de qualificação de seu doutorado na USP, teria sido um dos homens com quem interagiu ou que a observou por meio do site:

15 "Chaturbate é um site onde pessoas podem transmitir performances eróticas ou pornográficas em streaming de vídeo. Dividido em 4 categorias: câmeras de mulheres, câmeras de homens, câmeras de casais e câmeras de transexuais, é possível ver os shows gratuitamente, sem registro e mediante a compra dos chamados tokens enviar ao modelo determinada quantia, que quando acumulada pode ser convertida em dinheiro. Ainda é possível conversar através da plataforma." (WIKIPEDIA, 2017) 
Sempre levei em conta que havia um pequeno risco ao me expor ali, e o risco era parte do atrativo, mas agora precisava lidar com a ideia de que um dos homens que me chamaram de gostosa no chat enquanto eu bebia meu drink com os peitos de fora às duas da madrugada, um dos que me mandaram, por meio da moeda virtual do site, gorjetas que eu nem pedia, e que ao longo dos meses nunca passaram de um punhado de reais no total, ou um dos homens que simplesmente ficaram me espiando um tempo, sem interagir de forma nenhuma, um deles tinha sido o César, que faria parte da minha banca dali a poucos dias. (Galera, 2016, p. 147)

Mas o acontecimento mais revelador nesse sentido diz respeito aos personagens Emiliano e Andrei. Na juventude, eles chegaram a ter um breve envolvimento sexual, mas, na época, Andrei diz a Emiliano que não é gay e eles passam a ter um relacionamento exclusivamente de amizade, apesar do segundo continuar nutrindo um sentimento amoroso - e uma obsessão - pelo primeiro:

Logo ao acordar, depois de tomarmos uma garrafa inteira de suco de laranja em silêncio, meio que fingindo que não estávamos ali, perguntei se poderia procurá-lo de novo dali a dois dias ou na semana seguinte ou em qualquer dia. Ele franziu a testa e mexeu no plástico de um pacote de pão. Percebi que as fatias tinham começado a embolorar e tive certeza de que ele as comeria mais tarde sem perceber. "Eu não sou gay", foi a resposta. (...) Mandei ele se foder e comecei a catar as coisas pra ir embora. Duque tentou minimizar o mal-estar dizendo que tinha gostado da experiência, que, se dependesse dele, continuaríamos conversando e nos tornaríamos amigos. (...) eu sabia que ficaria obcecado pelo Duque ainda por um bom tempo, e que sofreria por mais tempo que o necessário com isso, como de fato ocorreu. A sensação de perda derivada daquele episódio nunca teve fim. (Galera, 2016, p. 74-75)

Quando Andrei é assassinado, Emiliano fica sabendo que ele tinha deixado instruções para que a namorada apagasse toda sua "presença on-line" caso ele morresse, mas desconfia que, apesar de estar tentando, ela não conseguiria fazê-lo totalmente e fica obcecado em encontrar rastros desconhecidos que Andrei pode ter deixado na internet. Depois de procurar em várias redes sociais e sites, testando o nome de usuário do amigo e algumas combinações de senha que acha que ele possivelmente usaria, acaba conseguindo fazer login em um aplicativo de acompanhamento de corrida chamado SprintRun:

Duque treinava quase todos os dias, de acordo com Francine, e havia sido assaltado justamente durante uma de suas corridas noturnas pela cidade. O ladrão tinha levado seu iPhone. Era provável que ele usasse um aplicativo daqueles pra rastrear 
as corridas, e o SprintRun era o mais conhecido. Digitando em modo automático, com a vista já embaçada, fui colocando as senhas e apertando no botão Entrar. Em algum momento, em vez da tela recarregar com o aviso de senha incorreta, abriu-se outra tela cheia de gráficos, menus e jotapegues de gente feliz correndo. Dei scroll pra cima e pra baixo, incrédulo. Eu estava dentro da conta de Duque. Seu nome e foto encabeçavam o box do perfil no canto superior esquerdo. Aquele nariz de judeu e cabeça com calvície precoce, os olhos penetrantes e boca carnuda, a barba por fazer. (Galera, 2016, p. 183)

Emiliano passa então a olhar as rotas que Andrei fazia em suas corridas, acompanhando os percursos que o amigo costumava fazer em Porto Alegre, enumerando as ruas e descrevendo os locais pelos quais ele passava - o que mostra como Galera continua trabalhando com as referências geográficas em suas obras, recriando em detalhes os espaços da cidade - e acaba fazendo uma descoberta sobre essa rotina de corridas:

\begin{abstract}
Pegava a Vinte e Quatro de Outubro até o Parcão, passava pelo meio do parque e seguia pela avenida Goethe e pela rua Silva só até chegar à Protásio Alves. E então algo muito estranho e perturbador ocorria. Em vez de pegar a Protásio à direita e retornar pra José Bonifácio, de onde havia partido, Duque virava à esquerda, corria algumas quadras pela calçada até a Vicente da Fontoura, entrava nessa rua à esquerda, cruzava a Passo da Pátria e parava bem em frente ao meu prédio. Depois disso, dava meia-volta, retornava pela Protásio e seguia a rota mais curta na direção de casa. Fiquei um tempo olhando o mapa, atônito. (...) No dia em que foi morto a tiros por um assaltante, ele tinha desviado da rota pra vir até a frente da minha casa. Estava claro que era um desvio. O próprio desenho do trajeto mostrava isso. Um corpo estranho com o formato da letra $\mathrm{L}$ se projetava do circuito fechado, abandonando as calçadas amplas e parques e adentrando as calçadas estreitas e deterioradas da Protásio Alves, somente pra alcançar a porta do meu prédio e então voltar. (Galera, 2016, p. 185)
\end{abstract}

Essa descoberta - saber que Andrei esteve na porta de sua casa no dia em que foi assassinado - atinge profundamente Emiliano, ainda impactado pela morte do amigo, com quem há anos só conversava ocasionalmente por email. Entretanto, ao continuar esquadrinhando o aplicativo, percebe que aquele não era um evento isolado, que as visitas - que, na verdade, pareciam não passar de uma breve observação da janela de seu apartamento - tinham acontecido várias vezes nos meses anteriores a sua morte: 
Rolando pra baixo a timeline, passei os olhos pelos trajetos das corridas de Duque nos meses anteriores. (...) Em alguns casos, lá estava o desvio que o levava até a frente do meu prédio. Não era muito frequente, mas acontecia. Fui dando scroll. Quatro. Cinco. Seis. Dez vezes. Uma hora parei de olhar (...) Ele nunca tinha tocado o interfone enquanto eu estava em casa, disso eu tinha certeza. (...) Decidi, por falta de alternativa melhor, que os desvios que tomava nas corridas até a frente do meu prédio eram uma necessidade íntima dele. Parte de sua vida secreta, ou seja, dos hábitos que cultivávamos sozinhos e que eram absurdos de qualquer ponto de vista prático mas que pra nós eram absolutamente vitais. (...) Minha vida secreta tinha dessas coisas. A de Duque, de acordo com os registros do aplicativo SprintRun, incluía espiar minha janela de tempos em tempos. Fosse ou não uma interpretação correta, a ideia me apertou o coração com tanta força que meus olhos se encheram de lágrimas. (Galera, 2016, p. 186-188)

É por meio dos rastros deixados na internet por Andrei que Emiliano acaba tendo contato com um aspecto muito particular da vida do amigo, que ele chama de "necessidade íntima". A intimidade, de fato, é um tema fundamental no romance. E, no caso deste livro, ao contrário dos anteriormente analisados Mãos de cavalo e Barba ensopada de sangue, é a narração em primeira pessoa, a partir da perspectiva de Aurora, Antero e Emiliano, que nos permite conhecer o mundo interior dos personagens. Entretanto, mesmo o protagonista-ausente Andrei, tem detalhes de sua intimidade revelados por outros mecanismos.

Isso, de certa forma, também está presente no último capítulo do livro, narrador por Aurora, quando a personagem vai sozinha para um sítio isolado e passa dias lá sem que ninguém saiba (nem mesmo Emiliano, cuja família é dona do lugar), fazendo caminhadas, procurando se distanciar de tudo e de todos. Em uma dessas caminhadas Aurora avista um animal, um veado branco, e o romance se encerra com a personagem tentando, sem sucesso, segui-lo:

Não era a primeira vez que me embrenhava ali, mas os caminhos se bifurcavam e fui me sentindo atraída pela ideia de que era realmente possível me perder naquele lugar para nunca mais ser vista. (...) Cada passo me afastava um pouco mais da minha família, do meu doutorado, dos meus colegas de departamento, dos meus poucos amigos, dos meus poucos objetos, dos meus rastros virtuais. Eu procurava abrir todos os meus sentidos para a clareira, para o legado fantasmagórico de seus antigos moradores humanos, para o cheiro rochoso da brisa suave que agitava as folhas, para os zumbidos e vibrações daquele recanto que se oferecia a mim e a mais ninguém, que fazia de mim quem eu era naquele instante, quando um vulto esbranquiçado roçou meu campo de visão. Meu coração acelerou e, sem mover nada além da cabeça, inspecionei a vegetação ao meu redor até que vi o animal. Entre as árvores, um veado branco pisava cauteloso, me espiando de lado, assimilando minha presença ao mesmo tempo que eu assimilava a dele. A mata não 
se agitava nem produzia ruído algum enquanto ele passava. Ele não parou, mas passou devagar o bastante para que eu o observasse. Tinha os olhos avermelhados. $\mathrm{O}$ corpo branco era salpicado de marrom-claro e as galhadas eram curtas e negras, recobertas de uma penugem cinza. Eu tinha certeza do que estava vendo. $\mathrm{O}$ veado se afastou de mim sem nenhuma pressa. $\mathrm{O}$ branco foi se apagando no breu da mata nativa até sumir. Fiquei um instante indecisa. Segui na direção que ele havia percorrido, tentando refazer seus passos, mas não voltei a avistá-lo. Ele tinha descido para o fundo do vale, lá onde a mata se adensava ainda mais. (Galera, 2016, p. 200-202)

Na época do lançamento de Meia noite e vinte, Daniel Galera usou seu Tumblr $^{16}$ para responder perguntas dos leitores. Sobre o final do romance, respondendo a um leitor que perguntou se esse encontro da personagem com o animal teria algum significado relacionado a uma "imagem de esperança", ele comentou: "Aquele encerramento é acima de tudo um momento de intimidade. Tem uma frase do Timothy Morton que quase foi epígrafe do livro: 'Sem um mundo, o que resta é intimidade'. É por aí” (Galera, 2016).

No prefácio do livro Scenes of Intimacy: Reading, Writing and Theorizing Contemporary Literature (2013), Jennifer Cooke observa que

Certain examples of contemporary literature are engaging with what still often remains unspoken in many arenas: the intimacies we find deeply uncomfortable, sometimes chaotic, and that we prefer not to articulate or perhaps even to think about too closely or too frequently. (Cooke, 2013, p.5)

Esse pensamento vai ao encontro de muitas das questões que perpassam não só Meia noite e vinte, como também Mãos de cavalo e, em alguns aspectos, Barba ensopada de sangue. Seja por meio do discurso de narradores colados a seus protagonistas, pela visão dos próprios personagens-narradores ou até mesmo através de outros mecanismos - como a revelação da "necessidade íntima" de Andrei feita pelo aplicativo após sua morte -, a obra do autor tem lidado, por meio de estratégias distintas, com o mundo interior de seus personagens e seus dilemas mais particulares, caracterizando-se como mais do que um realismo que

\footnotetext{
${ }^{16}$ O Tumblr é uma plataforma digital que pode ser descrita, em linhas gerais, como uma mistura de rede social e blog/site pessoal. Daniel Galera utiliza o seu principalmente para postar imagens em geral e passagens de textos de outros autores. Além de publicar as perguntas dos leitores e suas respostas sobre Meia noite e vinte, ele colocou também em seu Tumblr, antes do lançamento, alguns trechos então inéditos do romance. O endereço é: 〈http://ranchocarne.tumblr.com〉.
} 
trabalha apenas com construções externas ou com questões que caracterizam o realismo psicológico, como reflexões ou monólogos internos, e sim desvelando, por meio de diferentes métodos e de forma intensa, o universo íntimo de seus personagens.

Muitos outros temas e questões poderiam ser levantados sobre a obra de Daniel Galera, entretanto, minha leitura, conforme procurei expor no início deste capítulo, foi delineada por alguns pontos principais. Acredito que tenha sido possível passar por pontos fundamentais para este trabalho, principalmente relacionados ao modo como o autor trabalha o mundo interior dos personagens e como constrói o mundo exterior a partir da visão íntima desses mesmos personagens.

Se nos seus primeiros livros observamos, inicialmente, a procura e o ensaio de um estilo, é possível perceber, a partir de Mãos de cavalo, uma dicção que se desenvolve e se articula no sentido de desdobrar possibilidades de criação e representação que buscam a elaboração de mundos ficcionais que não apenas são verossímeis, mas, além disso, se projetam de forma crível a partir de experiências muito particulares.

E são justamente as estratégias que possibilitam esse movimento que procurei mostrar e analisar neste capítulo. Acredito que seja possível, ao mesmo tempo, identificar uma linha de força constante que almeja essa projeção e a sofisticação e diversificação das estratégias ao longo da obra do autor.

O próximo passo, então, é abandonar, por enquanto, a obra de Galera, e se enveredar (ou mergulhar) nos livros de outra autora, que guardam semelhanças e diferenças com os que foram analisados até aqui, o que será feito no próximo capítulo. 


\section{3 \\ O segundo mergulho}

Assim como o anterior, este terceiro capítulo tem a intenção de realizar uma imersão, desta vez na obra da escritora Carol Bensimon, com o objetivo de buscar possibilidades que surgem a partir dessas leituras e que, de algum modo, possam vir a estar ligadas à hipótese dessa tese.

A ideia aqui é analisar questões levantadas pelos livros da autora que, de alguma forma, estejam relacionadas às características do realismo íntimo, como temas, estratégias e outros elementos que poderão surgir a partir dessas leituras, procurando desvendar de que modo a autora trabalha com a criação de um universo verossímil a partir do interior de seus personagens e, ainda, de que maneira os cenários exteriores ajudam a definir, construir e delinear personagens e narrativas.

No entanto, algumas questões precisam ser ressaltadas: Carol tem uma obra de ficção até agora menos extensa do que a de Daniel Galera. Por outro lado, ela tem uma atuação como cronista e colunista em veículos como o site do jornal Zero Hora e o blog da editora Companhia das Letras, com alguns textos relacionados a questões ligadas à criação artística e literária. Além disso, Carol cursou mestrado em Escrita Criativa na PUC-RS, defendendo, em 2008, dissertação sobre o personagem ausente na literatura, trabalho esse que se constitui de uma discussão teórica sobre o tema, seguida por uma primeira versão do romance Sinuca embaixo d'água, que pouco tempo depois foi um dos vencedores da bolsa de estímulo à criação literária da FUNARTE, sendo publicado pela Companhia das Letras em 2009.

Devido às razões elencadas acima, decidi efetuar neste capítulo um pequeno desvio, estendendo a análise, em um ou outro momento, também para a produção não-ficcional de Bensimon, por acreditar que essa produção seja capaz de, em algumas situações, iluminar alguns aspectos da obra ficcional da autora. 
Antes de entrar propriamente na análise dos livros, trago uma breve apresentação da autora em questão: Carol Bensimon nasceu em Porto Alegre, em 1982, onde vive hoje, depois de ter morado em Paris por dois anos e passado alguns períodos mais breves nos Estados Unidos. Participou do Insanus, conglomerado de blogs sobre cultura, tecnologia, entre outros temas, no qual manteve, entre 2004 e 2009, o blog Kevin Arnold para dois, onde publicava textos e observações pessoais, além de comentários tanto sobre o processo de criação como sobre os desdobramentos dos lançamentos de seus primeiros livros.

A autora publicou três livros de ficção: Pó de parede (2008), composto por três contos (ou novelas), e os romances Sinuca embaixo d'água (2009) e Todos nós adorávamos caubóis (2013). Lançou ainda Uma estranha na cidade (2016), coletânea de crônicas sobre temas como a vida urbana, a tecnologia e dilemas geracionais ao ensaio. Algumas das crônicas de Uma estranha na cidade foram publicadas anteriormente no jornal Zero Hora.

Alguns contos de Carol também foram publicados em veículos como as revistas Bravo e Ficções, o jornal Folha de São Paulo e o site Bestiário. Antes do lançamento de Todos nós adorávamos caubóis, o primeiro capítulo do romance figurou em 2012 na revista Granta: os melhores jovens escritores brasileiros, com o título de "Faíscas". A autora participou ainda de antologias de contos como Ficção de polpa - Crime! (2011), Rock book - Contos da era da guitarra (2011) e Histórias femininas (2011).

Bensimon atua ainda como tradutora do francês, tendo traduzido as versões em quadrinhos de obras como $\mathrm{O}$ estrangeiro, $\mathrm{O}$ retrato de Dorian Gray e $\mathrm{Na}$ colônia penal, entre outros. Ocasionalmente, ministra oficinas de criação literária em diferentes cidades do Brasil, geralmente voltadas para aspectos estruturais da elaboração de romances, com foco em questões como a construção de cenas e a articulação dos elementos da narrativa.

Meu primeiro contato com a obra de Carol Bensimon se deu devido à internet, mais especificamente ao Twitter, justamente através de Daniel Galera, que divulgou em seu perfil o lançamento de Sinuca embaixo d'água, que aconteceria dali a alguns dias. Sem nunca ter ouvido falar em Carol Bensimon, 
procurei algumas informações sobre a autora na internet e me deparei com o conto "Venezianas azuis", publicado na revista Bestiário em 2005, e com um blog (que não se encontra mais online) no qual a escritora relatava o processo criativo do livro que seria lançado, uma espécie de - na definição da própria Carol - making off do livro.

Adquiri Sinuca embaixo d'água assim que foi lançando e, desde as primeiras páginas, chama atenção no livro o trabalho com a linguagem, usada de modo a construir uma atmosfera melancólica que permeia todo o romance. E essa melancolia está ligada a uma das questões mais significativas do livro, o pressuposto da protagonista-ausente, sobre o qual toda a trama é construída, conforme procurarei mostrar mais à frente neste trabalho.

Foi depois da leitura de Sinuca embaixo d'água que tive contato com seu primeiro livro, Pó de parede, que reúne três contos, "A caixa", "Falta céu" e "Capitão Capivara”. A primeira narrativa foi a que mais me chamou a atenção na época, principalmente devido à dedicação da autora à linguagem, imprimindo um estilo coloquial e, ao mesmo tempo, denso, como tentarei detalhar a seguir, construindo uma ambientação física a serviço dos temas da narrativa.

Quatro anos separaram o lançamento de Sinuca embaixo d'água e o livro seguinte de Bensimon, Todos nós adorávamos caubóis. Ao longo desse tempo, entretanto, a autora publicou outros textos em veículos diversos e em várias ocasiões comentou em suas redes sociais ou em seus textos no blog da Companhia das Letras questões relativas ao livro que estava escrevendo, dividindo com os leitores inclusive alguns dos dilemas dessa escrita.

O lançamento de Todos nós adorávamos caubóis aconteceu em 2013 e foi acompanhado por um booktrailer ${ }^{17}$, cujas cenas se passam justamente nas locações do livro sendo visitadas por duas mulheres, que representam as protagonistas - e uma delas, no booktrailer, é a própria Carol -, e uma playlist ${ }^{18}$ com canções de bandas e artistas como Led Zeppelin, Kurt Vile, Wild Nothing,

\footnotetext{
17 O booktrailer pode ser assistido no link https://youtu.be/FHqGhTVGMqk.

18 A playlist pode ser encontrada no link https://www.mixcloud.com/carolbensimon/todosn\%C3\%B3s-ador\%C3\% A1 vamos-caub\%C3\%B3is/.
} 
M83 e Lana Del Rey, alguns citados no livro e outros que, de acordo com a autora, fizeram parte do processo de escrita.

Pouco antes do lançamento, Carol postou no seu perfil no Facebook um álbum com várias fotos de viagens que fez com amigos ao interior do Rio Grande do Sul e, apesar de não ter incluído nesse álbum nenhum comentário sobre o livro, os leitores posteriormente puderam reconhecer nas fotos vários dos lugares que aparecem nas páginas do romance.

Essas estratégias - o booktrailer, a playlist, as fotos - transformaram a experiência de leitura de quem, assim como eu, estava acompanhando os desdobramentos do lançamento Todos nós adorávamos caubóis, fazendo com que ela ultrapassasse o contato com o livro, já que, além da leitura, era possível ter outros tipos de proximidade com a trama, cenários e personagens.

A partir dessa apresentação, o trabalho se direcionará então para a análise das obras de Carol Bensimon. Assim como no capítulo sobre os livros de Galera, aqui a leitura crítica também será feita seguindo uma ordem cronológica das publicações de Bensimon, procurando identificar e ressaltar características dessas obras por meio de análises que eventualmente se encontrarão com questões teóricas que, acredito, possam vir a clarear e desdobrar determinados aspectos da obra da autora.

\section{1.}

\section{A arquitetura interior de Pó de parede}

Publicado pela Não Editora em 2008, Pó de parede traz três narrativas que, apesar de bastante distintas entre si, abordam temas próximos, relacionados a episódios centrados na vida de personagens jovens que, de alguma forma, estão passando por mudanças ocasionadas por fatores diversos, como no caso de "Falta céu", no qual é a construção de um novo condomínio em uma pequena cidade "Acontece que nasceram numa cidade bem pequena entre duas mais ou menos grandes, um tipo de coisa ruim para o conformar-se, porque assim tinham toda a 
estrada para olhar, e olhavam" (p. 61) - que irá modificar radicalmente o cotidiano dos moradores, mudanças essas que coincidem com as descobertas e dilemas do início da adolescência dos personagens Lina e João.

Esse tema também aparece no primeiro conto do livro, intitulado "A caixa", que narra alguns episódios ligados ao crescimento e amadurecimento de três improváveis amigos de infância, Alice, Tomás e Laura, e se apresenta como um texto diretamente filiado ao que Carol Bensimon virá a produzir nos seus livros seguintes, com um estilo que marca toda a produção posterior dessa escritora.

Um primeiro ponto que pode ser levantado em uma análise deste conto é justamente o modo como a autora parece trabalhar a linguagem no sentido de criar uma espécie de proximidade com o leitor. Existe uma alternância entre um narrador em terceira pessoa e uma narradora em primeira pessoa, a personagem Alice. Enquanto o primeiro narra os trechos que se passam em 2006 e 2007, é através do olhar em primeira pessoa de Alice que vemos os acontecimentos de 1991, 1996 e 1997 - e, quando a personagem assume a narração, há uma mudança na dicção, de modo a torná-la ainda mais pessoal, em passagens como "Pegue um dia de calor. O bairro está fervendo e se preparando para as férias. Eu dentro do ônibus escolar." (p. 21) e na passagem que a narradora explica um detalhe da arquitetura da casa onde mora, também se dirigindo a um possível interlocutor (ou leitor):

(...) em volta da casa nós temos um muro de tijolos de cerâmica furados. O Sr. Kowalski chama isso de combogós. Acho que a ideia é que possamos ver o mundo, mas que o mundo não possa nos ver. O que na verdade acontece é que também não vemos coisa alguma. Experimente com esses furos. É como um quebra-cabeça de mil peças que você decide montar no terraço e a metade das peças sai voando para sempre num começo inesperado de tempestade (Bensimon, 2008, p. 27-28)

Existe também uma espécie de presentificação do tempo passado na narrativa. Em alguns momentos da narração de Alice, é como se os eventos narrados estivessem ocorrendo no exato momento em que são enunciados - como na passagem anterior em "o bairro está fervendo" e no trecho "Então estou no meu quarto, com o convite rosa de Laura na mão" (p. 27). Em outras passagens, há uma oscilação nos tempos verbais que desloca o tempo das ações, como em 
“(...) Laura levanta de repente da sua poltrona e chega bem perto de mim. Se ajoelha. Agora ela está pertíssimo e vai começar a falar muito baixo" (p. 39) ou quando a narradora situa a ação em um tempo passado, antecipando o que acontecerá no futuro e misturando planos e impressões temporais relativos a si mesma, à casa e à personalidade e aos hábitos de sua família:

Eles estavam ficando velhos, meu pai e minha mãe, e suas ideias também. Haviam se conhecido porque montaram as barracas uma ao lado da outra, na beira de um penhasco, o tipo de acontecimento onde todos dançavam pelados, pelo menos na minha imaginação. (...) Haviam tomado ácido. Um dia me encorajariam a tomar. (...) Agora já era noventa e um, gente com camisa de flanela andando de cabeça baixa. Logo eu teria as minhas também. A minha cabeça pelo menos já olhava para o chão, mas na minha casa era sempre sessenta. Lá fora ela dizia pelas paredes que ainda acreditava num tipo de futuro excêntrico. Lá dentro os discos cantavam que o mundo estava mudando, canções de trinta anos atrás com esperanças mofadas (Bensimon, 2008, p. 19-20)

Esse deslocamento e essa presentificação contribuem para a estrutura nãolinear do conto - os trechos passados em 1991 ou 2006 se alternam com o que aconteceu em 1996 ou 2007 sem uma ordem cronológica muito rígida -, alternando o passado e o presente dos personagens, fazendo com que as idas e vindas na narração funcionem no sentido de ir montando aos poucos a trama que se desenrola a partir do crescimento e do amadurecimento dos personagens Alice, Tomás e Laura.

Já em "Capitão Capivara" a narrativa é linear e conta a história de uma jovem escritora, Clara, que deixa a casa da família para trabalhar em um hotel de luxo, incorporando o papel do mascote Capitão Capivara, que tem a função de entreter as crianças que frequentam o hotel. No mesmo local está hospedado Carlo Bueno, um famoso escritor de histórias de detetive, e os caminhos dos dois vão se cruzando ao longo da narrativa de forma ocasional, assim como o foco narrativo, que em alguns trechos é de Carlo e em outros de Clara. O conto gira em torno dos motivos que levaram os personagens para aquele hotel e dos detalhes do cotidiano de ambos naquele local, entretanto, não há um clímax ou uma solução da trama que termina, inclusive, no meio de uma frase. 
Um elemento que se destaca neste conto é a construção de cenários e isso ocorre de três modos distintos e em três níveis diferentes. O primeiro relacionado à própria descrição do hotel, visto a partir da perspectiva um tanto sarcástica de Clara, que ressalta a obsolescência da decoração e da construção no geral:

O hotel estava na parte mais alta da montanha, a cereja no topo do bolo. Tão alto que em muitos dias as nuvens ficariam ainda abaixo dele e, pelos janelões da sala da lareira, os casais esticados nos sofás não veriam coisa nenhuma. Era comprido, com três andares, cheios de arcos sobre cada uma das suas janelas e um pouco fora de moda, porque talvez não entendesse que ia durar tanto e se construiu como se fosse ser para sempre setenta. Assim eu logo descobriria que o anfiteatro era cheio de um constrangimento visual para aquelas pessoas que, como eu, se ligavam aos detalhes, com suas paredes atapetadas e cinzeiros embutidos nas poltronas, que bem mereciam um registro fotográfico para que nos convencêssemos que sim era verdade, eles ainda estavam ali, e nos quartos havia cadeiras feitas de imitação de couro de cobra e azulejos com a cabeça da esfinge. (Bensimon, 2008, p. 95-96)

A segunda perspectiva é por meio do escritor Carlo Bueno, que está no hotel justamente para escrever um romance que se passe ali, transformando o local no cenário de um de seus famosos livros de detetive, conforme ele explica para um dos empregados:

Então expliquei como pude explicar, embora a mim mesmo ainda soasse um pouco estranho: que meu editor copiava muito o que se fazia pelos Estados Unidos, que achava que o romance estava morrendo e as vendas caíam vertiginosamente e numa feira ouvira muito falar de merchandising literário, que era basicamente escrever um livro e nesse livro citar marcas que então pagavam para estarem ali no livro. Como quando bebem café no meio da novela e dizem Ó, que café ótimo, eu nunca tomei um café igual e etc., close na caixa do café. Pois o hotel me paga pra ficar aqui, Edgar. Eu fico aqui escrevendo o livro e o livro vai se passar no hotel e as pessoas vão ler o livro e vão ter vontade de vir aqui para o hotel. Pelo menos é esse o plano. (Bensimon, 2008, p. 104)

Em um terceiro nível, os cenários estão presentes como uma espécie de decoração externa um tanto quanto improvável: a partir do hotel, é possível divisar um vale onde existem algumas casas que compõem aquela vista e a narradora Clara imagina (ou suspeita) que elas não sejam de verdade, apelidandoas de "falsas casinhas": 
(...) enquanto isso eu olhava para trás dele, onde se podia enxergar o vale e as casinhas do vale, e fiquei brincando de imaginar que na verdade ninguém morava naquelas casinhas, que elas existiam apenas para serem admiradas através das grandes janelas do hotel, e quem sabe algum funcionário descia até lá diariamente para fazer uma fumaça bonita sair pelas chaminés (Bensimon, 2008, p. 96-97).

Ao final do conto, essa impressão se confirma quando a narradora desiste do emprego, foge correndo do hotel e, sem saber o que fazer em seguida, se dirige para as tais casas do vale. O conto se encerra no meio de uma frase, quando a narradora revelaria o que é encontrado dentro da terceira casa, entretanto, o leitor fica sabendo que as duas primeiras estavam vazias, atuando, portanto, assim como Clara desconfiava, apenas como uma paisagem cenográfica, uma espécie de decoração na vista que os hóspedes tinham a partir do hotel: "Olhei as casas na minha frente, tão grandes agora. E cheguei àquelas casinhas com jeito de quem espera ser convidada para o almoço. Abri a primeira e vazia. Abri a segunda e vazia. Abri a terceira e" (p. 122).

Essa questão da construção de cenários também aparece de modo distinto no já citado conto "A caixa", que tem como um de seus temas centrais a arquitetura, presente na narrativa de maneiras diferentes e diversas: além de ser a profissão que Alice escolherá no futuro e ser citada por meio de referências a trabalhos de Le Corbusier e Frank Lloyd Wright, o campo semântico referente a esse tema é, em algumas ocasiões, utilizado pela autora na construção de metáforas para descrever alguns cenários:

Tomás esperava Alice voltar nessa noite que era um pouco todas as noites de sua infância. Em volta, o escuro e o sono do bairro criavam uma falsa harmonia, todo detalhe escondido, todo defeito na sombra. E como o dois-cinco-um estava no topo de uma ladeira, a vista então diagonal das ruas bem traçadas com as casas todas iguais, Tomás diria que as árvores poderiam ser de esponja, as paredes cortadas com estilete, tudo maquete, onde os lugares têm aquela perfeição que não alcançam nunca quando se tornam reais (Bensimon, 2008, p. 14-15)

Entretanto, existe ainda outra presença da arquitetura na narrativa que atua de forma mais essencial, unindo a questão temática e formal e culminando em uma associação muito particular entre as construções e os personagens, como no caso da personagem Alice e sua casa, a "caixa” que dá título ao conto: 
A casa de Alice no fim da descida como se de repente mais um pedaço da memória de Tomás houvesse clareado. Suas paredes muito brancas, um cubo perfeito, agora espalhavam a luz, criando um halo que a separava de todo o resto. Aquela casa sempre fora a mais estranha e a mais polêmica de todo o bairro (...) E bem no meio desse cubo de influências modernistas, ideia de um arquiteto louco e ambicioso, havia um jardim, furando com precisão o concreto, e daí os muitos verdes das plantas do pai de Alice dispostos pelas beiradas. Sem telhas ou nada que lembrasse o formato tranquilizador de um sonho padrão, com muito vidro de cima a baixo e também esquadrias de alumínio, embora o excesso de transparência fosse compensado por um muro de tijolos levemente vazados, Tomás começou a pensar o quanto de Alice era produto daquela inadequação (Bensimon, 2008, p. 15)

Desde o início do conto, algumas nuances da personalidade de Alice são ligadas à peculiaridade de sua casa. Ambas são descritas como "estranhas", “esquisitas”, “deslocadas”. Nesse sentido, a casa figura não só como uma espécie de personagem dentro da narrativa, mas como um referencial a partir do qual se ergue também a construção da personagem:

\begin{abstract}
Mas agora a minha casa já está nas janelas do ônibus e esse é o momento em que eu fico mesmo constrangida, com a sensação bem nítida de que todos estão olhando o belo conjunto formado por Alice, a estranha do colégio descendo do ônibus, e a sua casa dos Jetsons que só faltava ter esteiras rolantes levando até a porta. Mas rampas tem. Minha sorte é que ninguém vê, a não ser que sobrevoem com um helicóptero ou subam num telhado vizinho, porque estão por dentro, no nosso furo-jardim, levando direto para os quartos no segundo andar sem que a gente tenha que necessariamente cruzar a sala. Ahá, o Sr. Kowalski, caríssimo arquiteto, pensou em tudo o que podia. De qualquer maneira, não precisa nem saber a respeito das rampas para achar a nossa casa uma verdadeira coisa de louco. O motorista diminui a velocidade e, nos bancos de trás, os garotos fazem silêncio (Bensimon, 2008, p. 25)
\end{abstract}

Em A poética do espaço (2008), Bachelard empreende uma discussão que perpassa por vários temas, mas que tem como cerne dois pontos principais: o espaço e a intimidade, questões que são desdobradas, inicialmente, a partir de uma reflexão que o autor faz sobre a importância da casa para a memória e para a vida íntima, afirmando, por exemplo, que "[t]oda grande imagem é reveladora de um estado de alma. A casa, mais ainda que a paisagem, é um estado de alma. Mesmo reproduzida em seu aspecto exterior, fala de uma intimidade" (2008, p. 243).

No trecho do conto reproduzido acima, Alice se sente aliviada porque os colegas não conhecem sua casa por dentro, entretanto, sabe que o exterior da casa, 
a própria existência daquela construção e o fato de morar nela já são suficientes para que, de algum modo, as outras crianças percebam algo sobre a intimidade dos que ali habitam.

A casa é, portanto, elemento que atua em um nível figurativo exterior, como cenário, mas também referencial, a partir do qual se desvelam significações inerentes ao mundo interior e íntimo de Alice. Existe, então, uma dupla significação na narrativa relacionada à casa e aos personagens: ao mesmo tempo que é a partir da contemplação (e do estranhamento) da casa que os colegas de escola e vizinhos - "Você pode ouvir os vizinhos sussurrando. A nossa casa é uma coisa que os deixa incomodados. Não se pode ter uma vida normal dentro dessa casa, é o que eles pensam" (p. 25) - especulam sobre a intimidade da família da Alice, a narrativa a todo momento deixa indícios que associam a personalidade da personagem às singularidades daquela casa.

Carol contou inicialmente no blog Kevin Arnold para dois e, posteriormente, na sua coluna no blog da Companhia das Letras sobre o episódio no qual tentou entrar em contato com a família que morava na casa que inspirou a "caixa", descrita em detalhes no conto, mas nunca visitada pela autora:

\begin{abstract}
Na primeira história [do livro Pó de parede], há uma casa modernista e, bem, digamos que ela existe de fato, ou ao menos a casa que acabou por inspirá-la, que ficava perto do meu trabalho, e cujos ocupantes eu jamais vira. Quando o livro ficou pronto, escrevi à mão uma carta ("Olá, família"), adicionei um exemplar do livro, coloquei tudo num envelope de papel pardo e, zás, por baixo da porta. Passaram-se meses e ninguém fez contato. Um belo dia, quando eu já não morava mais em Porto Alegre, recebi um e-mail da proprietária da casa, convidando-me para uma visita. Lamentei o fato de que não estava mais na cidade, e prometi que ia entrar em contato em outra ocasião. Queria tanto conhecer aquele pátio interno que eu tinha imaginado. Mas então o tempo passou, o e-mail sumiu, perdi as referências. Talvez tenha sido melhor assim. (Bensimon, 2011a)
\end{abstract}

No texto ela fala justamente sobre essas possíveis coincidências entre realidade e ficção, discutindo o quanto de matéria real há em sua produção ficcional. No caso da "casa modernista", é interessante observar como Carol partiu do exterior visível para construir justamente um interior invisível ao qual ela não tinha acesso e ambos se constituíram, no conto "A caixa", como fio condutor do universo íntimo dos personagens da narrativa. Essa tensão entre um 
cenário exterior real que se reflete no universo íntimo ficcional dos personagens também está presente no livro posterior de Bensimon, que será analisado na próxima seção deste capítulo.

\section{2. \\ Sinuca embaixo d'água e a protagonista que não estava lá}

O primeiro romance de Carol Bensimon, Sinuca embaixo d'água (2009), parte de uma premissa peculiar: a do "protagonista ausente". Ao colocar o início da narrativa após o acidente de carro que mata Antônia, a autora tira de cena a personagem ao redor da qual gira a trama do livro, construindo justamente nesse vazio uma trama sobre perda e ausência.

Conforme colocado no início deste capítulo, o romance, inicialmente, fazia parte da dissertação de mestrado da autora no curso de Escrita Criativa, sendo antecedido por uma reflexão teórica justamente sobre o tema do personagem ausente. A dissertação, intitulada A personagem ausente na narrativa literária, é apresentada como uma reflexão sobre a definição do personagem ausente e sua participação no universo da narrativa e, inicialmente, a autora elenca exemplos da ocorrência desse tipo de personagem, citando obras como $O$ grande Gatsby (1925), livro no qual a aparição de um personagem central é retardada, e Esperando Godot (1952), peça em que o personagem do título nunca aparece.

A partir disso, Carol delineia o que chama de "condições para a ausência", definindo, a partir delas, quais seriam as circunstância essenciais que envolvem a existência de uma personagem ausente na narrativa literária:

a) A personagem ausente é constantemente referida pelas outras personagens.

b) A personagem ausente pode ser evocada através de objetos, como fotografias.

c) A personagem ausente é parte da história, mas não da trama.

d) A personagem ausente não está em cenas, mas está em sumários.

e) A personagem ausente não age, mas sua ausência motiva os outros personagens a agirem.

f) A personagem ausente, portanto, faz parte do conflito da narrativa. (Bensimon, 2008, p. 13) 
Todas essas condições são atendidas por Antônia em Sinuca embaixo d'água; entretanto, mais do que apenas uma personagem do romance, ela pode ser vista como uma protagonista, uma vez que, apesar de não estar presente na trama, ou seja, no desenrolar dos episódios que constituem o enredo, toda a história do livro gira em torno dela e de sua ausência.

É Antônia que liga os outros personagens e narradores do romance, como seu amigo Bernardo, o irmão Camilo e o dono do bar que ela frequentava, Polaco. Outros narradores ocasionais também aparecem no romance e suas participações estão sempre de algum modo conectadas à morte de Antônia e seus desdobramentos, como Lucas, uma criança que escuta o acidente, Helena, uma jornalista que estava de plantão no dia em que Antônia morreu, e Gustavo, um publicitário que está participando de uma campanha para a prevenção de acidentes de trânsito. É a partir das memórias relativas a Antônia e dos acontecimentos desencadeados por sua morte que esses personagens irão se interligar e são esses elementos os catalisadores de suas narrativas.

A estratégia é próxima àquela usada posteriormente por Daniel Galera em Meia noite e vinte, entretanto, em Sinuca embaixo d'água, a trama está mais intrinsecamente ligada à figura de Antônia, sem maiores desdobramentos que não estejam diretamente relacionados a ela.

Neste romance, as descrições são bastante minuciosas, e mais que apenas descrever, também atuam como indícios do estado emocional dos personagens a partir da ausência da protagonista. O personagem Bernardo, por exemplo, talvez um dos mais afetados pela morte de Antônia, se preocupa com todos os detalhes de cada cena que presencia, colocando em cada objeto significados que sempre acabam por estar ligados à sua história pessoal com a amiga - "Há algo de estúpido aí, no fato de um livro durar mais do que uma pessoa" (p. 85) - e que, inevitavelmente, o fazem pensar na morte dela:

Dentro da minha mochila, a cinco ou seis metros de mim, estão as obras completas de T. S. Eliot, com meu nome na primeira página, e não foi na sala de aula que veio a vontade de ler, mas em Portrait of a lady pela boca de Antônia. Posso ir até o livro agora, e posso tocá-lo, mas Antônia não pode mais, nem tocar, nem ler, nem declamar Portrait of a lady com seu inglês às vezes descambando para um sotaque 
do Alabama que me fazia prender o riso, e eu não tenho a menor chance de tocar outra vem em Antônia (Bensimon, 2009, p. 85)

Essa concentração de atenção no objeto e sua associação com o modo como o personagem, a partir do livro, sente a ausência física de Antônia é interessante principalmente porque pode ser associada a outra questão abordada no já citado texto de Bachelard, que observa que

[d]ar seu espaço poético a um objeto é dar-lhe mais espaço do que aquele que ele tem objetivamente, ou, melhor, é seguir a expansão de seu espaço íntimo. (...) Parece então que é por sua "imensidão" que os dois espaços: o espaço da intimidade e o espaço do mundo se tornam consoantes. (Bachelard, 2008, p. 328)

Já no caso de Gustavo, é uma fotografia que trará um lampejo da presença de Antônia, causando uma reação externa a partir do desdobramento íntimo que essa lembrança ocasiona, o que acontece no meio de uma reunião de trabalho sobre uma campanha publicitária educativa que deveria abordar a violência no trânsito, quando ele se depara com a foto da personagem, que conhecia da faculdade. A partir do momento que visualiza a imagem de Antônia, ele não consegue mais participar da discussão sobre a campanha, nem sequer prestar atenção no que está sendo conversado entre sua equipe e os clientes, o que faz com que a reunião seja um fracasso.

(...) tudo estaria bem se ela não tivesse me mostrado uma foto da Antônia, e daquele tamanho e com aquela expressão, porque eu conseguia lidar muito bem com fotos três por quatro, quando eram só essas sobre a mesa. Aqueles rostos sérios, programados para não piscar nem sorrir, parecem tão anônimos que somos levados a crer que é normal que morram. Mas depois havia fotos maiores, gente em plena atividade, em plena vida, intensamente feliz nos seus momentos mais prosaicos. E havia Antônia e uma menina, em close, e por isso fiquei pensando no seu rosto pintado na última greve e em todos os momentos que podiam ser fotos mas não eram, e de que seria necessário guardá-los só na memória, até que eles se apagassem por causa de uma nova senha do banco. (...) Eu estava fora da briga agora, impotente, eu havia perdido, uma peça posta fora. (Bensimon, 2009, p. 6566) 
Essa passagem também ilustra, assim como o livro ao qual Bernardo se refere, o modo como alguns objetos atuam como elementos que reavivam a todo tempo nos personagens a lembrança da ausência de Antônia. Nesse sentido, a reação de Gustavo diante da imagem da personagem remete a uma afirmação de Barthes sobre a fotografia, de acordo com a qual:

A foto é literalmente uma emanação do referente. De um corpo real, que estava lá, partiram radiações que vêm me atingir, a mim, que estou aqui; pouco importa a duração da transmissão; a foto do ser desaparecido vem me tocar como os raios retardados de uma estrela. (Barthes, 1984, p. 121)

Esse movimento de transmissão e de contato, mesmo que ilusório, também ocorre no livro a partir de outros movimentos que conjugam elementos exteriores e a intimidade dos personagens. A cidade onde a história se passa nunca é nomeada, mas é possível identificar algumas pistas que remetem a Porto Alegre, como a frequente referência que alguns personagens fazem ao lago próximo ao bar do Polaco, frequentado por Antônia. O lugar foi diretamente relacionado pelos leitores do livro que conhecem a cidade ao Guaíba e a um bar próximo, impressão confirmada pela autora quando comenta algumas recorrências de contato entre o real e o ficcional em suas obras: "O outro caso partiu da relação entre o fictício bar do Polaco, do Sinuca embaixo d'água, com o antológico Timbuka, bar portoalegrense às margens do Lago Guaíba. Jamais tive problema em admitir que um era o gêmeo do outro" (Bensimon, 2011a).

Além do lago e do bar, outros espaços da cidade atuam como elementos que de algum modo evocam a ausência de Antônia. O local do acidente de carro é um exemplo disso. Bernardo resiste, mas acaba retornando ao lugar onde o carro da amiga se chocou violentamente contra um poste, resultando em sua morte, tentando refazer o caminho traçado por Antônia e, aparentemente, procurando o que poderia ter motivado a tragédia:

Eu deveria entrar à direita nessa esquina se quisesse ir para casa, mas pego a esquerda, fingindo que não sei para onde vou (...) Dirijo por ruas pequenas, com casas e edifícios de no máximo cinco andares. Paro nas placas de pare e olho para os dois lados (...) Logo mais vou chegar na descida, mas então dirijo devagar para poder ver melhor. É tão íngreme que na verdade não se vê a descida em si, mas 
apenas um final abrupto, que dá a sensação de que a rua interrompe num ponto e de uma hora para a outra (...) Ando a vinte e cinco quilômetros por hora. Todos os carros me ultrapassam. Eu os observo. Quando começam a descer, é como se desaparecessem. Então logo é minha vez. A rua já se inclina uns cem metros antes, mas de forma muito sutil, e de repente você está naquele ponto, naquele degrau, naquele precipício (...) Desligo o som. Dobro duas vezes á direita e estou lá em cima de novo. Estaciono e desço. Fico observando o movimento e, na traseira dos carros, as luzes vermelhas do freio, que se acendem invariavelmente no mesmo ponto da rua. Um reflexo condicionado. O que Antônia pode ter feito de diferente, e por quê? (Bensimon, 2009, p. 48-49)

A geografia da cidade, com suas ruas, esquinas, bares e praças, parece se tornar um emaranhado de locais que remetem os personagens a memórias relacionadas a Antônia e, consequentemente, sua morte. Isso ocorre com o já citado bar do Polaco, por onde transitam, por exemplo, Bernardo e Camilo, acostumados a frequentar o bar com a protagonista, que retornam ao local recordando episódios que ocorreram por ali no passado com a presença dela, para concluir que "Antônia não virá nesta noite, e em nenhuma que ainda está para chegar" (p. 21).

A casa onde Antônia morava e seus detalhes também estão presentes nos livro - "Antônia ainda era uma garotinha quando cheguei aqui, parada na frente de casa e olhando seu cata-vento girar (...) o problema é que ela sempre foi demais para aquela casa. A casa salmão onde havia uma família tentando se entender" (p. 60) -, sendo a ausência da personagem associada a características do lugar. E nesse caso temos novamente na obra de Carol o tema da arquitetura, mais uma vez atuando como um elemento que se confunde com a personalidade dos personagens e a partir do qual os mesmos são definidos ou confrontados:

(...) eu via as luzes da casa salmão acenderem e se apagarem, numa sequência que guardava a sua lógica muito particular (...) A casa está ainda pior, sobretudo porque é dia. A pintura desgastada, as infiltrações que não foram resolvidas, a piscina que desapareceu no meio do mato. (Bensimon, 2009, p. 132)

A decadência física da casa é associada à ausência de Antônia, relacionando de maneira metafórica a morte e a ruína. Isso ocorre também em uma passagem anterior, quando Bernardo se depara com a piscina da casa da amiga vazia - "A piscina é um buraco azul, sem sentido, vazia. (...) Piscina vazia é a coisa mais 
deprimente que pode existir, porque está sempre nos levantando a placa do algonão-vai-muito-bem" (p. 24).

O bar do Polaco, um dos cenários essenciais do livro, também acaba encontrando sua ruína devido a um projeto de revitalização da orla do lago, que acaba desapropriando o imóvel. E é justamente a visita que Bernardo faz ao local onde um dia existiu o bar que frequentava com Antônia que encerra o romance, como se um círculo tivesse se fechado: a morte de uma pessoa, a demolição de um local diretamente ligado a ela e Bernardo sobrevivendo a tudo isso:

(...) o céu e a água continuam naquela intersecção difusa e deprimente, que observo enquanto atravesso a rua em direção às ruínas do bar do Polaco. Elas ainda estão lá. E todo mundo sabe que estarão por anos, que teremos que conviver com esse esqueleto, uma vez que projetos para a orla costumam ser exatamente, e tão somente, projetos para a orla. O que aconteceu foi, na verdade, uma prova de força, penso ao colocar o primeiro pé nos restos do bar meio flutuante, o chão coberto de pedaços de concreto e metais enferrujados e ainda as marcas das antigas paredes. Tenho a sensação de andar sobre uma planta baixa de algum lugar ainda não construído. O fim se confunde muitas vezes com algo anterior ao começo. (Bensimon, 2009, p. 133)

Outra questão que chama atenção no livro é o modo como a autora trabalha a elaboração imagética. São várias as metáforas construídas por meio de criação de imagens e mesmo de referências diretas a elementos da visualidade, como neste trecho, ainda no primeiro capítulo:

[Antônia] dizia que o mundo era como um monte de gente recém-saída do oculista ainda sentindo o efeito do colírio-de-dilatar-pupilas: nos enche de mais luz do que podemos suportar e por isso ficamos sem ver nada de nada. Mais luz, mais escuridão. (Bensimon, 2009, p. 7).

Essa passagem, especificamente, é muito significativa quando colocada em uma perspectiva geral em relação ao tema do livro, tomado por uma atmosfera melancólica de perda, tristeza, escuridão e vazio ocasionados pela morte da personagem. E é possível, nesse sentido, lembrar de uma reflexão de Georges Didi-Huberman em A sobrevivência dos vaga-lumes (2011), quando ele afirma que "[n]ão vivemos em apenas um mundo, mas entre dois mundos pelo menos. O 
primeiro está inundado de luz, o segundo atravessado por lampejos" (DidiHuberman, 2011, p. 155).

Na mesma obra, Didi-Huberman pergunta: “[n]ão assume a imagem, em sua própria fragilidade, em sua intermitência de vaga-lume, a mesma potência, cada vez que ela nos mostra sua capacidade de reaparecer, de sobreviver?". E prossegue apontando que:

é preciso compreender a sobrevivência das imagens, sua imanência fundamental: nem seu nada, nem sua plenitude, nem sua origem antes de toda memória, nem seu horizonte após toda catástrofe. Mas sua própria ressurgêncía, seu recurso de desejo e de experiência no próprio vazio de nossas decisões mais imediatas, de nossa vida mais cotidiana. (Didi-Huberman, 2011, p. 128)

E a sobrevivência parece ser, de fato, uma questão central no romance de

Carol Bensimon. Em uma passagem do livro são citados alguns versos da música "Alive", da banda norte-americana Pearl Jam, entremeados aos pensamentos de Camilo, quando este nota que está sendo observado por algumas pessoas no bar do Polaco, concluindo que elas desaprovam o fato de ele estar ali pouco tempo depois da morte da irmã:

Não é legal ser visto num bar quando sua irmã morreu só há dois meses, porque, além de esperarem que você fique chorando trancado no quarto, também desaprovam o fato de você estar cercado de álcool, logo quando uma das desconfianças que as pessoas têm é de que ela estava tão bêbada que não pôde evitar sair voando ladeira abaixo e acabar esborrachada num poste Mas eu fico em silêncio. Tudo bem com você? Tudo legal. Pearl Jam com os baixos estourando. Is something wrong, she said. Well of course there is. You're still alive, she said. Tati pergunta se estou a fim de dar uma volta e eu digo que estou, afinal não tenho nada melhor para fazer (Bensimon, 2009, p. 32-33).

E, talvez, assim como canta o vocalista Eddie Vedder nos versos seguintes da canção - "Oh and I do deserve to be? / is that the question? / And if so, if so / Who answers? Who answers?" - o problema seja justamente o fato de que os vários personagens do romance, com exceção da protagonista ausente, estão vivos e, mais do que aceitar a morte, é preciso aprender que não há maneira menos difícil de lidar com o vazio de uma perda irreparável. 
É partir de um elemento externo e real (no caso a música da banda Pearl Jam) que se abre uma possibilidade de leitura de algumas nuances do livro. O mesmo ocorre no trecho em que Camilo, devastado pela morte de Antônia, se define como "um Axl Rose gordo sozinho num quarto de hotel, um Kurt Cobain na estufa com a arma que toca o céu da boca e, se os caras compensam um fracasso final com um passado brilhante, eu não" (p. 14). Em ambos os casos, a presença desses elementos se articula no sentido de criar sensibilidades e desdobramentos da história a partir da intimidade dos personagens que encaram a tarefa de lidar com suas perdas.

Em Sinuca embaixo d'água a questão da morte é um dos temas centrais, simbolizada no livro em vários momentos por meio da representação da impossibilidade do toque, do contato físico com a personagem ausente, o que fica explícito, por exemplo, na passagem já citada - "e eu não tenho a menor chance de tocar outra vez em Antônia" - e na epígrafe do romance, de autoria do músico norte-americano Johnny Thunders: "You can't put your arms around a memory". $\mathrm{E}$, mais do que um tema, a morte funciona como uma espécie de catalisador no livro de Bensimon. É a partir da morte da protagonista ausente que todo o enredo se cria e em torno dessa perda que a trama do livro se articula.

O livro mais recente de Carol, Todos nós adorávamos caubóis, parte de uma premissa bem menos trágica, entretanto, também passa por questões similares, relacionadas a modos distintos de desdobrar e caracterizar o universo íntimo de seus personagens, como procurarei analisar na próxima seção.

\section{3.}

\section{A dupla viagem de Todos nós adorávamos caubóis}

Lançado em 2013, Todos nós adorávamos caubóis se estrutura a partir de um deslocamento geográfico. Cora - a narradora do romance, que se desenvolve inteiramente com a narração em primeira pessoa - e Júlia, duas amigas que têm uma relação antiga e ambígua, embarcam em uma viagem de carro pelo interior do Rio Grande do Sul, colocando em prática um plano elaborado tempos antes, 
mas que tinha ficado em suspenso depois de uma briga que fez com que elas ficassem mais de cinco anos sem se falar. O livro se inicia justamente com o começo da viagem, que elas chamam de "Viagem sem planejamento", e que consistia basicamente em passar por pequenas cidades do interior do estado, conhecendo e descobrindo detalhes desses lugares, se deparando com cenários ainda não vistos e sobre os quais elas nada sabem.

Tudo o que fizemos foi tomar a BR-116 (...) Deixamos para trás as ruas suburbanas cujo início é marcado pela rodovia, que depois vão se perder em um parque industrial e nos casebres jogados em volta de um arroio, onde os cachorros vadios se arrastam e quase nunca latem, e seguimos, seguimos até a reta virar curva. Eu dirigia. Julia estava com os pés sobre o painel. Eu raramente podia olhar para ela. Quando ela não sabia a letra das músicas, cantarolava. "Tu mudou o cabelo", eu disse, olhando de relance para a franja dela. Julia respondeu: "Há mais ou menos dois anos, Cora". Nós rimos enquanto subíamos a serra. Isso foi o começo da nossa viagem. (Bensimon, 2013, p. 7)

Antônio Prado, Cambará do Sul, Minas do Camaquã e Bagé são algumas das cidades pelas quais Cora e Júlia passam em sua viagem. Não há nenhum objetivo definido nas visitas a essas cidades, que não apresentam nenhum atrativo turístico ou nada parecido. As personagens se dedicam apenas a andar pelas ruas, conhecendo um ou outro local que julgam que possa ser interessante, como pequenos museus, monumentos, vilas, trilhos de trem e lugares abandonados. A partir do contato com esses locais, percepções e sensações vão se formando, assim como vínculos entre Cora e Júlia e os cenários pelos quais elas transitam, que afetam as personagens de diferentes formas:

Perto dos trilhos, além das palmeiras mais compridas que eu já tinha visto, havia um casarão em pedaços coberto de grafite. Alguns garotos e garotas de vinte e poucos anos estavam posicionados em uma abertura, os pés balançando no ar, provavelmente na expectativa de que o sol se pusesse sobre o campo. Ainda levaria um certo tempo. Enquanto isso, eles contavam histórias e riam. $\mathrm{O}$ sul do estado era uma ruína que se recusava a ir completamente ao chão. Por mais estranho que possa parecer, eu me sentia solidária, e sobretudo confortável, no meio daquela decadência. (Bensimon, 2013, p. 145)

Vários estados interiores das duas personagens são evocados a partir de seu contato com os cenários exteriores que visitam e das associações e relações que se 
estruturam a partir da observação e do simples fato de estarem presentes nesses lugares:

\begin{abstract}
Andei até o cemitério. Julia estava entrando na casinha da administração. Achei sensato ficar longe, de modo que fiz o que todas as pessoas fazem em um lugar desses: primeiro, me senti um tanto desamparada e frágil e com prazo para terminar, olhando o conjunto dos túmulos que eram uma espécie de skyline da cidade dos mortos, não querendo imaginar o que acontecia, e sobretudo o que não acontecia, embaixo das minhas botas. A partir do que era preciso se distrair. A etapa seguinte consistia exatamente nisto, tirar os maus pensamentos da cabeça, o que se fazia caminhando, lendo a sucessão de lápides, analisando as fotografias ovais, espiando pelos vidros sujos dos mausoléus centenários, e, quando a segunda data menos a primeira dava algo menor que setenta, tentando imaginar o que diabos acontecera com o pobre sujeito para ter vivido assim tão pouco. Parece estranho, mas, depois do impacto inicial, acho que a morte dos outros fazia com que a gente pensasse menos em nossa própria morte, aquele silêncio, aquelas pedras, todos aqueles rostos congelados estavam no fundo dizendo que nós estávamos vivas, que íamos sair andando dali, ainda havia muito tempo para morrer. (Bensimon, 2013, p. 152-153)
\end{abstract}

Em entrevista ao site da Saraiva na época em que ainda estava escrevendo Todos nós adorávamos caubóis, Carol Bensimon fala sobre a importância dos cenários em seus livros, sublinhando a diferença entre este romance, que se passa em vários lugares desconhecidos para as protagonistas, e os livros anteriores, cujas tramas se desenvolvem em locações que guardam uma relação afetiva com os personagens que nelas transitam, como a casa de Alice em Pó de parede e o bar do Polaco em Sinuca embaixo d'água:

Acho que os lugares revelam muito sobre as personagens que neles orbitam e, ao mesmo tempo, escondem o que deve ficar escondido. (...) $\mathrm{O}$ livro que estou escrevendo se passa num espaço muito mais amplo, várias cidades, estradas, e a narradora está vendo tudo aquilo pela primeira vez, então o olhar é diferente, não há a sensação de conforto que certos espaços passam ao personagem, mas de deslumbramento, ou às vezes de incômodo. (Bensimon, 2012)

Muitos dos conflitos interiores da narradora são disparados a partir de seu contato com um mundo estranho exterior. Nesse movimento, há um desvelamento íntimo, uma ressignificação de sentimentos e um duplo confronto: é a partir da descoberta de locais desconhecidos que Cora tenta restaurar uma intimidade perdida consigo mesma e com Júlia. 
A influência desses espaços, portanto, vai além da descoberta e da contemplação. O olhar de Cora parece estar sempre voltado não propriamente para o exterior, mas para o efeito que esses cenários externos têm nela mesma e em Júlia. $\mathrm{O}$ modo como elas reagem às descobertas de paisagens estranhas, a curiosidade em entender determinados locais que parecem misteriosos, como a sede do Projeto Portal - uma construção encontrada pelas personagens, dois pavilhões que, como descobrem um pouco mais tarde, eram dedicados à “observação de luzes coloridas piscantes e conversas telepáticas com seres de outros planetas" - e o rejeito - um enorme espaço em Minas do Camaquã formado por "[t]udo que saía das minas e não era cobre (...) Pilhas e pilhas de pedra triturada vezes cento e cinquenta anos. (...) Um deserto feito pelo homem" - é uma espécie de fio condutor da tensão entre as duas, se desdobrando em situações que as aproximam ou afastam ao longo da narrativa.

Uma vez que o foco narrativo é em primeira pessoa, não temos acesso aos pensamentos de Júlia, apenas às impressões de Cora sobre as ações e reações da outra personagem. E, enquanto o olhar de Cora parece sempre mais focado em Júlia do que em qualquer outra coisa, o olhar de Júlia aparenta estar voltado muito para o que vem de fora, o que diz muito sobre a dinâmica da relação das personagens e pode ser notado, por exemplo, na seguinte passagem:

Dali dava para ver toda a cidade. Quase nada se mexia. Galos cantavam não se sabia onde ou por quê, as vagonetas expostas diante do Cine Rodeio sentiam saudades das do mundo. Atrás de nós, havia sobrado a estrutura envelhecida de um outdoor. (...) Ficamos um pouco em silêncio. Nós estávamos em uma parte estranha da cidade; além da estrutura do outdoor, havia no topo daquele morro uma estrela de metal presa a um suporte de uns cinco metros de altura, bem como certa torre livremente inspirada na arquitetura dos castelos medievais. Uma escada em caracol, cheia de buracos de ferrugem, corria pela parte externa da torre. (...) Fiquei olhando para Julia, Julia para a cidade, a cidade para os eucaliptos, e os eucaliptos por sua vez podiam estar olhando na direção da sua casa, isto é, para as distantes terras da Oceania. (Bensimon, 2013, p. 110-111)

Esse local específico, inclusive, a estrutura de outdoor abandonada, é um dos vários cenários do livro que estão presentes tanto no booktrailer como no álbum de fotos postado por Carol Bensimon, sobre o qual falei no início deste capítulo. No álbum existem alguns comentários de leitores que fazem observações 
como "vejo Cora e Júlia por essas ruazinhas" e essa situação é interessante no sentido de que, por meio do vídeo e das fotos, os leitores têm outro tipo de acesso aos cenários do romance, que são um elemento fundamental na narrativa.

Também no início deste capítulo falei sobre a playlist criada por Carol e disponibilizada na internet que acompanhou o lançamento do livro. A playlist traz músicas que de algum modo fazem parte do universo do livro, não necessariamente sendo citadas ao longo do romance, e sim tendo uma relação que é vislumbrada pela autora durante o processo de escrita, como ela explica no texto "Para escrever, aperte play" (2011b): "É bastante comum que certas músicas me ajudem a criar uma cena, e isso porque elas carregam consigo o tom exato que quero dar a ela (se fosse um filme, aquela seria a trilha etc)".

Algumas canções são citadas ao longo do livro, como no trecho que a narradora diz que em alguns trechos do caminho "colocávamos músicas antigas no som e cantávamos junto, No Doubt, Silverchair, Alanis Morissette antes da sua viagem para a Índia” (p.103), mas há, em certo ponto do livro, uma referência mais significativa em relação a uma das canções da playlist, quando a narradora evoca "The Rain Song"19 como uma possível trilha sonora para uma cena que se passa após um desentendimento que ocorre entre as duas protagonistas:

\begin{abstract}
Essa seria a parte em que "The Rain Song" tocaria de fundo, você me veria ainda sentada no banco por tempo suficiente para entender que eu estava sofrendo de verdade, era uma canção do Led Zeppelin, daquele álbum que eu e Julia tínhamos escutado tantas vezes no pensionato Maria Imaculada, algumas cenas em retrospecto tentariam dar conta da infinidade de situações que eu já guardava aquecidas na memória (...) Mas então teríamos que infelizmente voltar à realidade, para minha cara triste contemplando o chão, e, pouco tempo depois, como que respondendo ao momento mais grandioso da música, que chacoalha tudo lá pelos cinco minutos e retorna à calmaria sem maiores traumas, lá estou eu erguendo a cabeça não por algum traço de otimismo ou dignidade, mas porque acabo de ver faróis, os faróis de um carro, os faróis do meu carro cruzando o portão e depois sumindo. (Bensimon, 2013, p. 148)
\end{abstract}

A dinâmica impressa na cena é a de um filme, tanto pela alusão à visualidade - "você me veria ainda sentada no banco por tempo suficiente para entender que eu estava sofrendo de verdade" - como pela referência ao recurso da

\footnotetext{
${ }^{19}$ Disponível em: <https://www.youtube.com/watch?v=CxEu0QN6nzk>.
} 
trilha sonora - "Essa seria a parte em que The Rain Song tocaria de fundo" -, assim como a associação entre a ação e a música - "como que respondendo ao momento mais grandioso da música, que chacoalha tudo lá pelos cinco minutos e retorna à calmaria sem maiores traumas, lá estou eu erguendo a cabeça”.

Essa relação com o cinema, entretanto, não aparece de forma repentina dentro do romance. Em uma coluna intitulada "Pegando a estrada", Carol fala sobre essa filiação, contando que está escrevendo um romance e que "[n]ão querendo entrar nesse ou naquele detalhe da trama, o que é apropriado dizer agora é que ele deve se parecer com um road movie. Notem que eu estou usando o termo road movie, não road novel" (Bensimon, 2011c).

Algumas passagens do romance realmente têm um tom que alude a procedimentos cinematográficos, como a montagem, e um exemplo disso é a própria estrutura do livro, que não segue uma linearidade e parece, assim como as personagens, estar o tempo todo em movimento, deslocamentos no tempo e no espaço, de modo a contar a história pregressa das personagens na medida em que elas avançam em sua viagem.

Além disso, o romance tem uma forte ligação com produções visuais. O título, por exemplo, é uma referência a filmes de caubóis e velho oeste, que tanto Júlia como Cora adoram. A narradora se define como uma garota que "[a]ssistiu ao clipe de Alicia Silverstone e Liv Tyler barbarizando nas estradas mais ou menos umas duzentas vezes", fazendo referência ao clipe da música "Crazy", da banda Aerosmith, vídeo que fez um enorme sucesso nos anos 90, no qual duas personagens, interpretadas por essas atrizes, viajam sem rumo pela estrada, assim como as protagonistas do livro.

Em outra passagem, Cora e Júlia discutem o final do filme Thelma \& Louise (1991), que também é frequentemente citado por Bensimon em entrevistas como uma referência, por ser um road movie com protagonistas femininas, como quando a autora comenta algumas das ideias inicias do romance:

Sempre fui fã de narrativas de estrada. Me atrai a ideia de liberdade que vem com os deslocamentos, sobretudo quando esse deslocamento é muito mais importante do que propriamente chegar a um lugar determinado. (...) As garotas vieram 
naturalmente, porque elas são artigo raro nesse tipo de narrativa, salvo em Thelma \& Louise, o filme, e talvez mais uma ou outra exceção. A regra costuma ser: as mulheres ficam, os homens partem. Além disso, essas poucas mulheres que se deslocam, bem, elas são vistas como pessoas perdidas, não como aventureiras, independentes ou heroicas, como é o caso dos homens viajantes. Então eu quis colocar duas garotas em cena para romper com essa lógica. (Bensimon, 2013)

Mas existe uma complexidade relativa a essas duas personagens (e que, nas referências citadas, o clipe e o filme, aparece apenas como uma espécie de subtexto nunca confirmado): logo no início do livro, a narradora Cora, ao falar da viagem e de como ela estava acontecendo anos depois de planejada, comenta que ela e Júlia tinham sobrevivido a uma briga que continuava pairando sobre elas e esse desentendimento, acontecido ainda nos tempos de faculdade, está ligado à ambiguidade do relacionamento que havia alguns anos antes entre as duas personagens, que eram amigas, mas tiveram, em determinado momento, um envolvimento afetivo e sexual:

Então eu e Julia ficamos amigas e começamos a andar por aí e mais ou menos esquecemos de todo o resto dos colegas (...) Nós saíamos cada vez mais. Não convidávamos ninguém. Julia ainda não gostava de cerveja, mas começou a tomar batidas, o que queria dizer álcool de baixa qualidade com altas doses de leite condensado. Seus olhos ora se perdiam nas águas mal iluminadas do Guaíba, ora se concentravam em mim. Um dia, ela chegou mais perto e me deu um beijo. Então isso virou mais ou menos a norma: as duas bêbadas, no banco de trás do carro, em motéis que cobravam pouco por estadias de duas horas, nos banheiros sujos dos postos de gasolina. (Bensimon, 2013, p. 51)

Entretanto, o envolvimento entre elas sempre se constituiu como uma relação indefinida, com idas e vindas e sem delimitações muito nítidas - "De amantes secretas (...) eu e Julia tínhamos regredido à condição de melhores amigas, que às vezes, poucas vezes, passavam um tantinho da conta" (p. 69) devido à postura de Júlia diante do relacionamento das duas. Em certo ponto da narrativa, Cora se define como bissexual, mas não se restringe a isso, detalhando algumas nuances e especificidades de sua orientação:

Sim, eu me sentia atraída por garotas. Tecnicamente, eu era bissexual. Minha linha do tempo teria todos os indícios. (...) Mas eu disse bissexual. Garotas e alguns garotos. Ou, para ser mais exata: garoto. Garota. Garota. Garota. Garoto. Garota. Garota. Garoto. E daí seguindo usualmente essa proporção. Com os garotos, eu 
ficava por inércia. Com as garotas, por encantamento. Com os garotos, tudo transcorria como em um roteiro de comédia romântica para grande público (salvo que eu estava justamente fingindo o papel que me cabia). Com as garotas, tudo começava, continuava e acabava no mais puro melodrama. (Bensimon, 2013, p. 4546)

Alicia Lapointe, em artigo publicado no livro Critical Concepts in Queer Studies and Education (2016), ao discorrer sobre o uso do termo "postgay", considera a existência de um zeitgeist queer característico do século XXI. Acredito que essa seja uma chave interessante para a leitura do romance de Carol Bensimon, assim como alguns estudos no campo da psicologia que têm apontado para um fenômeno contemporâneo que vem sendo chamado de fluidez sexual ${ }^{20} \mathrm{e}$ se refere a comportamentos sexuais e afetivos que fogem dos rótulos tradicionais de heterossexualidade, homossexualidade e bissexualidade.

O livro Sexual fluidity: Understanding Women's Love and Desire (2008), de autoria da psicóloga Lisa M. Diamond, traz um estudo sobre o tema a partir de entrevistas feitas com 100 mulheres ao longo de 10 anos, que identifica justamente que esses rótulos não têm dado conta da variedade de comportamentos que foram identificados ao longo da pesquisa. A autora pondera que o modelo tradicional de orientação sexual tem se revelado impreciso nos dias atuais, afirmando que

A revised model has to balance the fact that women do appear to possess relatively stable overall patterns of sexual attraction with the fact that they nonetheless show variability in feelings and experiences over time and across situations. A model positing female sexual fluidity is the best solution. (Diamond, 2008, p.84)

Essa fluidez parece ser um ponto importante no conflito central de Todos nós adorávamos caubóis: se por um lado temos Cora e sua orientação "tecnicamente" bissexual - ou seja, fica a impressão de que ela não se sente totalmente à vontade com esse rótulo -, por outro lado, Júlia - que é definida a certa altura do livro pela amiga/namorada como "lésbica ocasional quando

\footnotetext{
${ }^{20}$ Carol Bensimon publicou no jornal Zero Hora, em 2014, um texto sobre esse assunto, intitulado "A cultura da não-exclusividade", abordando justamente a fluidez sexual como uma característica contemporânea. Disponível em: http://zh.clicrbs.com.br/rs/entretenimento/noticia/2014/04/carolbensimon-a-cultura-da-nao-exclusividade-4485475.html.
} 
ninguém está vendo" -, encontra dificuldade em reconhecer-se em um relacionamento homossexual, se esquivando tanto de uma definição como de situações que pudessem revelá-lo a outras pessoas:

Julia preferia me esconder (logo, sentia vergonha de mim). Retraçar as razões dessa vergonha era, nesse ponto, insignificante. Tanto fazia a forma como ela fora criada, e por quanto tempo teve que frequentar a igreja aos domingos, e se seu ideal romântico se formou e permaneceu inalterado desde a primeira Barbie e o primeiro Ken. Nada disso mudava o fato de que, para todos os efeitos, ainda que ela me empurrasse para o meio das suas pernas, cravasse as unhas em mim, gritasse, deitasse a cabeça na minha barriga depois, nós continuávamos sendo tão somente boas amigas. (Bensimon, 2013, p. 150)

Essa indefinição é responsável por imprimir um tom de ambiguidade não só na relação das personagens, mas também na narrativa em geral. Cora está sempre em dúvida em relação ao próximo acontecimento em relação a ela, Júlia e a viagem. É como se qualquer passo inexato pudesse colocar tudo - Cora e Júlia, a viagem, a narrativa - a perder. Ao mesmo tempo, é justamente a inexatidão que marca o percurso das personagens na "Viagem sem planejamento" e, uma vez que a trama do livro é construída em função dessa jornada, a natureza da narrativa está fundada em seu próprio movimento. Ao mesmo tempo em que as personagens estão na estrada, viajando sem obedecer a nenhum planejamento mais concreto, o enredo também corre de maneira imprevisível, não linear, seguindo apenas, no presente, o traçado da viagem e, no passado, a fluência da memória.

Existem, portanto, dois planos narrativos: o presente, no qual está acontecendo a viagem, e o passado, com as histórias pregressas das personagens. Esses dois planos se intercalam na narração de Cora e é interessante observar como se dá essa alternância. Ela não ocorre, por exemplo, como em Mãos de cavalo, de Daniel Galera, livro analisado no capítulo anterior e que intercala os planos em capítulos distintos. O movimento é diferente também do realizado em "A caixa", conto em que a mudança temporal é marcada não só pela divisão dos trechos em anos (“1991”, “2007”), como também por trocas de foco narrativo. Em Todos nós adorávamos caubóis, essa movimentação se dá de forma mais sutil; a passagem entre os planos acontece por meio das lembranças evocadas pela 
narradora, que são apresentadas embaralhadas as ações do presente da narrativa, como na passagem:

Ficamos um pouco em silêncio. Nós estávamos em uma parte estranha da cidade; além da estrutura do outdoor, havia no topo daquele morro uma estrela de metal presa a um suporte de uns cinco metros de altura, bem como certa torre livremente inspirada na arquitetura dos castelos medievais. Uma escada em caracol, cheia de buracos de ferrugem, corria pela parte externa da torre.

"Onde é que a gente falou sobre essa história dos lugares?"

"No carro. Depois no pensionato."

"Eu tava bêbada?"

"Completamente."

"Wild times", ela disse, alongando as sílabas ao máximo.

Wild times de verdade. Julia nua diante de mim sob uma luz azulada. Seus olhos se empenhavam em observar algum detalhe horrendo do quarto, depois ela ficava de pé e se movia com as pernas como coladas uma na outra, tentando esconder alguma coisa que sinceramente era perda de tempo tentar esconder, enquanto eu dizia algo do tipo-o que eu dizia? eu dizia me dá um gole?, tá tudo bem?, eu nunca achei que tu-

Eu voltava para Minas do Camaquã. (Bensimon, 2013, p. 110)

Quando Júlia fala sobre o passado, definindo aquele tempo como "wild times", a memória de Cora a transporta para vivências passadas - "Júlia nua diante de mim sob uma luz azulada" -, mas a própria narradora marca o retorno ao plano narrativo do presente, quando assinala "Eu voltava para Minas do Camaquã", como se indicasse um deslocamento espacial.

Um movimento parecido acontece ao final do livro quando, já depois do fim da viagem, Júlia vai visitar Cora em Paris. As duas estão em um bar quando Cora se deixa levar pela memória para outro plano temporal, recordando e narrando o dia no qual a amizade delas teria começado. Esse movimento se desdobra ao longo do próprio texto, sem marcação ou divisão externa: do bar em Paris somos conduzidos, pelas lembranças da narradora, à cozinha da casa de sua mãe em Porto Alegre, anos antes, na noite onde começa a história das duas protagonistas:

Ficava encarando Julia de vez em quando. Ela parecia estar se divertindo pra valer, balançava a cabeça e os fiozinhos da franja se agitavam, o quadril entendia a música com perfeição, duas ou três vezes ela ergueu os braços bem alto, eu estou dizendo que ela estava realmente curtindo adoidado, ao mesmo tempo era como se ela não estivesse ali, não de todo, então eu resolvi não estar também. Minha casa. A essas alturas, meu conceito de casa tinha se diluído, minha casa de antes se 
chamava agora por convenção de casa da minha mãe, era nessa casa que eu pensava, e tudo começava no escuro. Nas madrugadas da nossa rua, havia uivos de cachorro e às vezes grilos. Qualquer coisa além disso já nos punha em estado de alerta. Desci as escadas pé ante pé, entrei na cozinha, fui tateando o balcão até chegar na geladeira. Quando encontrei a garrafa dágua, todo o conjunto de luzes fluorescentes se acendeu.

"Oi", disse minha mãe. Ela estava parada na porta de camisola.

"Achei que tu tava dormindo."

"Eu acordei quando tu chegou. Vocês. Tem uma menina no teu quarto, Cora?" (Bensimon, 2013, p. 189)

Esse duplo movimento - o deslocamento físico da viagem e a não linearidade temporal - confere a Todos nós adorávamos caubóis uma estrutura inconstante, fazendo com que as ambiguidades e imprecisões mais íntimas das personagens transbordem também para um nível formal, interferindo não só no que é narrado, mas também no modo como esses acontecimentos são apresentados, criando uma atmosfera de incerteza que vai muito ao encontro da imprecisão da própria narrativa, uma história permeada de indeterminações e hesitações, e transcendendo, assim, uma simples representação dos conflitos por meio de ações e episódios.

Nesse sentido, a literatura de Carol se aproxima do conceito de Stimmung, que, segundo Hans Ulrich Gumbrecht (2014), estaria relacionado a atmosferas e nuances específicas que não são captadas facilmente pela linguagem. De acordo com Gumbrecht:

Ler com atenção voltada ao Stimmung sempre significa prestar atenção à dimensão textual das formas que nos envolvem, que envolvem nossos corpos, enquanto realidade física - algo que consegue catalisar sensações interiores sem que questões de representação estejam necessariamente envolvidas. (Gumbrecht, 2014, p. 14)

Gumbrecht afirma ainda que, ao concentrar-se no Stimmung, "o objetivo é seguir as configurações da atmosfera e do ambiente, de modo a encontrar, em formas intensas e íntimas, a alteridade” (2004, p. 23). É possível, a partir disso, desdobrar mais uma possibilidade de leitura em Todos nós adorávamos caubóis, ligada, principalmente, à impermanência das atmosferas emanadas e construídas pelo livro, seja por meio da própria estruturação da relação dos personagens, das 
paisagens e do movimento narrativo ou de como esses elementos estão diretamente relacionados ao universo íntimo de Cora e Júlia.

Acredito que, por meio das análises aqui empreendidas, tenha sido possível perceber como existe, na obra de Carol Bensimon, um estilo que se delineia desde o seu primeiro livro no sentido de explorar as relações entre personagens e espaços, interior e exterior, intimidade e externalidade, seja por meio da arquitetura ou das paisagens geográficas.

É claro que estamos falando de uma autora jovem, com apenas três livros de ficção publicados, e fazer qualquer afirmação mais definitiva é um risco, pois a qualquer momento ela pode lançar novas publicações que inaugurem uma estética completamente distinta em sua obra, transformando seus primeiros livros em experiências que apenas fundamentaram tendências que podem vir a transformar radicalmente sua escrita.

Um novo livro de Carol Bensimon, inclusive, está previsto para o segundo semestre de 2017, e possivelmente será lançado poucos meses após a defesa desta tese. Entretanto, pelo que a autora vem relatando sobre o novo romance em entrevistas $^{21}$, a narrativa possivelmente vai voltar a lidar com algumas das questões levantadas nessa análise.

\footnotetext{
21 "No livro que estou escrevendo, o cenário é rural, com uma natureza impressionante (norte da Califórnia), mas a gente vê o tempo inteiro lá um culto ao selvagem misturado a uma domesticação extrema desse espaço. (...) O que dá pra dizer, de qualquer forma, é que eu gosto de estar numa conexão bem forte com a paisagem". Disponível em: <http://jconline.ne10.uol.com.br/canal/cultura/literatura/noticia/2016/08/25/carol-bensimon-falasobre-mulheres-na-literatura-e-seu-proximo-livro-250049.php>.
} 


\section{4 \\ Uma espécie de emersão}

Definir e desdobrar um conceito: essa foi a intenção dessa tese. No caso, o conceito surgido a partir da ideia de realismo íntimo e suas expressões e possibilidades dentro de um recorte específico da prosa de ficção brasileira contemporânea. Trabalhei com a hipótese de que dentro dessa tendência existe um duplo movimento: os cenários e referências exteriores atuam, ao mesmo tempo, como reflexo interior e elemento constituidor e revelador do universo íntimo dos personagens. E é justamente essa movimentação em duas vias que caracteriza o realismo íntimo e o difere de outras tendências dos novos realismos, conforme vêm sendo delimitados e conceituados. Esse, portanto, seria o conceito de realismo íntimo a partir do termo usado por Karl Erik Schøllhammer e da minha leitura dos autores aqui analisados.

Tendo como base várias ideias relacionadas a questões como a presença do real na arte e na literatura, a tradição realista na literatura contemporânea, os retornos realistas e naturalistas na literatura brasileira e suas leituras na contemporaneidade, procurei analisar a obra de Daniel Galera e Carol Bensimon buscando possibilidades intimistas de representação da interioridade e construção dos mundos ficcionais, investigando de que forma isso se relacionava, simultaneamente, com a ambientação das tramas e a elaboração interior dos personagens.

A intenção foi, basicamente, trazer leituras dos textos a partir das quais fosse possível identificar e compreender esse duplo movimento do realismo íntimo; porém, acredito que a análise ocasionalmente tenha também se estendido para outras questões sugeridas pelos livros - o que, no meu entendimento, é apenas a consequência de se optar por uma leitura mais livre do corpus - e, em alguns momentos, conjugadas às leituras, foram trazidas ideias de teóricos contemporâneos que atuaram no sentido de iluminar e expandir possíveis interpretações e estratégias. 
Desse modo, considero que a tese se desenvolveu a partir de uma base teórica essencialmente (mas não só) historiográfica e de uma análise intensamente envolvida no texto literário, que, em alguns momentos, abre brechas para outras abordagens e caminhos, alguns próximos à teoria da literatura e da cultura e outros encostados em questões ligadas à filosofia.

Este último movimento se constitui então como uma espécie de emersão, uma maneira de terminar esse percurso. E, depois de dedicar a maior parte das páginas às ideias e fenômenos, ou seja, aos textos literários em si, acredito que seja o momento de falar um pouco mais sobre o conceito que veio permeando este texto, conceito esse que foi usado como forma de mediar a relação entre a ideia de realismo íntimo e os tão específicos mundos interiores da intimidade construídos por esses autores em seus livros.

Conforme definição apresentada ainda no início do trabalho, a realidade, pura e simples, estaria relacionada ao que existe fora ou independente da mente humana. E muito da literatura realista - principalmente no passado, mas também em algumas manifestações do presente - se dedica a recriar um mundo material e concreto a partir de um detalhamento focado principalmente no exterior.

Mas a realidade residiria apenas no que existe de concreto fora do indivíduo? É apenas a partir da recriação de um mundo material que se produz verossimilhança? Acredito que não - e é aí que entra a subjetividade e o modo peculiar por meio do qual o real se apresenta nesses livros: no que aqui chamo de realismo íntimo, eu diria que ela se mostra por meio de um reflexo, que cria o exterior, e, por meio dessa criação, define um personagem verossímil por meio de seu mundo interior, confirmando, ao mesmo tempo, a verossimilhança do mundo através da subjetividade desses mesmos personagens.

Acredito que tenha sido possível mostrar e confirmar isso ao longo das páginas anteriores quando, por exemplo, vimos que Galera ensaia uma figuração do mundo em seus primeiros livros, principalmente por meio de referências culturais e geográficas, mas logo investe em movimentos mais complexos, como em Mãos de cavalo, deslocando um personagem para o seu passado, tanto em uma perspectiva da memória quanto da presença física - e, nesse caso, um 
deslocamento é consequência do outro -, revelando os embates de Hermano consigo mesmo e com o mundo por meio da intensa presença da representação dos limites físicos e de uma aproximação entre personagem, mundo e leitores realizada por meio da construção de visualidades subjetivas do protagonista.

Já em Barba ensopada de sangue, o movimento ocorre de forma ainda mais intrincada, quando o mundo ficcional é desvelado para os leitores a partir da subjetividade do protagonista, que descobrem, reconhecem e desconhecem os lugares de Garopaba, em um movimento que consegue imprimir na narrativa não só a ambientação física da cidade, mas também vários aspectos inerentes à passagem do tempo e o modo como ela é experienciada pelos personagens. E, devido à doença neurológica do protagonista que o torna incapaz de reconhecer rostos, ficamos, assim como ele, "cegos" para as fisionomias dos outros personagens, o que nos coloca em uma posição ainda mais entranhada nas menores singularidades das relações do "nadador" com os outros e com o mundo.

Por fim, em Meia noite e vinte, a construção da intimidade é realizada muito a partir das relações dos personagens com a tecnologia, por meio do que eles escolhem, por exemplo, publicizar através da internet, como a reação de Aurora à morte de Andrei, ou, em outros momentos, devido a um desvelamento involuntário de detalhes da vida íntima desses indivíduos, como o aplicativo que, após a morte de Andrei, revela hábitos secretos do personagem para Emiliano.

Creio que também tenha sido possível identificar essa dupla movimentação entre interioridade e exterioridade na obra de Carol Bensimon, principalmente por meio da análise das relações que a autora constrói entre a arquitetura exterior do mundo e a estrutura interior dos personagens em Pó de parede, através, por exemplo, dos vários papéis que os cenários desempenham em "Capitão capivara" e a função figurativa e referencial da casa modernista de Alice, em "A caixa", que, ao mesmo tempo, projeta e desvela significações inerentes ao mundo interior e íntimo da personagem.

De modo similar, foi possível verificar como todos os mundos e referências exteriores dos personagens de Sinuca embaixo d'água - e podemos pensar tanto nos lugares como nos objetos e canções, por exemplo - representam e, ao mesmo 
tempo, são representados pela ausência de Antônia, a protagonista ausente, causa e consequência de praticamente toda a ação, reação e contemplação que se desenrola no romance.

Em um movimento mais amplo e multifacetado, a dupla viagem de Todos nós adorávamos caubóis também figura como expoente dessa dinâmica, ao trabalhar paisagens, deslocamentos geográficos e referências musicais e visuais em uma perspectiva combinada à intimidade das personagens, principalmente a narradora, como sentimentos, sensações, relacionamentos, memória e sexualidade, o que faz com que a trama esteja fundada em um movimento que se desdobra de modos distintos.

Existem muitas nuances dessas obras relacionadas ao realismo íntimo, como procurei salientar ao longo da tese, mas é claro que outras várias chaves de leitura também são possíveis. Daniel Galera, por exemplo, já foi lido em outros trabalhos a partir de uma perspectiva relacionada a sua atuação como escritor na internet e no mercado literário, enquanto a obra de Carol Bensimon tem sido encarada em outros estudos a partir de uma abordagem relacionada mais estritamente à escrita feminina.

Talvez seja necessário, portanto, salientar que os exercícios de análise aqui empreendidos se situam dentro de possibilidades que estão inevitavelmente ligadas à minha própria interioridade. São escolhas teóricas, historiográficas, estéticas e analíticas que, em grande medida, estão ligadas também ao meu percurso pessoal, ao modo como tento ler e entender o mundo e, consequentemente, ao meu próprio universo íntimo.

E até por esse motivo é difícil encerrar esse trabalho. Sempre resta a sensação de que ainda existe algo que não foi traduzido em palavras. Impressões, leituras, desdobramentos e possibilidades que subsistem em um plano inalcançável para a escrita, seja ela literária, acadêmica ou de qualquer outro tipo. Elementos que habitam mundos interiores que resistem à figuração, que se escondem em uma camada que se contrapõe a qualquer tipo de representação, estejam eles refletidos em uma exterioridade ou não. 
Entretanto, espero que alguns lampejos tenham sido capazes de iluminar os mergulhos que propus ao longo dessas páginas. Por mais que o mundo não se dobre facilmente a interpretações, é o desafio das tentativas que, de algum modo, nos move adiante. Por isso arriscar. E para isso é necessário entender que existe o momento de se preparar, o momento de mergulhar, o momento de respirar e o momento de colocar, mesmo que provisoriamente, um ponto final. 


\section{Referências Bibliográficas}

ABBAGNANO, N. Dicionário de Filosofia. São Paulo: Martins Fontes, 2007.

ARISTÓTELES. Poética. Porto Alegre: Globo, 1966.

BACHELARD, G. A poética do espaço. São Paulo: Martins Fontes, 2008.

BARTHES, R. "O efeito do real". In: Rumor da língua. São Paulo: Martins Fontes, 1981.

A Câmara Clara. Rio de Janeiro: Nova Fronteira, 1984.

BENSIMON, C. A personagem ausente na narrativa literária. Porto Alegre, 2008. Dissertação (Mestrado em Escrita Criativa) - Departamento de Letras, PUC-RS.

Pó de parede. Porto Alegre: Não Editora, 2008.

Sinuca embaixo d'água. São Paulo: Companhia das Letras, 2009.

Todos nós adorávamos caubóis. São Paulo: Companhia das Letras, 2013.

"Novo livro de Carol Bensimon, terá elementos de road novel". Entrevista concedida ao site Saraiva Conteúdo em 09 abr. 2012. Disponível em: <http://www.saraivaconteudo.com.br/Entrevistas/Post/44980>. Acesso em: 10 set. 2016.

Entrevista concedida à revista Trip em 08 out. 2013. Disponível em: <http://revistatrip.uol.com.br/tpm/carol-bensimon>. Acesso em: 15 jan. 2017.

. "Isso realmente aconteceu assim?" (2011a). Disponível em: $<$ http://historico.blogdacompanhia.com.br/2011/05/isso-realmente-aconteceuassim/>. Acesso em: 10 set. 2016.

"Para escrever, aperte play" (2011b). Disponível em: <http://historico.blogdacompanhia.com.br/2011/09/para-escrever-aperte-play/>. Acesso em: 10 set. 2016. 
BENSIMON, C. "Pegando a estrada" (2011c). Disponível em: <http://historico.blogdacompanhia.com.br/2011/11/pegando-a-estrada/>. Acesso em: 15 jan. 2017.

BROOKS, P. Realist Vision. New Haven: Yale University Press, 2005.

CALLE, S. Prenez soin de vous. Paris: Actes Sud, 2007.

COMPAGNON, A. O demônio da teoria - literatura e senso comum. Belo Horizonte: UFMG, 1999.

COOKE, J. (Org.). Scenes of Intimacy: Reading, Writing and Theorizing Contemporary Literature. Londres: Bloomsbury, 2013

CORTÁZAR, J. Valise de cronópio. São Paulo: Perspectiva, 2008.

DIAMOND, L. M. Sexual fluidity: Understanding Women's Love and Desire. Cambridge, MA: Harvard University Press, 2008.

DIDI-HUBERMAN, G. A sobrevivência dos vagalumes. Belo Horizonte: Editora da UFMG, 2011.

FIGUEIREDO, V. L. F. de. "Entre o texto e a imagem: a literatura equilibrista". In: OLINTO, H. K.; SCHOLLHAMMER, K. E. (Org.). Literatura e Criatividade. Rio de Janeiro:7 Letras, 2012.

"Encenação da realidade: fim ou apogeu da ficção?". Matrizes, a. 3, n. 1, ago/dez 2009. p. 131-143.

FOSTER, H. The return of the real. Londres: MIT Press, 1995.

GALERA, D. Dentes guardados. Porto Alegre: Livros do Mal, 2004.

2007.

Até o dia em que o cão morreu. São Paulo: Companhia das Letras, Mãos de cavalo. São Paulo: Companhia das Letras, 2006.

Barba ensopada de sangue. São Paulo: Companhia das Letras, 2012.

. Entrevista concedida ao jornal Expresso. 2014. Disponível em: <http://bibliotecariodebabel.com/entrevistas/papagaio-pousado-no-ombro/>. Acesso em: 27 nov. 2016. 
GALERA, D. Meia noite e vinte. São Paulo: Companhia das Letras, 2016.

Rancho Carne. Disponível em: <http://ranchocarne.tumblr.com/>. Acesso em: 15 jan. 2017.

_. Entrevista no projeto Segundas Intenções, promovido pela Biblioteca de São Paulo, em 2013. Disponível em: $<$ https://www.youtube.com/watch? $\mathrm{v}=$ Fj5OENcsonY\&t=1244s $>\quad($ parte 1$)$ e $<$ https://www.youtube.com/watch? $\mathrm{v}=\mathrm{Z1XO4a0Ya1A>} \mathrm{(parte} \mathrm{2).} \mathrm{Acesso} \mathrm{em:} 06$ jul. 2016.

GOMES, R. C. "Espectros e herdeiros da nação". In: OLINTO, H.; SCHØLLHAMMER, K. (Orgs.). Cenários contemporâneos da escrita. Rio de Janeiro: 7 Letras, 2013.

GUMBRECHT, H. U. Atmosfera, ambiência, Stimmung. Rio de Janeiro: Editora PUC-Rio, 2014.

HALL, S. A identidade cultural na Pós-Modernidade. Rio de Janeiro: DP\&A, 1999.

JAGUARIBE, B. "Ficções do real: notas sobre as estéticas do realismo e pedagogias do olhar na América Latina contemporânea". Ciberlegenda, n. 23, v. 1,2010 .

KIRNER, C. Realidade Virtual e Aumentada - Definições. Disponível em: <http://www.ckirner.com/realidadevirtual/?DEFINI\%C7\%D5ES>. Acesso em: 27 nov. 2016.

LAPOINTE, A. "Postgay". In: Critical Concepts in Queer Studies and Education: an international guide for the twenty-first century. Nova York: Palgrave Macmillian, 2016.

MCEWAN, I. Enclausurado. São Paulo: Companhia das Letras, 2016.

PELLEGRINI, T. "Realismo: postura e método". Letras de Hoje. Porto Alegre. n. 4, dez. 2007.

SANTIAGO, S. Vale quanto pesa. Rio de Janeiro: Paz e Terra, 1982.

SCHOLLHAMMER, K. E. Ficção brasileira contemporânea. Rio de Janeiro: Civilização Brasileira, 2010.

Realismo afetivo: evocar realismo além da representação. Estudos de Literatura Brasileira Contemporânea, v. 39, p. 129-148, 2012. 
SCHOLLHAMMER, K. E. "Barbas de molho". Cult, n. 174; 2012. Disponível em: <http://revistacult.uol.com.br/home/2012/11/barbas-de-molho/>. Acesso em: 27 nov. 2016.

"Para uma crítica do realismo traumático". Soletras. n. 23, 30 out., 2012. Disponível em: <http://www.e-publicacoes.uerj.br/index.php/soletras/ article/view/>. Acesso em: 10 abr. 2016.

"Crítico fala sobre realismo e violência nas artes brasileiras". O Globo.

Disponível em: <http://blogs.oglobo.globo.com/prosa/post/critico-fala-sobrerealismo-violencia-nas-artes-brasileiras-525294.html>. Acesso em: 07 fev. 2017.

SONTAG, S. Sobre a fotografia. São Paulo: Companhia das Letras, 2007.

SUSSEKÏND, F. Tal Brasil, qual romance?, uma ideologia estética e sua história: o naturalismo. Rio de Janeiro: Achiamé, 1984.

SWAREK, M. The Augmented Reality Korean Unification Project (2011). Disponível em: <https://koreanunificationproject.wordpress.com/>. Acesso em: Acesso em: 10 abr. 2016.

TONANI, P. "A volta da realidade das margens". Estudos de Literatura Brasileira Contemporânea, v. 39, p. 57-75, 2012.

"Passageiro do fim do dia, de Rubens Figueiredo: um olhar sobre o naturalismo". O futuro pelo retrovisor: inquietações da literatura brasileira contemporânea. Rio de Janeiro: Rocco, 2013.

WOOD, J. Como funciona a ficção. São Paulo: Cosac Naify, 2012.

"Human, All Too Inhuman - on the formation of a new genre: hysterical realism". New Republic. 2000. Disponível em: <https://newrepublic. com/article/61361/human-inhuman>. Acesso em: 10 abr. 2016. 